\title{
Thermo-tectonic development of the Wandel Sea Basin, North Greenland
}

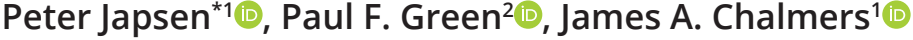 \\ ${ }^{1}$ Geological Survey of Denmark and Greenland (GEUS), Copenhagen, Denmark, ${ }^{2}$ Geotrack International, Brunswick West, Victoria, Australia
}

\begin{abstract}
The Carboniferous-Palaeogene Wandel Sea Basin of eastern North Greenland (north of $80^{\circ} \mathrm{N}$, east of $40^{\circ} \mathrm{W}$ ) is an important piece in the puzzle of Arctic geology. It is particularly important for understanding how the Paleocene-Eocene convergence between Greenland, the Canadian Arctic and Svalbard relates to the compressional tectonics in the High Arctic, collectively known as the Eurekan Orogeny. In this study, we present apatite fission-track analysis (AFTA) data and review published vitrinite reflectance data combined with observations from the stratigraphic record to place firmer constraints on the timing of key tectonic events. This research study reveals a long history of episodic burial and exhumation since the collapse of the Palaeozoic fold belts in Greenland. Our results define pre-Cenozoic exhumation episodes in early Permian, Late Triassic, Late Jurassic and mid-Cretaceous times, each involving the removal of kilometre-scale sedimentary covers. Mid-Paleocene exhumation defines the timing of compression along the major fault zones during the first stage of the Eurekan Orogeny, after the onset of sea-floor spreading west of Greenland. Regional exhumation that began at the end of the Eocene led to the removal of most of a kilometre-thick cover that had accumulated during Eocene subsidence and involved a major reverse movement along the Harder Fjord Fault Zone, northern Peary Land. These events took place after the end of sea-floor spreading west of Greenland, and thus, represent post-Eurekan tectonics. Mid-late Miocene exhumation is most likely a consequence of uplift and incision across most of the Wandel Sea Basin study area. The preserved sedimentary sequences of the Wandel Sea Basin represent remnants of thicker strata that likely extended substantially beyond the present-day outline of the basin. We find that the present-day outline of the basin with scattered sedimentary outliers is primarily the result of fault inversion during Eurekan compression followed by deposition and removal of a kilometre-thick overburden.
\end{abstract}

\section{Introduction}

The Carboniferous-Palaeogene Wandel Sea Basin in eastern North Greenland is an important piece in the larger puzzle of Arctic geology (Figs. 1, 2). The basin records sedimentation along the western margin of Svalbard and the Barents Sea, on the north-western flank of the Danmarkshavn Basin (offshore North-East Greenland) and south of the Cenozoic sea-floor spreading in the Arctic Ocean. Several aspects of the development of the Wandel Sea Basin remain controversial, in particular, the timing of a major, compressional tectonic event that affected the basin in post-Cretaceous times is much debated. Did it happen during a comparatively brief period of time around the

\author{
*Correspondence: pj@geus.dk \\ Received: 15 May 2019 \\ Accepted: 25 June 2020 \\ Published: 26 April 2021
}

Keywords: Eurekan Orogeny, uplift, exhumation, Svalbard, Sverdrup Basin

\section{Abbreviations: \\ AFTA: apatite fission-track analysis a.s.I.: above sea level CAl: colour alteration index CTB: Central Tertiary Basin EGFZ: East Greenland Fracture Zone HALIP: High Arctic Large Igneous Province HFFZ: Harder Fjord Fault Zone KCTZ: Kap Cannon Thrust Zone TLFZ: Trolle Land Fault Zone VR: vitrinite reflectance}

GEUS Bulletin is an open access, peerreviewed journal published by the Geological Survey of Denmark and Greenland (GEUS). This article is distributed under a CC-BY 4.0 licence, permitting free redistribution, and reproduction for any purpose, even commercial, provided proper citation of the original work. Author(s) retain copyright.

Edited by: Catherine Jex (GEUS, Denmark)

Reviewed by: Andy Carter (Birkbeck, University of London, UK), Eckart Håkansson (The University of Western Australia, Australia)

Funding: See page 41

Competing interests: 41

Additional files: See page 41 


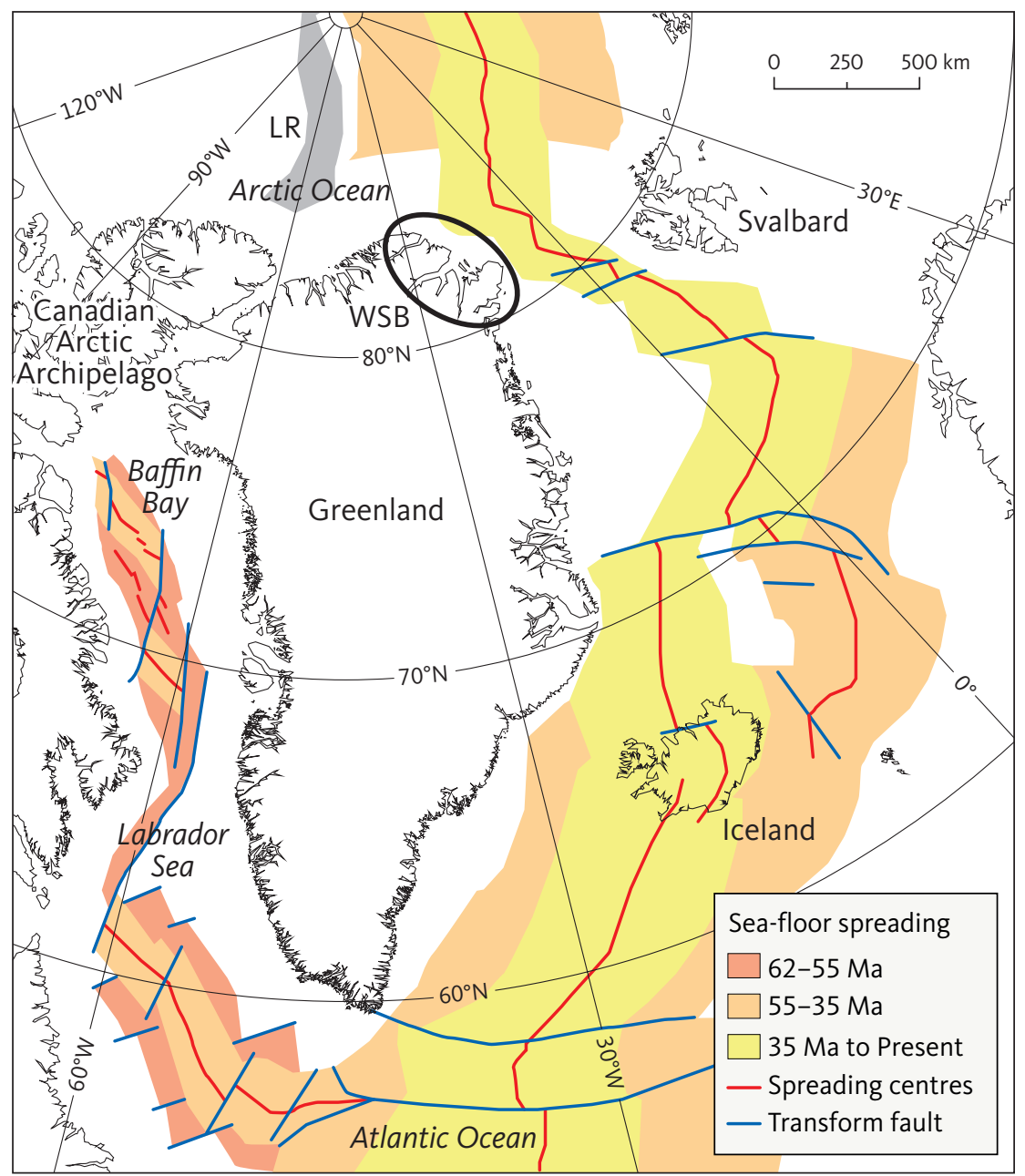

Fig. 1 Cenozoic sea-floor spreading in the northern North Atlantic area. Sea-floor spreading between North America and Greenland (62-55 Ma) caused the first stage of the Eurekan Orogeny. During this time, Greenland moved together with Europe. Spreading between Europe and Greenland (55-35 Ma) resulted in the second stage of the Eurekan Orogeny. During this time, North America, Greenland and Europe moved as separate plates. Seafloor spreading ceased west of Greenland (at c. $35 \mathrm{Ma}$ ) after which Greenland moved together with North America and the Eurekan Orogeny ended. The Danmarkshavn Basin is located off NorthEast Greenland between 76 and $82^{\circ} \mathrm{N}$. LR: Lomonosov Ridge. WSB: Wandel Sea Basin. Modified from Brozena et al. (2003), Oakey \& Chalmers (2012) and Gaina et al. (2017).

Cretaceous-Palaeogene boundary (Håkansson \& Pedersen 1982, 2001, 2015), during the Eocene (von Gosen \& Piepjohn 2003), during the late Paleocene-early Eocene (Døssing et al. 2010; Svennevig et al. 2016) or during the Late Cretaceous-Paleocene (Guarnieri 2015)?

Insights into the development of the Wandel Sea Basin are thus important for providing a better understanding of the relationship between (1) the mid-Paleocene to Eocene movement of Greenland relative to both North America (Oakey \& Chalmers 2012) and Eurasia (Gaina et al. 2017) and (2) the Palaeogene basin formation and compressional tectonics in the Wandel Sea Basin (the Kronprins Christian Land Orogeny; Håkansson \& Pedersen 2001, 2015) and in the neighbouring Carboniferous-Palaeogene basins in Canada (the Eurekan Orogeny; Okulitch \& Trettin 1991; Embry \& Beauchamp 2019) and on Svalbard (the West Spitsbergen Fold Belt; Steel et al. 1985; Dallmann et al. 1993; Dallmann 2015; Jones et al. 2017).

It is widely accepted that these tectonic events, which we refer to collectively as the Eurekan Orogeny, record the Palaeogene convergence between Greenland, the Canadian Arctic and Svalbard (De Paor et al. 1989; Ricketts 1994; Harrison 2008; Oakey \& Chalmers 2012;
Dallmann 2015; Gion et al. 2017; Jones et al. 2017; Embry \& Beauchamp 2019). Others restrict the term Eurekan Orogeny to the time span in the Eocene during which Greenland was part of a separate plate that was able to move independently with respect to both North America and Europe (e.g. Piepjohn et al. 2016; Tessensohn \& Piepjohn 2000). This definition, however, fails to include the deformations caused by the movement of Greenland during the late Paleocene.

The presence of many isolated occurrences of sedimentary strata has been suggested to represent at least 20 late Permian to Mesozoic pull-apart basins formed in response to episodes of combined transtension and transpression along the plate boundary between North Greenland and Svalbard (Håkansson \& Pedersen 2015). However, the possibility that these sub-basins may have been connected by substantial sedimentary covers that have since been removed by erosion has attracted little attention with some exceptions (Stemmerik et al. 1998; Pedersen et al. 2018). Another unresolved issue is an enigmatic event that affected the north coast of Kronprins Christian Land, in which Upper Cretaceous rocks reached extremely high vitrinite reflectance (VR) levels of 7-10\% (Håkansson et al. 1994). 


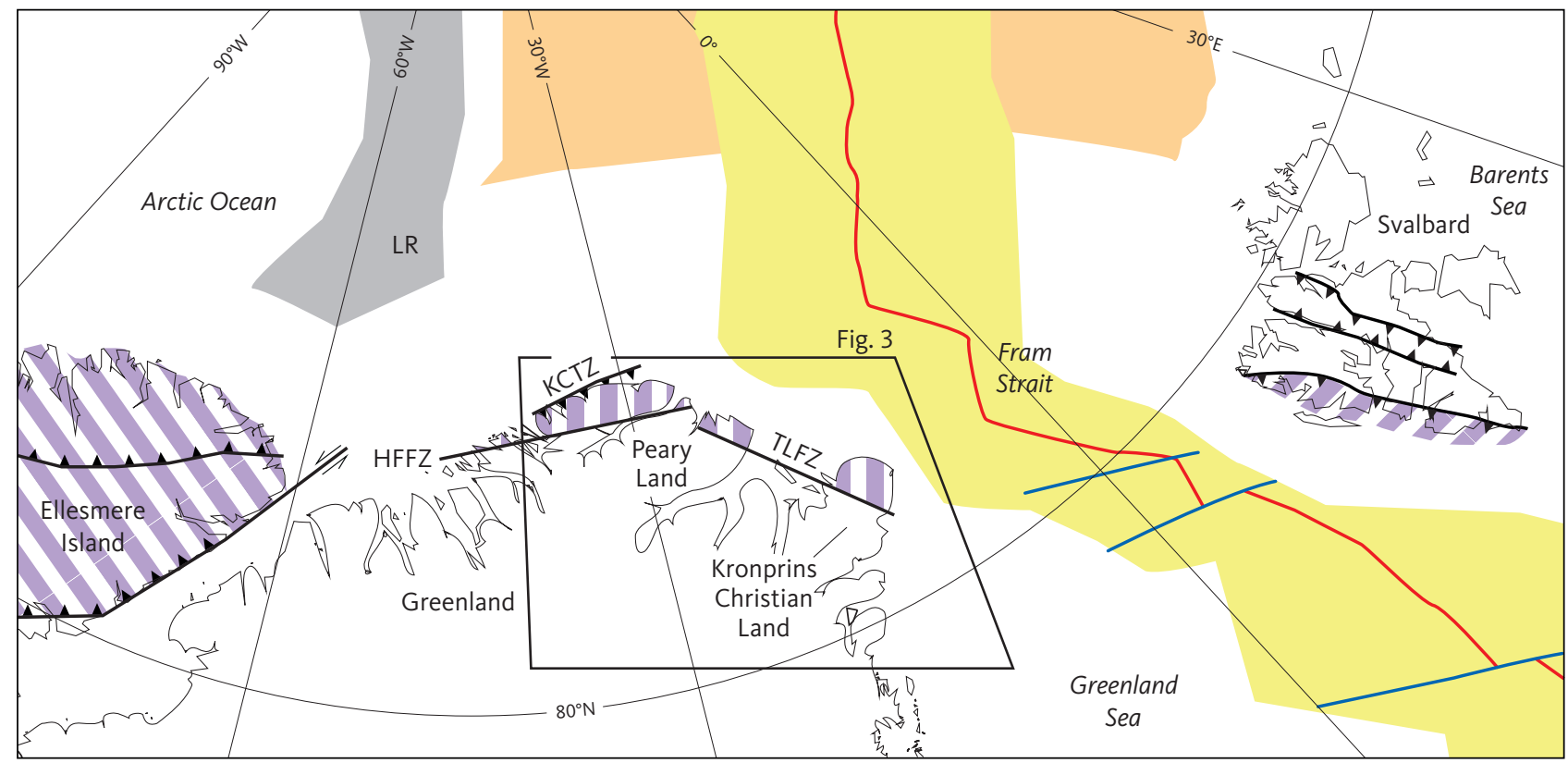

$\leftrightharpoons$ Strike-slip fault

^ـ Thrust zone Fault zone

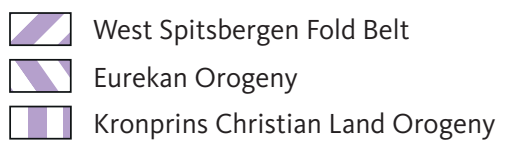

0

$500 \mathrm{~km}$

Fig. 2 Outline of the High Arctic adjacent to North Greenland. Extent of Kronprins Christian Land Orogeny according to Håkansson \& Pedersen (2001) and this study. LR: Lomonosov Ridge. Detail of Fig. 1 with additions from von Gosen \& Piepjohn (2003), Oakey \& Chalmers (2012) and Piepjohn et al. (2016).

In this study, we present new apatite fission-track analysis (AFTA ${ }^{\circledR}$ ) data from northern and eastern Greenland, which are focussed on the Wandel Sea Basin. These data shed light on the thermal and tectonic history of the region, both prior to and after the compressional tectonics that affected the Wandel Sea Basin in Palaeogene times. We combine thermal history interpretations from AFTA data in 52 outcrop samples (of which 46 are from north of $79^{\circ} \mathrm{N}$ ) with published VR data (Håkansson et al. 1994; Paech \& Estrada 2018; Pedersen et al. 2018) to provide insights into the tectonic development of the region. AFTA data define the timing and magnitude of key palaeothermal episodes - times at which rocks cooled from higher temperatures compared with present-day values - while VR data provide independent determination of maximum post-depositional palaeotemperatures. We relate the thermal history solutions from AFTA and VR data to former depths of burial and corresponding amounts of exhumation and produce a synthesis of late Palaeozoic to Cenozoic thermo-tectonic events in the region. We integrate these results with observations from the geological record (Håkansson \& Pedersen 2015; Svennevig et al. 2016, 2017, 2018; Alsen et al. 2018; Hovikoski et al. 2018; Paech \& Estrada 2018; Pedersen et al. 2018; Piasecki et al. 2018; Bjerager et al. 2019). Finally, we compare the results of this study with a companion study of North-East Greenland (Japsen et al. in press) and set the results in a regional context.

\section{Geological setting}

The Wandel Sea Basin occupies a broad, partially submerged or ice-covered depression centred around the Wandel Sea (north of $80^{\circ} \mathrm{N}$, east of $40^{\circ} \mathrm{W}$; Figs. 3 and 4; Dawes \& Soper 1973; Dawes 1976; Håkansson \& Pedersen 1982, 2001, 2015; Håkansson \& Stemmerik 1989; Stemmerik et al. 1998). The basin is located between the Caledonian Fold Belt along the east coast of Greenland and the Ellesmerian Fold Belt along the north coast (Fig. 1; Higgins et al. 2000). The main deformations took place during the Silurian and the early Carboniferous (Henriksen et al. 2009). The Wandel Sea Basin is the northernmost of a series of fault-bounded late Palaeozoic - early Palaeogene basins exposed along the eastern and northern margin of Greenland (Stemmerik et al. 1998). The basin contains sediments with a cumulative thickness of $>15 \mathrm{~km}$, resting unconformably on Precambrian to Silurian rocks (Fig. 5; Surlyk 1991; Håkansson \& Pedersen 2015). Upper Carboniferous - Triassic sediments accumulated in a system of grabens and half-grabens referred to as the North Greenland - Svalbard Rift Basin (Håkansson \& Stemmerik 1989).

The Mesozoic basin evolution has been difficult to assess due to problems associated with correlating scattered outcrops and tectonic overprinting. However, recent studies have made such correlations possible. Hovikoski et al. (2018) provided a Jurassic-Cretaceous 


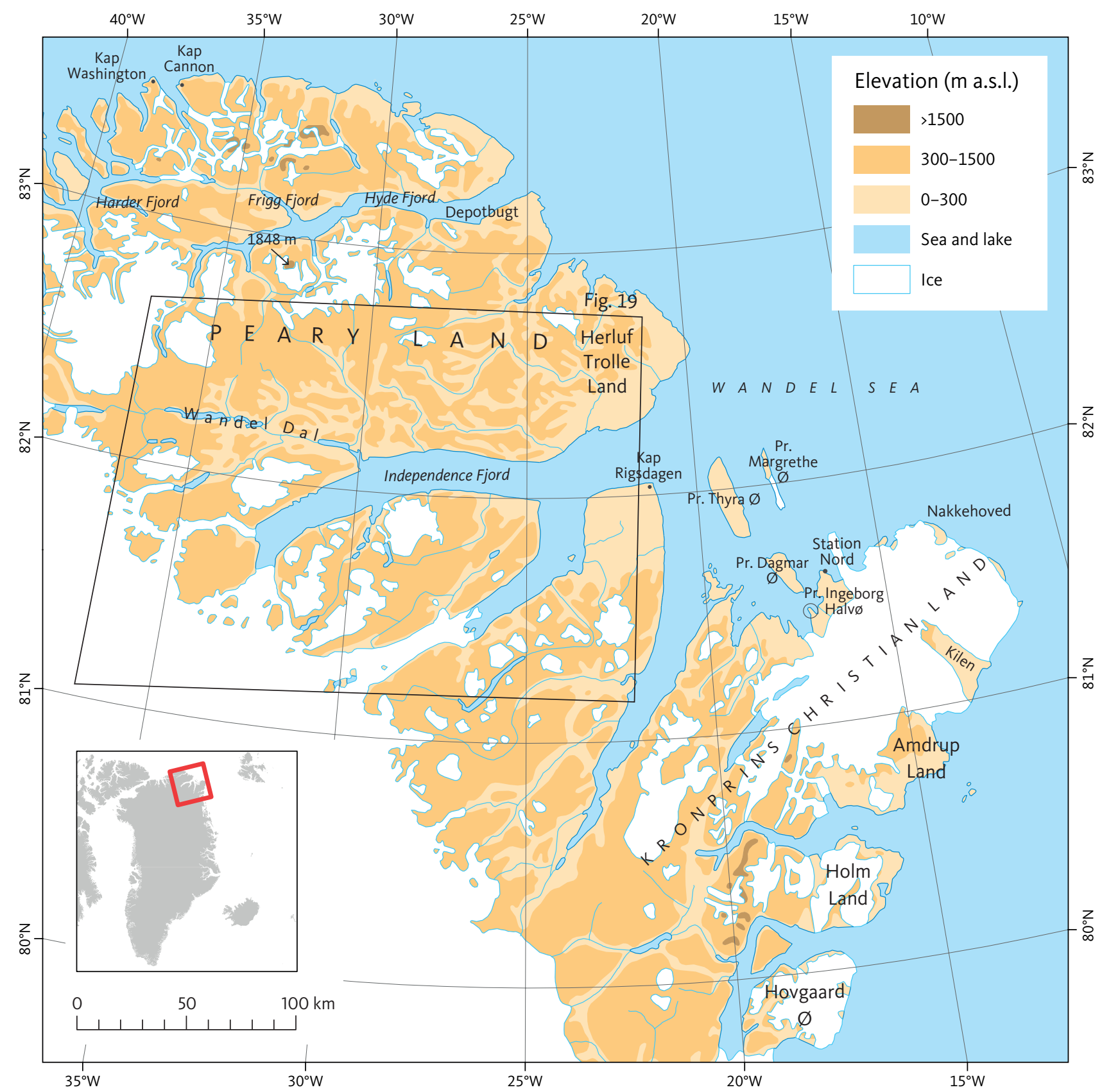

Fig. 3 Elevation and place names of the study area in eastern North Greenland. Pr: Prinsesse.

lithostratigraphy for Kilen (Kronprins Christian Land), and Bjerager er al. (2019) presented a Triassic (InduanNorian) lithostratigraphy for the Wandel Sea Basin.

Håkansson \& Stemmerik (1989) suggested that the Upper Jurassic to Cretaceous sediments accumulated in increasingly smaller sub-basins formed by strike-slip tectonics and transtension in what they called the 'Wandel Hav Strike-Slip Mobile Belt'. According to Håkansson \& Pedersen (1982, 2001, 2015), the 'Wandel Hav StrikeSlip Mobile Belt' is a north-west to south-east- striking wrench-fault deformation zone that was instrumental in all basin-forming events from the late Permian onwards and includes the following three, major fault systems (Fig. 4):

1. The south-west to north-east-trending Kap Cannon Thrust Zone (KCTZ) is exposed over c. $75 \mathrm{~km}$ in northernmost Peary Land. Ductile thrusting along the KCTZ took place between 49 and $47 \mathrm{Ma}$, estimated from the Ar-Ar dating of volcanic rocks of the Campanian to the earliest Paleocene Kap Washington Group (Tegner et al. 2011; Håkansson \& Pedersen 2015).

2. The east-west-trending Harder Fjord Fault Zone (HFFZ) is more than $300 \mathrm{~km}$ long and traverses Peary 


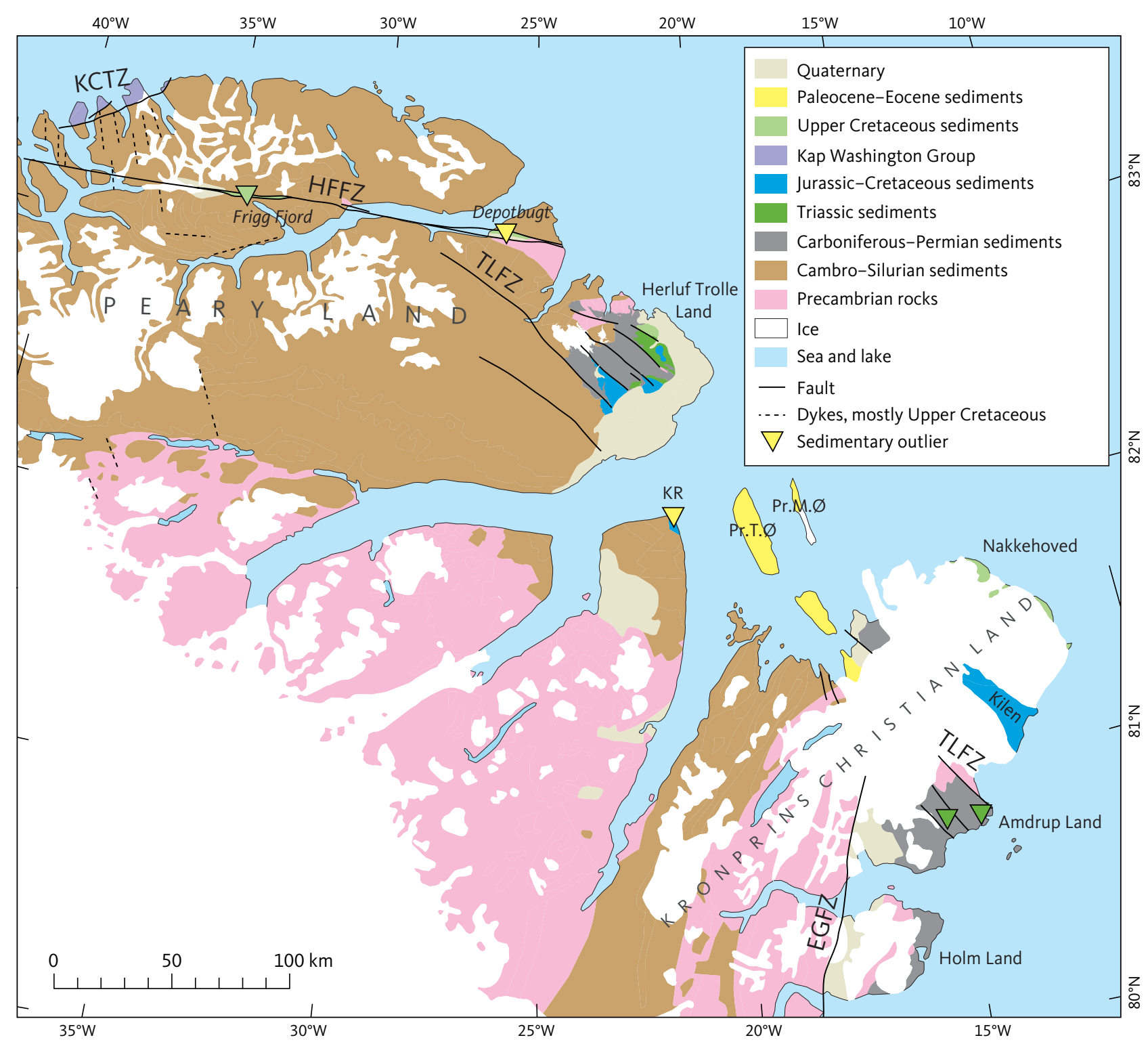

Fig. 4 Geology of the Carboniferous-Palaeogene Wandel Sea Basin and surrounding areas. The remnants of the Carboniferous to Palaeogene sediments occur between northern Peary Land and Kronprins Christian Land and thus define the extent of the basin. Kap Washington Group is of Campanian to earliest Palaeogene age (Håkansson \& Pedersen 2015). Håkansson \& Pedersen (2015) indicated the Trolle Land Fault Zone as one continuous zone from Herluf Trolle Land to Kronprins Christian Land. Here, we indicate one possible correlation between these two areas. Based on Escher \& Pulvertaft 1995 with modifications after Croxton et al. 1980; Hovikoski et al. 2018; Piasecki et al. 2018. EGFZ: East Greenland Fracture Zone. HFFZ: Harder Fjord Fault Zone. KCTZ: Kap Canon Thrust Zone. KR: Kap Rigsdagen. Pr.M.Ø: Prinsesse Margrethe Ø. Pr.T.Ø: Prinsesse Thyra Ø. TLFZ: Trolle Land Fault Zone.

Land within the metasediments of the Palaeozoic Franklinian Basin. Sediments as young as Late Cretaceous (and possibly Palaeogene) occur within the fault zone.

3. The north-west to south-east-trending Trolle Land Fault Z one (TLFZ) is more than $300 \mathrm{~km}$ long and 100 $\mathrm{km}$ wide and consists of a number of linear faults that cut through sediments as young as Late Cretaceous.

According to Piepjohn \& von Gosen (2003), the 'Wandel Hav Mobile Belt' (their term) is bordered by the HFFZ in the north and the TLFZ in the south-west. Paech \&
Estrada (2018) pointed out that the age relations between these fault zones and the Eurekan deformation stages are still unclear.

\subsection{Stratigraphic record}

Throughout this section, we refer the reader to the geological map and stratigraphic column for the Wandel Sea Basin presented in Figs. 4 and 5, respectively.

\subsubsection{Palaeozoic strata}

The fluvial deposits of the lower Carboniferous Sortebakker Formation (thickness $>1 \mathrm{~km}$ ) represent the 


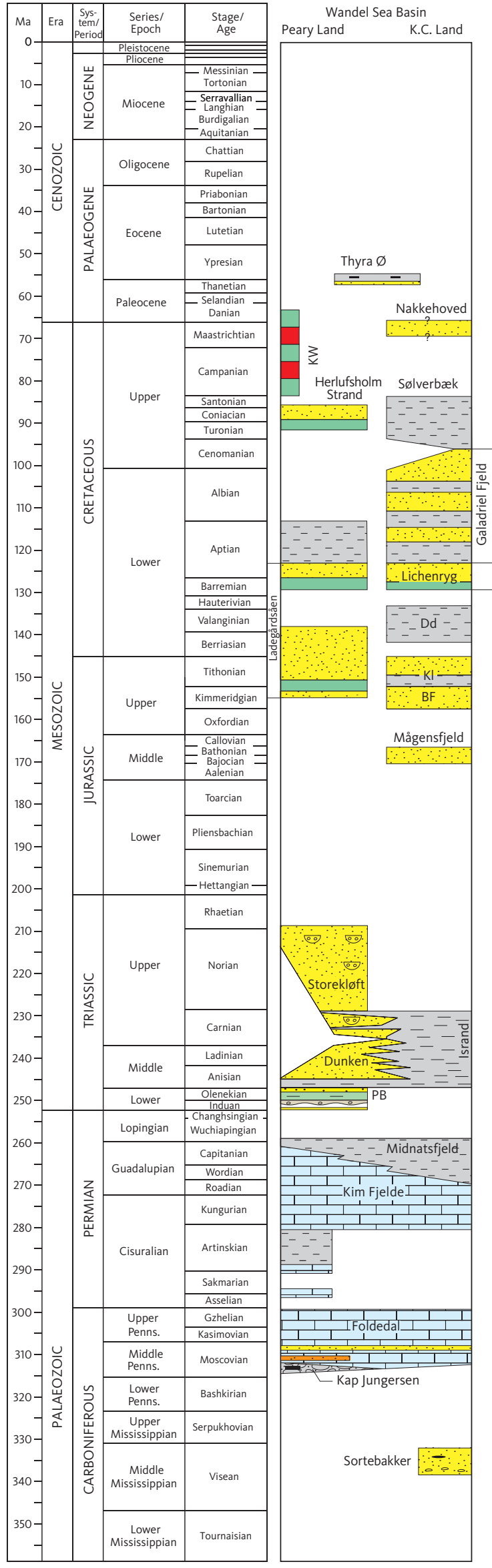

Legend

Sedimentary environments

Fluvial, lacustrine

Marine sandstone

Marine carbonate

Marine mudstone

Evaporites

Extrusive igneous rocks

Volcanics, volcanoclastics

Lithological symbols

ReOd Conglomerate

$\because \therefore$ Sandstone

$\overline{\dot{\Sigma} \div \overline{-}}$ Siltstone

$\square_{-}^{-}$Mudstone/shale

$\rightarrow \begin{aligned} & \text { Organic rich } \\ & \text { mudstone/shale }\end{aligned}$

Limestone

Coal layers

Channel fills
Fig. 5 Wandel Sea Basin stratigraphy and formation names. The representation of the mixed volcanic, volcano-clastic and lacustrine deposits of the Kap Washington Group has been simplified. Some formation names are not shown; the upper Permian Kap Kraka Fm in Peary Land (Håkansson \& Pedersen 2015) and the pre-late Bajocian (?) Gletscherport Fm in the Kilen area (Hovikoski et al. 2018). Compiled after Bjerager et al. 2019; Gautier et al. 2011; Håkansson \& Pedersen 2015; Hopper et al. 2014; Hovikoski et al. 2018; Ineson et al. 2020; Piasecki et al. 2018; Stemmerik et al. 1998; Svennevig et al. 2018; Tegner et al. 2011. BF: Birkelund Fjeld. Dd: Dromledome. K.C. Land: Kronprins Christian Land. KI: Kuglelejet. KW: Kap Washington Group. PB: Parish Bjerg. Penns: Pennsylvanian.

oldest unit of the Wandel Sea Basin. It crops out on Holm Land, where it rests directly on the crystalline basement affected by the Caledonian Orogeny (Stemmerik et al. 1998). The upper Carboniferous Kap Jungersen and Foldedal Formations show a marked variation from laterally widespread mixed siliciclastic-limestone cycles to dolomitised limestone where they crop out on the eastern Kronprins Christian Land. The Foldedal Formation is also exposed on Peary Land. Above a lower Permian hiatus, the middle to upper Permian limestones and shales of the Kim Fjelde and the Midnatfjeld Formations are exposed on Herluf Trolle Land and on eastern Kronprins Christian Land.

The upper Permian, fluvial to lacustrine deposits with syndepositional volcanics of the Kap Kraka Formation (>1.5 km; not shown) are located in the central part of Hyde Fjord, northern Peary Land, where the deposits are strongly compressed and bounded by the faults of the HFFZ (Håkansson \& Pedersen 2015). Unnamed Permian carbonates and deep-marine shales (>2 km) are exposed on Prinsesse Ingeborg Halvø, where they appear as thrust sheets bounded by two of the main faults of the TLFZ (Håkansson \& Pedersen 2015).

\subsubsection{Mesozoic strata}

The Wandel Sea Basin contains a nearly complete Triassic succession, with an estimated combined thickness 
of $700 \mathrm{~m}$ (Bjerager et al. 2019). The basal part of the Lower Triassic succession is fluvial, and the remaining Triassic succession is marine, representing a sand-dominated basin marginal succession in Peary Land to the west and a marine basinal mudstone succession in Kronprins Christian Land to the east. The succession includes the Lower Triassic Parish Bjerg Formation that crops out in northern Herluf Trolle Land where it rests unconformably on upper Permian sediments. The Triassic sediments on Herluf Trolle Land are bounded by two of the main faults of the TLFZ (Håkansson \& Pedersen 2015). Alsen et al. (2017) identified mainly the Middle Triassic Isrand Formation in the Kilen area on Kronprins Christian Land. This formation consists of laminated mudstones that accumulated in a slope and basin-floor setting in the eastern and deeper part of the Wandel Sea Basin. These deposits accumulated at the same time as shallow-marine mudstones of the Dunken Formation on Herluf Trolle Land (Alsen et al. 2017). A sedimentary outlier in Amdrup Land is now dated as Early Triassic (Alsen et al. 2017).

A minor outcrop of Middle Jurassic (Bajocian) muddy sandstones occurs within a few square kilometres on central Herluf Trolle Land within a dense fault complex in the centre of a broad domal structure (Håkansson \& Pedersen 2015).

Upper Jurassic - Lower Cretaceous mainly marine sandstones and sandy shales of the Ladegårdsåen Formation (250 m) crop out on Herluf Trolle Land. The upper Ladegårdsåen Formation is a sandstone-dominated unit deposited in a fluvial through estuarine to fully marine environment, and it rests unconformably on the marine sandstones of the lower Ladegårdsåen Formation (Ineson et al. 2020). The lower part of the formation rests unconformably on Palaeozoic rocks within several isolated, typically fault-bounded occurrences across most of the TLFZ (Håkansson \& Pedersen 2015). Piasecki et al. (2018) identified a c. $75 \mathrm{~m}$ high sedimentary section exposed at Kap Rigsdagen as part of Ladegårdsåen Formation, overlain by 5-10 m of the Palaeogene Thyra $\varnothing$ Formation (see Section 2.1.3).

Unnamed Lower Cretaceous (Albian-Aptian), mainly marine mudstones (c. $100 \mathrm{~m}$ ) bounded by faults, crop out within a few square kilometres on central Herluf Trolle Land (Håkansson \& Pedersen 2015).

Turonian to Coniacian, fluvial to marginally marine sand-shale series of the Herlufsholm Strand Formation (500 m) crops out on northern Herluf Trolle Land. The sediments are bounded by the northernmost fault of the TLFZ, and they rest unconformably on Palaeozoic sediments (Håkansson \& Pedersen 2015).

The poorly dated Upper Cretaceous marine sandstone of the Nakkehoved Formation (>600 m) crops out on the north coast of Kronprins Christian Land, near the northern margin of the TLFZ (Håkansson \& Pedersen 2015). The sandstone is gently folded, but intensely cut by a swarm of mono-mineralic quartz veins in the modestly deformed sandstone. The vein system is essentially confined to a small semi-nunatak in the ice cap (Håkansson et al. 1994).

Hovikoski et al. (2018) argued that Kilen contains the thickest and stratigraphically most complete Jurassic and Cretaceous sediment succession in North Greenland and presented a new stratigraphic scheme. The Jurassic succession (>500 $\mathrm{m}$ ) is divided into four formations consisting of lagoon and shallow-marine sediments: the poorly dated Gletscherport Formation, the Mågensfjeld and Birkelund Fjeld Formations of Bajocian-Bathonian and Kimmeridgian age, respectively, and the Volgian Kuglelejet Formation. The Lower Cretaceous interval (>1500 $\mathrm{m}$ ) is divided into three formations consisting of deep shelf to fluvial and shoreface sediments: the late Ryazanian to Hauterivian Dromledome Formation, the unfossiliferous Lichenryg Formation and the late Aptian to middle Cenomanian Galadriel Fjeld Formation.

The Lichenryg Formation and the contemporaneous upper Ladegårdsåen Formation in Peary Land show close stratigraphic and palaeo-environmental parallels: both overlie an Hauterivian - early Barremian, erosional unconformity and show clear transgressive trends from fluvial through estuarine to fully marine (Ineson et al. 2020). Ineson et al. (2020) interpreted the succession to record Hauterivian - early Barremian regional uplift and erosion followed by fluvial sedimentation and subsequent transgression in the late Barremian - early Aptian. It was suggested that the uplift heralded the onset of the High Arctic Large Igneous Province (HALIP) at about $135 \mathrm{Ma}$ and marked the initiation of the Amerasia Basin (Døssing et al. 2013).

The Upper Cretaceous marine succession (650 m) is assigned to the late Cenomanian to Santonian Sølverbæk Formation dominated by mudstones and sandstone-mudstones. Intense compressive deformation affected the Mesozoic deposits in Kilen (Håkansson \& Pedersen 2001, 2015; Svennevig et al. 2016, 2017).

Unnamed, deep-marine, siliciclastic sediments ( $>400 \mathrm{~m}$ ) of Santonian age occur in the Frigg Fjord area, bounded by the HFFZ, and their near-vertical orientation indicates substantial shortening (Håkansson \& Pedersen 2015). The sediments are intruded by doleritic dikes and sills of similar composition to the basalts of the Kap Washington Group, and these intrusions are affected by deformation along the HFFZ (Paech \& Estrada 2018). Further east along the HFFZ, about $500 \mathrm{~m}$ of Upper Cretaceous, mainly fluvial sandstone occur in 
the Depotbugt area (Håkansson \& Pedersen 2015). Their similarity to the Herlufsholm Strand Formation has been used to date these sediments.

Volcanics and volcanoclastics interbedded with fluvial and lacustrine deposits of the Campanian to lowermost Palaeogene Kap Washington Group ( $>5 \mathrm{~km}$ ) occur on the north coast of Peary Land (Håkansson \& Pedersen 2015). Most of the volcanics were emplaced at 71-68 Ma but activity continued into the Paleocene (Tegner et al. 2011). The deposits, which overlie Palaeozoic strata, are bounded on all sides by the thrusts of the KCTZ, interpreted as reactivated normal faults (Håkansson \& Pedersen 2015).

\subsubsection{Palaeogene strata}

The fine-grained sandstones, siltstones and coal of the Thyra $\varnothing$ Formation that crop out on Prinsesse Thyra $\varnothing$, Prinsesse Dagmar $\varnothing$, Prinsesse Margrethe $\varnothing$ and Prinsesse Ingeborg Halvø are dated as late Paleocene to possibly earliest Eocene age, with an estimated composite thickness of $50 \mathrm{~m}$ (Lyck \& Stemmerik 2000). Håkansson et al. (1991) interpreted the depositional environment as dominantly fluviatile; however, Lyck \& Stemmerik (2000) documented a marine influenced environment. In contrast to the folded and thrusted Upper Cretaceous and older deposits within the HFFZ and TLFZ (e.g. in Kilen), the deposits of the Thyra $\varnothing$ Formation are often reported as undeformed (Håkansson \& Pedersen 1982, 2015; Boyd et al. 1994; Lyck \& Stemmerik 2000), but some deformational structures are also reported (Pedersen \& Håkansson 2001; Piepjohn \& von Gosen 2001; Guarnieri 2015). The base of the formation is not known (Lyck \& Stemmerik 2000) and on Prinsesse Ingeborg Halvø, the Palaeogene deposits are in contact with late Paleozoic sediments along a wide fault zone (see Section 2.2).

Minor outliers of Palaeogene carbonaceous, terrestrial shales occur in the Depotbugt area near the Upper Cretaceous outcrops (Håkansson \& Pedersen 2015; Paech \& Estrada 2018). Croxton et al. (1980) dated a sparse pollen flora from these deposits as Eocene in age, and Paech \& Estrada (2018) noted that they were flat lying. Piasecki et al. (2018) identified the upper 5-10 $\mathrm{m}$ of the sedimentary section exposed at Kap Rigsdagen to be of early to middle Eocene age and to be part of the Thyra $\varnothing$ Formation, above sediments of Ladegårdsåen Formation separated by a 65 Myr hiatus. Abundant, reworked Cretaceous dinoflagellate cysts are common in the Thyra $\varnothing$ Formation (Lyck \& Stemmerik 2000; Piasecki et al. 2018). Extensive reworking shows that Cretaceous units were exposed and actively eroded during deposition of the Thyra $\varnothing$ Formation (Piasecki et al. 2018).

\subsection{Structural elements of the Wandel Sea \\ Basin and their relation to the Eurekan \\ Orogeny}

In this section, we discuss the dominant structural elements of the Wandel Sea Basin and their relation to the Eurekan Orogeny. We use the term Eurekan Orogeny to mean deformation caused by the Palaeogene convergence between Greenland, the Canadian Arctic and Svalbard (Figs. 1, 2). We use the development of the seafloor spreading in the North-East Atlantic to define the following two stages of the Eurekan Orogeny:

1. Sea-floor spreading in the Labrador Sea and Baffin Bay started in the mid-Paleocene (magnetochron C27; c. $62 \mathrm{Ma}$ ). The movement of Greenland relative to the Canadian Arctic and Svalbard resulted in the first stage of the Eurekan Orogeny (phase 1 of Gion et al. [2017] and phase 2 of Oakey \& Chalmers [2012]).

2. Greenland and Eurasia moved together until the latest Paleocene (before C24, c. 55 Ma; Gaina et al. 2017), when the sea-floor spreading started between Greenland and Europe. Subsequently, Greenland moved north relative to the Arctic Islands, which resulted in the second stage of the Eurekan Orogeny (phase 2 of Gion et al. [2017] and phase 3 of Oakey \& Chalmers [2012]).

Sea-floor spreading between Greenland and North America ceased at the end of the Eocene (C13, c. $35 \mathrm{Ma})$, when Greenland became attached to North America and the Eurekan Orogeny ended.

Phases 1 and 4 of Oakey \& Chalmers (2012) consist only of continental extensional movements between Greenland and North America prior to the mid-Paleocene and of continued movement of the new Greenland - North America plate relative to Eurasia after the Eocene. None of the movements during these phases are, here, attributed to the Eurekan Orogeny.

Initial movement during the Paleocene led to the formation of foreland basins, for example, the Central Tertiary Basin (CTB) on Svalbard, and to initial transpression on Ellesmere Island, where there was also some compression on at least one step-over between strike-slip faults during the first Eurekan stage, defined above. A subsequent change of direction of Greenland relative to North America during the Eocene resulted in compression on Ellesmere Island and transpression on Svalbard during the second Eurekan stage (Steel et al. 1985; Ricketts 1994; Harrison et al. 1999; Faleide et al. 2008; Oakey \& Chalmers 2012; Dallmann 2015; Embry \& Beauchamp 2019). The Svalbard margin evolved through strike-slip movements along the plate boundary, the De Geer Line, where Greenland slid past Svalbard (Steel et al. 1985; 
Faleide et al. 2008). The Eurekan Orogeny came to an end when the movement ceased between Greenland and North America at the end of the Eocene (Oakey \& Chalmers 2012; Piepjohn et al. 2016). Sea-floor spreading between Greenland and Svalbard began in the early Miocene (Jokat et al. 2016).

Håkansson \& Pedersen (2015) observed a $45^{\circ}$ offset in the plate boundary between North Greenland and Svalbard relative to the main trend of rifting and spreading in the North-East Atlantic. As a result, this segment of the plate boundary experienced episodes of combined transtension and transpression, in part controlled by the movement of a temporarily independent Greenland Plate. They concluded that the upper Permian - Mesozoic deposits of the Wandel Sea Basin record the plate-boundary history along this offset in a series of disturbed, pull-apart basins. They assigned most of these basins to four tectonic episodes that were finally overprinted by the compressional Kronprins Christian Land Orogeny (Fig. 2). According to these authors, the timing of this orogeny is bracketed by the age of the deformed strata (Upper Cretaceous) and the age of the undeformed cover successions (Thyra $\varnothing$ Formation), and thus, occurred during a comparatively brief period around the Cretaceous-Palaeogene boundary.

The initial formation of the long, linear faults of the TLFZ was related to deformational events in late Palaeozoic, Triassic-Jurassic and Late Cretaceous times (von Gosen \& Piepjohn 2003). Piepjohn \& von Gosen (2001) observed dextral transpressive deformation, coeval with north-south compression at the HFFZ and KCTZ, which they interpreted as Eurekan. von Gosen \& Piepjohn (2003) argued that the Eurekan transpressive deformation of the Wandel Sea Basin was younger than the Thyra Ø Formation and thus of post-Paleocene age, probably Eocene. They interpreted a dextral displacement of the Thyra $\varnothing$ Formation relative to upper Palaeozoic strata within a wide fault zone on Prinsesse Ingeborg Halvø to have occurred in the early Eocene during the deformation of the HFFZ and KCTZ. In contrast, Pedersen \& Håkansson (2001) explained the displacement of the Thyra $\varnothing$ Formation along the fault in terms of post-Paleocene down-faulting after cessation of compression. Håkansson \& Pedersen (2001, 2015), therefore, suggested that the compressive tectonics had come to an end before the deposition of the Thyra $\varnothing$ Formation. Guarnieri (2015) identified compressive structures and reverse fault planes along the contact on Prinsesse Ingeborg Halvø and interpreted them as a Paleocene thrust fault, offset by strike-slip faults of probable Eocene. To our knowledge, Prinsesse Ingeborg Halvø is the only locality where the sediments of the Thyra $\varnothing$ Formation are observed in contact with older rocks, and thus, the timing of the end of compressional tectonics remains to be speculative.
Svennevig et al. $(2016,2017)$ interpreted the Cretaceous succession exposed on Kilen as a rift basin, dominated by post-Coniacian extensional faults and overprinted during north-south compression that possibly occurred during the Paleocene-Eocene. Svennevig et al. (2016) also presented a new structural model for the development of the TLFZ based on observations from Kilen. Previous structural models interpreted rhombic-shaped fault patterns as evidence for strike-slip tectonics. However, these authors demonstrated the structures to be the result of post-Coniacian, north-east to south-west extension defined by north-west to south-east-trending normal faults, followed later by north-south compression that folded the faults passively. Consequently, the strike-slip faults had only minor status in the resulting basin inversion. Svennevig et al. (2016) considered the age of the compressional event on Kilen to be post-Coniacian, since the youngest Cretaceous outcrops are Coniacian in age. Hovikoski et al. (2018) dated these outcrops as Santonian. They also thought that a late Paleocene - early Eocene age for the north-south compression on Kilen was found to be compelling because (1) the Ar-Ar systematics of volcanics of the Kap Washington Group (200 km northwest of Kilen) were partially reset in the early Eocene (Tegner et al. 2011), (2) the West Spitsbergen Fold Belt on the conjugate Barents margin has been dated to be late Paleocene-Eocene in age (Maher et al. 1995) and (3) plate reconstructions showed transpression with $18^{\circ}$ convergence in the late Paleocene ( $60 \mathrm{Ma}$ ) that culminated in the early Eocene (54-50 Ma; Svennevig et al. (2016) based on Müller et al. 2016).

\section{Apatite Fission-Track Analysis}

A variety of scenarios have been proposed in the literature to explain the complex tectonic development of the Wandel Sea Basin. Studies in the region describe multiple episodes of folding and faulting, although the timing remains uncertain. Here, we present AFTA data and thermal history interpretations, with the aim of placing firmer constraints on the timing of key tectonic events.

AFTA is a method for determining thermal histories of rocks at temperatures generally less than $130^{\circ} \mathrm{C}$. Thermal history constraints derived from AFTA can be converted into information on former depths of burial and amounts of exhumation. In the method, radiation damage features known as 'fission tracks' are analysed. Fission tracks form in accessory apatite crystals separated from igneous rocks or in detrital apatite grains obtained from sandstones and other clastic rock types. The number of tracks per unit area of a polished grain surface depends on the uranium content, the time over which tracks have accumulated and the distribution of track lengths in the sample. If all tracks have the same length, then by measuring the 
track density and the uranium content, a 'fission-track age' can be measured. In the absence of other factors, this age represents the time over which tracks accumulated. Once formed, the damage is progressively repaired, and the tracks shorten at a rate dependent on temperature. The probability of intersecting a polished surface depends on the track length, and shortened tracks produce a lower contribution to the track density than longer tracks, resulting in a reduced fission-track age. As a result, a measured fission-track age does not denote the timing of a specific event and must be assessed together with the distribution of track lengths, referred to as 'confined tracks'. These tracks are totally enclosed within the grains and have been etched because they intersect tracks etched from the surface. The principles of the AFTA method are further described in Japsen et al. (in press), Green \& Duddy (2012) and Green et al. (2013).

\subsection{New AFTA data from northern and eastern Greenland}

This research study presents new AFTA data from 52 outcrop samples of basement and sedimentary rocks in northern and eastern Greenland (Fig. 6; Tables 1, 2 and the Supplementary File S1). Of these, 46 are from eastern North Greenland (north of $79^{\circ} \mathrm{N}$; east of $40^{\circ} \mathrm{W}$ ) and 6 are from North-East Greenland (between 74 and $79^{\circ} \mathrm{N}$ ). Sixteen further samples were processed but did not yield apatite. As far as we are aware, no apatite fission-track data have yet been reported from Greenland north of $80.5^{\circ} \mathrm{N}$.

Methods for sample preparation and analysis, basic AFTA data and thermal history interpretations derived from AFTA data for all samples were first reported in Geotrack report GC1113 (Green 2014) - a report prepared by Geotrack International, Australia, for the Geological Survey of Denmark and Greenland, as provided in Supplementary File S2. In brief, rock samples are crushed to sand grade and heavy minerals are separated using standard density and magnetic techniques. Apatite grains are mounted in epoxy on glass slides, polished and etched in dilute nitric acid. The etched grain mounts are then fixed to mica sheets and irradiated with thermal neutrons. After irradiation, the mica sheets are detached from the grain mount and etched in hydrofluoric acid. Finally, the etched grain mounts and mica sheets are mounted next to each other on a microscope slide for track counting and length measurement.
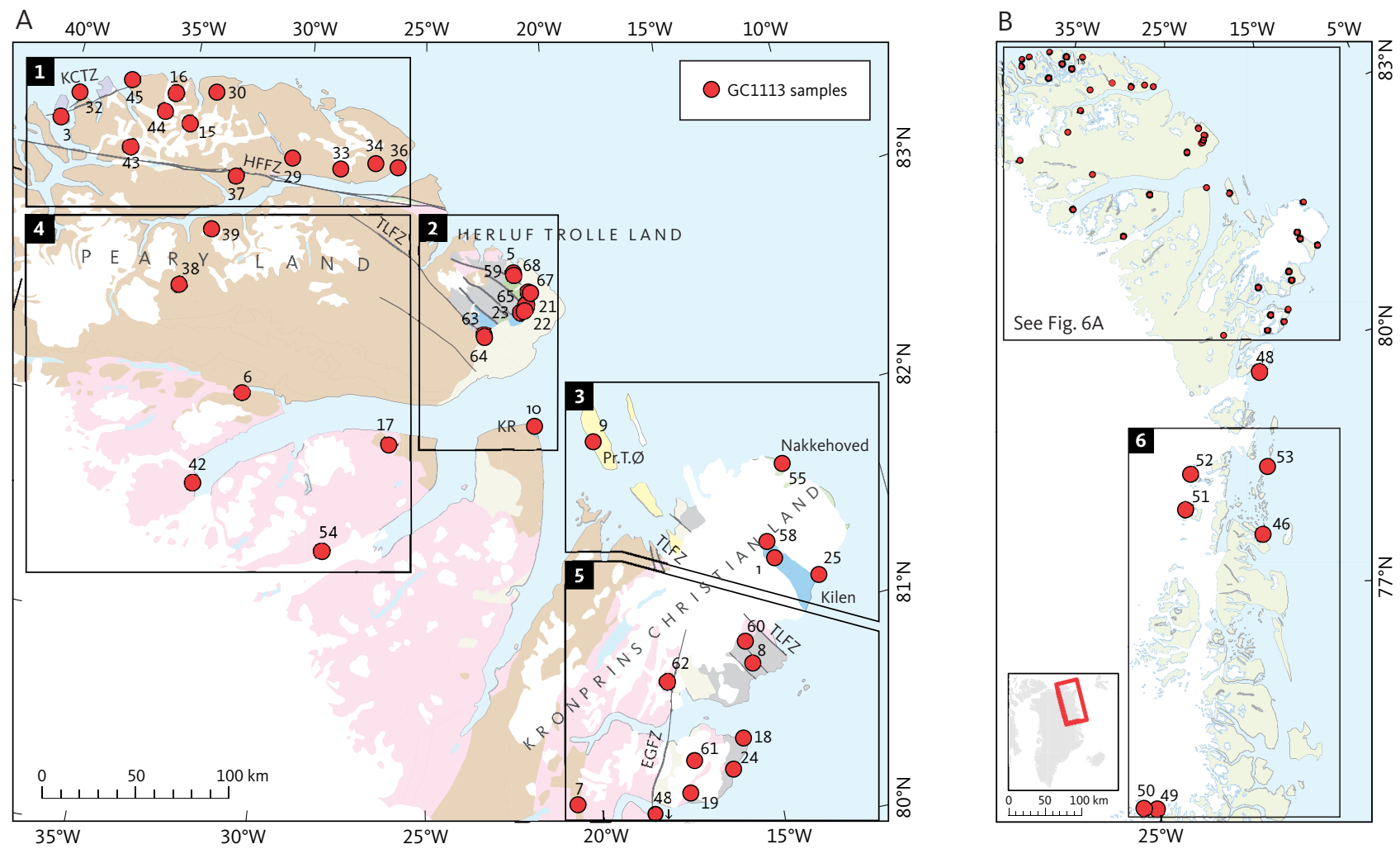

Fig. 6 Location of samples that yielded apatite and division of the study area into six geographical areas with similar thermal histories used to define the timing of key episodes in Fig. 10. A: Areas 1-5. B: Area 6. Geology legend in Fig. 4. EGFZ: East Greenland Fracture Zone. HFFZ: Harder Fjord Fault Zone. KCTZ: Kap Canon Thrust Zone. KR: Kap Rigsdagen. Pr.T.Ø: Prinsesse Thyra Ø. TLFZ: Trolle Land Fault Zone. 
Table 1 Sample details. A digital version of this table is available in online Supplementary File S1

\begin{tabular}{|c|c|c|c|c|c|c|c|}
\hline $\begin{array}{l}\text { Sample } \\
\text { number } \\
\text { GC1113- }\end{array}$ & Stratigraphic age & $\begin{array}{c}\text { Chronstratigraphic } \\
\text { age (Ma) }\end{array}$ & Rock type & Latitude & Longitude & $\begin{array}{l}\text { Elevation } \\
\text { (m a.s.l.) }\end{array}$ & Location \\
\hline$\overline{1}$ & Coniacian & $89-85$ & Conglomerate & -14.0866 & 81.3477 & 250 & KCL, Kilen \\
\hline 3 & Cambrian & $542-488$ & Quartzite & -40.1618 & 83.2950 & 465 & Lockwood $\varnothing$ \\
\hline 5 & Cretaceous, L & $100-65$ & Sandstone & -21.6885 & 82.7712 & 110 & HTL, Foldedal \\
\hline 6 & Cambrian, E & $542-513$ & Sandstone & -31.4713 & 82.1574 & 114 & $\begin{array}{l}\text { Heilprin Land, } \\
\text { Glaciologelv }\end{array}$ \\
\hline 7 & Cambrian, E & $542-513$ & Sandstone & -20.6893 & 80.2133 & 160 & Pr. CM Alper \\
\hline 8 & Carboniferous, E & $360-318$ & Sandstone & -15.1754 & 80.7875 & 100 & $\mathrm{AL}$, Sommerterrassen \\
\hline 9 & Palaeogene, E & $66-61$ & sand/coal & -19.2820 & 81.9368 & 12 & Pr. Thyra Ø \\
\hline 10 & Jurassic, L - Cretaceous, E & $161-100$ & Sandstone & -21.2511 & 82.0323 & 23 & Kap Rigsdagen \\
\hline 15 & Cambrian & $542-488$ & Psammite & -34.8881 & 83.3972 & 1341 & JVJL, Polkorridoren \\
\hline 16 & Cambrian & $542-488$ & Marble? & -35.6985 & 83.5279 & 320 & JVJL, Sands Fjord \\
\hline 17 & Neoproterozoic & $1600-1000$ & Sandstone & -26.2725 & 81.9563 & 275 & ICCL, Neergaard Dal \\
\hline 18 & Carboniferous, $\mathrm{L}$ & $318-299$ & Sandstone & -15.7926 & 80.4417 & 20 & HL, Eskimonæs \\
\hline 19 & Carboniferous, E & $360-318$ & Sandstone & -17.4994 & 80.2161 & 50 & HL, Sortebakker \\
\hline 21 & Oxfordian-Barremian & $161-130$ & Sandstone & -21.4981 & 82.5801 & 157 & HTL, Kim Fjelde \\
\hline 22 & Triassic, E & $251-247$ & Sandstone & -21.3657 & 82.5852 & 200 & HTL, Kim Fjelde \\
\hline 23 & Triassic, E & $251-247$ & Sandstone & -21.2864 & 82.6155 & 190 & HTL, Falkefjeld \\
\hline 24 & Carboniferous, L & $318-299$ & Sandstone & -16.2082 & 80.3018 & 37 & $\mathrm{HL}$, Hanseeraq Fjord \\
\hline 25 & Albian & $112-100$ & Sandstone & -12.6921 & 81.1447 & 25 & KPC, Kilen \\
\hline 29 & Cambrian, Ellesm. deform. & $542-488$ & Psammite & -30.5000 & 83.3000 & 400 & $J V J L$ \\
\hline 30 & Cambrian, Ellesm. deform. & $542-488$ & - & -34.0000 & 83.5667 & 340 & $J \mathrm{JJL}$ \\
\hline 32 & Cretaceous, L /Palaeogene & $80-50$ & Rhyolite & -39.6667 & 83.4333 & 410 & $J \mathrm{JJL}$ \\
\hline 33 & Cambrian, Ellesm. deform. & $542-488$ & Arkose & -28.5000 & 83.2667 & 825 & $J \mathrm{JJL}$ \\
\hline 34 & Cambrian, Ellesm. deform. & $542-488$ & Psammite & -27.0833 & 83.3000 & 460 & $J V J L$ \\
\hline 36 & Cambrian, Ellesm. deform. & $542-488$ & Sandstone & -26.1667 & 83.2833 & 20 & JVJL \\
\hline 37 & Cretaceous, L /Palaeogene & $80-50$ & Gabbro & -32.7000 & 83.1833 & 950 & $J V J L$ \\
\hline 38 & Silurian & $444-416$ & Greywacke & -34.2520 & 82.2700 & 775 & $\mathrm{PL}$ \\
\hline 39 & Silurian & $444-416$ & Sandstone, partly & -37.6167 & 83.9333 & 600 & $\mathrm{PL}$ \\
\hline 42 & Palaeoproterozoic & $2500-1600$ & Sandstone & -32.7500 & 81.7009 & 720 & $\mathrm{PL}$, Vildtland \\
\hline 43 & Cambrian, Ellesm. deform. & $542-488$ & Conglomerate & -37.1000 & 83.2333 & 390 & $J \mathrm{JJL}$ \\
\hline 44 & Cambrian, Ellesm. deform. & $542-488$ & Psammite & -36.0000 & 83.4333 & 1180 & $J V J L$ \\
\hline 45 & Cambrian, Ellesm. deform. & $542-488$ & Schist & -37.6333 & 83.5500 & 80 & $\mathrm{JVJL}$ \\
\hline 46 & Precambrian, Caled. deform. & $2500-1600$ & Metagabbro & -19.5000 & 77.8000 & 30 & $\begin{array}{l}\text { Gamma } \varnothing, \\
\text { Nordmarken }\end{array}$ \\
\hline 48 & Precambrian, Caled. deform. & $2500-1600$ & Gabbro & -18.4012 & 79.7217 & 250 & Hovgaard $\varnothing$ \\
\hline 49 & Precambrian, Caled. deform. & $2500-1600$ & Mica schist & -25.1697 & 74.4372 & 1450 & $\mathrm{BL}$ \\
\hline 50 & Precambrian, Caled. deform. & $2500-1600$ & Mica schist & -25.7823 & 74.4418 & 1305 & $\mathrm{BL}$ \\
\hline 51 & Precambrian, Caled. deform. & $2500-1600$ & Gneiss & -23.6667 & 78.1000 & 900 & $\begin{array}{l}\text { KFVIIIL, Bildsøe } \\
\text { Nunatakker }\end{array}$ \\
\hline 52 & Precambrian, Caled. deform. & $2500-1600$ & Banded sequence & -23.3167 & 78.5333 & 660 & $\begin{array}{l}\text { KFVIIIL, Grønne } \\
\text { Nuuatak }\end{array}$ \\
\hline 53 & Precambrian, Caled. deform. & $2500-1600$ & Gneiss & -18.5500 & 78.5667 & 10 & $\begin{array}{l}\text { Franske Øer, Kap } \\
\text { Bergendahl }\end{array}$ \\
\hline 54 & Palaeoproterozoic & $2500-1600$ & Siltstone & -28.3333 & 81.4333 & 251 & $\mathrm{ICCL}$ \\
\hline 55 & Cretaceous, L & $100-65$ & Sandstone & -13.1110 & 81.6990 & 276 & KCL,Nakkehoved \\
\hline 58 & Cretaceous, E & $145-100$ & Sandstone & -13.9481 & 81.2638 & 264 & $\mathrm{KCL}$, Dromledome \\
\hline 59 & Cretaceous, L & $100-65$ & Sandstone & -21.6794 & 82.7600 & 130 & HTL \\
\hline 60 & Mesoproterozoic & $1600-1000$ & Metasediments & -15.2836 & 80.8965 & 320 & $\mathrm{AL}$ \\
\hline 61 & Archaean & $>2500$ & Gneiss & -17.1175 & 80.4068 & 952 & $\mathrm{HL}$ \\
\hline 62 & Mesoproterozoic & $1600-1000$ & Sandstone & -17.7671 & 80.7579 & 997 & AL, Tobias Gletscher \\
\hline 63 & Silurian & $444-416$ & Sandstone & -22.8773 & 82.4813 & 122 & HTL, Vitskøl Elv \\
\hline 64 & Oxfordian-Barremian & $161-130$ & Sandstone & -22.8718 & 82.4682 & 277 & HTL, Vitskøl Elv \\
\hline 65 & Triassic, M & $245-237$ & Sandstone & -21.2546 & 82.6158 & 250 & HTL, Hjulsporsdalen \\
\hline 67 & Triassic, M & $245-237$ & Sandstone & -21.0833 & 82.6703 & 229 & HTL, Dunken \\
\hline 68 & Oxfordian-Barremian & $161-130$ & Sandstone & -21.1756 & 82.6753 & 642 & HTL, Dunken \\
\hline
\end{tabular}

AL: Amdrup Land; BL: Bartholin Land; HL: Holm Land; HTL: Herluf Trolle Land; ICCL: IC Christensen Land; JVJL: JV Jensen Land; KCL: Kronprins Christian Land; KFVIIIL: Kong Frederik VIII Land; PL: Peary Land; Pr CM Alper: Prinsesse Caroline Matilde Alper; Pr Thyra Ø: Prinsesse Thyra Ø; E: Early; M: Middle; L: Late; Caled.: Caledonian; Ellesm.: Ellesmerian. 
Table 2 AFTA data. A digital version of this table is available in online Supplementary File S1

\begin{tabular}{|c|c|c|c|c|c|c|c|c|}
\hline $\begin{array}{l}\text { Sample } \\
\text { number } \\
\text { GC1113- }\end{array}$ & $\begin{array}{l}\text { Stratigraphic } \\
\text { age }(\mathrm{Ma})^{\text {a }}\end{array}$ & $\begin{array}{c}\rho D^{b}\left(10^{6} \text { tracks } /\right. \\
\left.\mathrm{cm}^{2}\right)\end{array}$ & $\begin{array}{c}\rho \mathrm{s}^{\mathrm{b}}\left(10^{6} \text { tracks } /\right. \\
\left.\mathrm{cm}^{2}\right)\end{array}$ & $\begin{array}{c}\rho \mathrm{i}^{\mathrm{b}}\left(10^{6} \text { tracks/ }\right. \\
\left.\mathrm{cm}^{2}\right)\end{array}$ & $\begin{array}{l}\left(\mathrm{P}^{2}\right)^{2}(\%)(\mathrm{no} \\
\text { of grains) }\end{array}$ & $\begin{array}{l}\text { Fission track } \\
\text { age }^{\mathrm{d}}(\mathrm{Ma})\end{array}$ & $\begin{array}{l}\text { Mean track } \\
\text { length } \mathrm{e}(\mu \mathrm{m})\end{array}$ & $\begin{array}{l}\text { Std. dev. }{ }^{f} \\
\quad(\mu \mathrm{m})\end{array}$ \\
\hline 1 & $89-85$ & 1.209 (1998) & $0.343(138)$ & $2.698(1085)$ & $38(20)$ & $29.2 \pm 2.8$ & $14.1 \pm 0.8(7)$ & 2.05 \\
\hline 3 & $542-488$ & 1.215 (1998) & $0.557(143)$ & 3.607 (926) & $<1(20)$ & $38.8 \pm 4.9 \dagger$ & $14.2 \pm 0.4(12)$ & 1.51 \\
\hline 5 & $100-65$ & $1.222(1998)$ & $0.044(25)$ & $0.258(148)$ & $37(20)$ & $39.1 \pm 8.5$ & $14.7 \pm 0.3(8)$ & 0.72 \\
\hline 6 & $542-513$ & $1.228(1998)$ & 1.807 (522) & $2.552(737)$ & $<1(16)$ & $165.9 \pm 17.5 \dagger$ & $12.7 \pm 0.3(27)$ & 1.58 \\
\hline 7 & $542-513$ & 1.235 (1998) & $1.120(642)$ & 1.950 (1118) & $3(20)$ & $127.1 \pm 9.6 \dagger$ & $12.8 \pm 0.2(55)$ & 1.64 \\
\hline 8 & $360-318$ & 1.241 (1998) & $1.578(568)$ & $1.842(663)$ & $47(20)$ & $199.1 \pm 12.6$ & $12.8 \pm 0.2(72)$ & 1.50 \\
\hline 9 & 66-61 & 1.248 (1998) & $0.969(344)$ & $1.375(488)$ & $9(20)$ & $165.6 \pm 16.5 t$ & $12.8 \pm 0.4(44)$ & 2.35 \\
\hline 10 & $161-100$ & 1.254 (1998) & $0.542(195)$ & $1.036(373)$ & $3(19)$ & $127.0 \pm 15.8 \dagger$ & $11.2 \pm 0.5(15)$ & 1.80 \\
\hline 15 & $542-488$ & 1.260 (1998) & $0.334(176)$ & 2.786 (1469) & $6(20)$ & $28.7 \pm 2.4$ & $14.0 \pm 0.4(24)$ & 1.88 \\
\hline 16 & $542-488$ & 1.267 (1998) & $0.037(27)$ & $0.134(97)$ & 99 (19) & $66.7 \pm 14.6$ & $14.2 \pm 0.5(2)$ & 0.64 \\
\hline 17 & $1600-1000$ & $1.273(1998)$ & $1.306(637)$ & $1.837(896)$ & $4(20)$ & $173.1 \pm 14.3 \dagger$ & $13.0 \pm 0.2(54)$ & 1.37 \\
\hline 18 & $318-299$ & $1.280(1998)$ & 1.499 (599) & 2.275 (909) & $4(18)$ & $153.8 \pm 11.8 \dagger$ & $11.3 \pm 0.3(21)$ & 1.28 \\
\hline 19 & $360-318$ & $1.292(1998)$ & $1.130(833)$ & 1.566 (1154) & $68(20)$ & $175.0 \pm 9.2$ & $12.3 \pm 0.2(100)$ & 1.71 \\
\hline 21 & $161-130$ & 1.292 (1998) & $0.712(288)$ & $2.088(845)$ & $<1(20)$ & $83.4 \pm 9.3 \dagger$ & $11.9 \pm 0.6(17)$ & 2.28 \\
\hline 22 & $251-247$ & 1.299 (1998) & $1.140(594)$ & 2.140 (1115) & $<1(20)$ & $127.0 \pm 11.9 \dagger$ & $12.1 \pm 0.2(89)$ & 2.06 \\
\hline 23 & $251-247$ & 1.305 (1998) & $0.839(526)$ & 2.699 (1692) & $<1(20)$ & $76.3 \pm 7.0 \dagger$ & $13.3 \pm 0.3(40)$ & 1.91 \\
\hline 24 & $318-299$ & 1.312 (1998) & $0.923(790)$ & 1.249 (1069) & $3(20)$ & $183.8 \pm 13.2 \dagger$ & $12.8 \pm 0.2(100)$ & 1.60 \\
\hline 25 & $112-100$ & $1.318(1998)$ & $0.477(69)$ & $2.701(391)$ & $53(12)$ & $44.1 \pm 5.9$ & $13.8 \pm 0.5(5)$ & 1.19 \\
\hline 29 & $542-488$ & $1.125(1885)$ & $0.480(280)$ & 3.051 (1780) & $2(16)$ & $33.3 \pm 3.2 \dagger$ & $13.4 \pm 0.3(24)$ & 1.68 \\
\hline 30 & $542-488$ & $1.132(1885)$ & $0.052(19)$ & $0.142(52)$ & $88(13)$ & $78.2 \pm 21.1$ & - & \\
\hline 32 & $80-50$ & $1.146(1885)$ & $0.694(155)$ & $2.551(570)$ & $<1(11)$ & $65.3 \pm 18.6 \dagger$ & $12.6 \pm 0.6(6)$ & 1.53 \\
\hline 33 & $542-488$ & $1.153(1885)$ & $0.953(413)$ & $4.022(1744)$ & $<1(20)$ & $49.4 \pm 5.0 \dagger$ & $14.3 \pm 0.2(52)$ & 1.39 \\
\hline 34 & $542-488$ & $1.160(1885)$ & $0.296(36)$ & $3.598(437)$ & $<1(9)$ & $24.9 \pm 6.6 t$ & $13.9 \pm 1.6(3)$ & 2.72 \\
\hline 36 & $542-488$ & 1.167 (1885) & $1.268(79)$ & $2.372(148)$ & $<1(9)$ & $115.9 \pm 28.0 \dagger$ & $13.9 \pm 0.1(2)$ & 0.16 \\
\hline 37 & $80-50$ & $1.181(1885)$ & 3.009 (1367) & 3.306 (1502) & $2(20)$ & $201.9 \pm 11.5 t$ & $13.5 \pm 0.2(106)$ & 1.63 \\
\hline 38 & $444-416$ & $1.188(1885)$ & $2.790(1415)$ & $2.622(1330)$ & $<1(20)$ & $237.3 \pm 14.7 \dagger$ & $13.1 \pm 0.2(100)$ & 1.57 \\
\hline 39 & $444-416$ & $1.195(1885)$ & $1.282(426)$ & $1.664(553)$ & $<1(18)$ & $164.0 \pm 18.5 \dagger$ & $13.1 \pm 0.4(18)$ & 1.67 \\
\hline 42 & $2500-1600$ & $1.202(1885)$ & 3.017 (169) & $3.357(188)$ & $<1(4)$ & $174.5 \pm 56.5 \dagger$ & $14.1 \pm 0.9(5)$ & 1.92 \\
\hline 43 & $542-488$ & 1.209 (1885) & $0.818(478)$ & 4.463 (2609) & $<1(20)$ & $45.3 \pm 6.0 \dagger$ & $13.7 \pm 0.2(53)$ & 1.31 \\
\hline 44 & $542-488$ & $1.216(1885)$ & $0.093(8)$ & $0.865(74)$ & $16(3)$ & $24.9 \pm 9.3$ & $14.2 \pm 0.0(1)$ & \\
\hline 45 & $542-488$ & $1.223(1885)$ & $0.877(302)$ & $1.984(683)$ & $<1(8)$ & $90.0 \pm 32.2 t$ & $12.0 \pm 0.4(10)$ & 1.29 \\
\hline 46 & $2500-1600$ & $1.229(1885)$ & $0.913(681)$ & $1.163(867)$ & $<1(20)$ & $163.5 \pm 14.5 \dagger$ & $13.4 \pm 0.1(100)$ & 1.16 \\
\hline 48 & $2500-1600$ & $1.236(1885)$ & $1.953(1563)$ & $1.803(1443)$ & $<1(20)$ & $251.7 \pm 14.8 \dagger$ & $13.4 \pm 0.1(101)$ & 1.18 \\
\hline 49 & $2500-1600$ & $1.243(1885)$ & $0.986(599)$ & $1.625(987)$ & $<1(20)$ & $136.1 \pm 11.7 \dagger$ & $13.2 \pm 0.1(77)$ & 1.28 \\
\hline 50 & $2500-1600$ & $1.250(1885)$ & $1.982(1545)$ & $2.450(1910)$ & $2(20)$ & $184.7 \pm 10.1 \dagger$ & $13.4 \pm 0.1(110)$ & 1.50 \\
\hline 51 & $2500-1600$ & $1.257(1885)$ & 1.479 (1264) & 3.773 (3224) & $<1(20)$ & $93.9 \pm 6.7 \dagger$ & $13.4 \pm 0.1(101)$ & 1.15 \\
\hline 52 & $2500-1600$ & $1.264(1885)$ & $0.759(603)$ & 1.375 (1092) & $1(20)$ & $129.7 \pm 9.8 \dagger$ & $12.8 \pm 0.2(61)$ & 1.35 \\
\hline 53 & 2500-1600 & 1.178 (1924) & $0.042(38)$ & $0.048(43)$ & $100(18)$ & $201.4 \pm 45.2$ & $13.0 \pm 0.5(15)$ & 1.88 \\
\hline 54 & $2500-1600$ & $1.182(1924)$ & $1.986(801)$ & $1.539(621)$ & $3(20)$ & $293.7 \pm 23.2 \dagger$ & $13.1 \pm 0.2(106)$ & 1.64 \\
\hline 55 & $100-65$ & 1.187 (1924) & $0.343(124)$ & $1.838(665)$ & $<1(19)$ & $48.6 \pm 7.5 \dagger$ & $11.7 \pm 0.9(10)$ & 3.00 \\
\hline 58 & $145-100$ & 1.191 (1924) & $0.552(323)$ & 2.747 (1606) & $15(20)$ & $47.9 \pm 4.1 \dagger$ & $13.8 \pm 0.2(113)$ & 1.95 \\
\hline 59 & 100-65 & 1.195 (1924) & $0.169(118)$ & $0.860(601)$ & $92(20)$ & $45.9 \pm 4.8$ & $13.6 \pm 0.2(67)$ & 1.69 \\
\hline 60 & $1600-1000$ & 1.199 (1924) & $0.478(430)$ & $0.424(382)$ & $32(20)$ & $259.8 \pm 19.8$ & $12.8 \pm 0.1(115)$ & 1.40 \\
\hline 61 & $>2500$ & $1.203(1924)$ & $1.456(766)$ & $1.363(717)$ & $38(20)$ & $247.6 \pm 14.8$ & $12.8 \pm 0.2(109)$ & 1.81 \\
\hline 62 & $1600-1000$ & 1.207 (1924) & $2.156(932)$ & $1.855(802)$ & $<1(20)$ & $258.2 \pm 21.8 \dagger$ & $13.0 \pm 0.1(116)$ & 1.48 \\
\hline 63 & $444-416$ & $1.211(1924)$ & 2.129 (939) & $1.757(775)$ & $2(20)$ & $276.8 \pm 19.6 \dagger$ & $12.0 \pm 0.1(108)$ & 1.50 \\
\hline 64 & $161-130$ & 1.215 (1924) & 2.559 (884) & 2.255 (779) & $<1(20)$ & $299.1 \pm 38.5 \dagger$ & $11.8 \pm 0.2(105)$ & 1.97 \\
\hline 65 & $245-237$ & 1.219 (1924) & $0.941(266)$ & 2.297 (649) & $<1(15)$ & $80.6 \pm 19.9 \dagger$ & $13.2 \pm 0.5(22)$ & 2.14 \\
\hline 67 & $245-237$ & 1.223 (1924) & $0.979(364)$ & 4.609 (1714) & $13(20)$ & $50.8 \pm 3.3$ & $14.0 \pm 0.2(105)$ & 1.79 \\
\hline 68 & $161-130$ & $1.227(1924)$ & $0.682(216)$ & 3.545 (1122) & $78(20)$ & $46.2 \pm 3.7$ & $13.5 \pm 0.2(119)$ & 1.76 \\
\hline
\end{tabular}

${ }^{a}$ All numerical values for stratigraphic ages assigned following Gradstein et al. (2012). ${ }^{\mathrm{b}} \rho \mathrm{s}=$ spontaneous track density; pi = induced track density; $\rho D=$ glass-dosimeter track density. Numbers in parentheses show the number of tracks counted in determining all track densities. c Probability that all single- grain ages belong to a single population (Galbraith 2005). ${ }^{d}$ Central age (Galbraith 2005), used for samples containing a significant spread in single-grain ages $\left.\left(P \chi^{2}\right)<5 \%\right)$, is denoted with $\dagger$, otherwise the pooled age is quoted. All ages were calculated using the zeta calibration approach of Hurford \& Green (1983), using zeta values for CN5 glass of 380.4 \pm 5.7 (samples GC1113-1 to -52); $392.9 \pm 7.4$ (samples GC1113-53 to 68). All errors quoted at $\pm 1 \sigma$. All analytical details are as provided in Supplementary File S1. ${ }^{\mathrm{e} N u m b e r s}$ in parentheses show the number of track lengths measured. ${ }^{\mathrm{f}}$ Standard deviation of the track-length distribution. 
The chlorine content exerts a critical influence on fission-track annealing kinetics in apatite. Measuring chlorine is essential to obtain both improved accuracy and precision in the timing and magnitude of thermal events. Chlorine compositions were determined by an electron microprobe (see Supplementary File S2) for all individual apatite grains analysed (i.e. all grains in which fission-track ages were determined or lengths were measured).

Measured fission-track ages vary between $24.9 \pm 6.6 \mathrm{Ma}$ and $299.1 \pm 38.5 \mathrm{Ma}$, with most samples (c. 80\%) yielding ages less than $200 \mathrm{Ma}$ (Table 2). Apatite fission-track ages less than $300 \mathrm{Ma}$ in samples of Precambrian basement or early Palaeozoic metasediments show that the samples must have been much hotter than their present-day temperature at some time during the last $300 \mathrm{Ma}$.

Youngest apatite fission-track ages (<50 Ma) are generally found in coastal locations, while inland samples give consistently older ages (up to c. 300 Ma; Fig. 7). In addition to the thermal history, measured fission-track ages are sensitive to depositional ages, as well as external factors, such as the composition of apatite within each sample. Thus, regional variation is better described by looking at palaeotemperatures within individual palaeothermal episodes, as discussed in Section 4.5. Mean track lengths are generally between 12 and $14 \mathrm{~mm}$, with a small number of samples giving higher values (towards c. 15 $\mu \mathrm{m}$ ) and lower values (towards c. $11 \mu \mathrm{m}$; Fig. 8A; Table 2). Initial assessment of these data suggests that they are dominated by the late Palaeozoic and later history, and retain little trace of earlier events.

The AFTA data define a broadly consistent trend of mean track lengths versus apatite fission-track ages (Fig. 8A), where longest mean track lengths correspond to the youngest ages and the mean track length decreases as ages increase. While this trend resembles the classic 'boomerang' trend (Green 1986), typical of a suite of samples affected by a single dominant palaeothermal episode, the data show much more dispersion, suggesting a more complex history involving a series of discrete cooling episodes. Despite this complexity, the overall trend in Fig. 8A suggests that most samples across the region have undergone a similar style of thermal history involving a series of cooling episodes (Fig. 8A), with the magnitude of individual events varying across the region. Extraction of thermal history information from the AFTA data and subsequent synthesis has, therefore, been carried out on this basis. As none of the Precambrian samples give fission-track ages in excess of $300 \mathrm{Ma}$, data from these samples were interpreted by reference to the base of the Phanerozoic at $542 \mathrm{Ma}$.

AFTA data from the Wandel Sea Basin show a similar range to those from North-East Greenland Japsen et al. in press), in an area immediately south and overlapping with the study region (Fig. 8B). However, the Wandel Sea Basin samples plot consistently towards longer mean track lengths, particularly at younger ages.

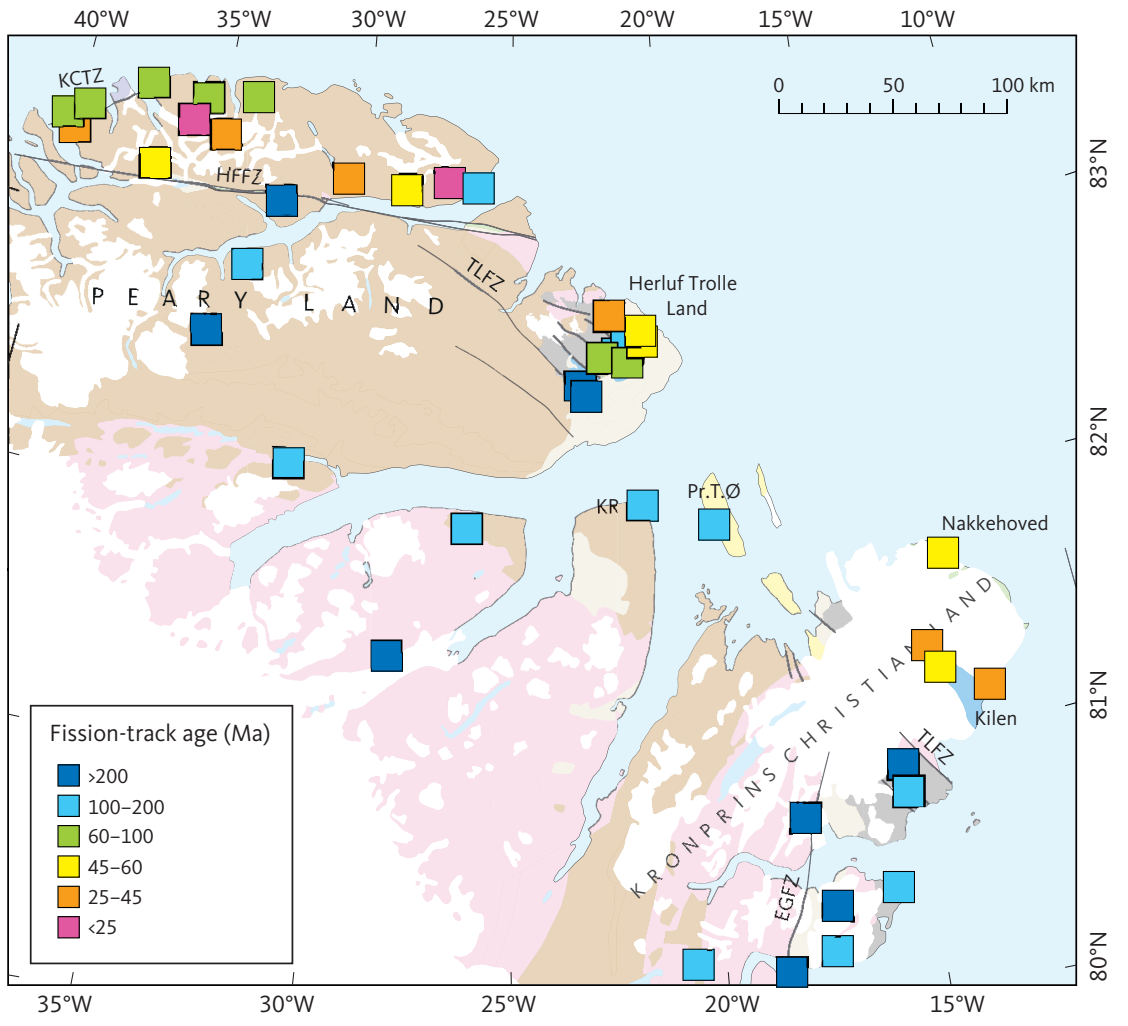

Fig. 7 Apatite fission-track ages in outcrop samples from eastern North Greenland (data in Table 2). Youngest ages $<60$ Ma are focussed along the north coast, while older ages are found in inland samples. EGFZ: East Greenland Fracture Zone. HFFZ: Harder Fjord Fault Zone. KCTZ: Kap Canon Thrust Zone. KR: Kap Rigsdagen. Pr.T.Ø: Prinsesse Thyra $\varnothing$. TLFZ: Trolle Land Fault Zone. Geology legend in Fig. 4. 


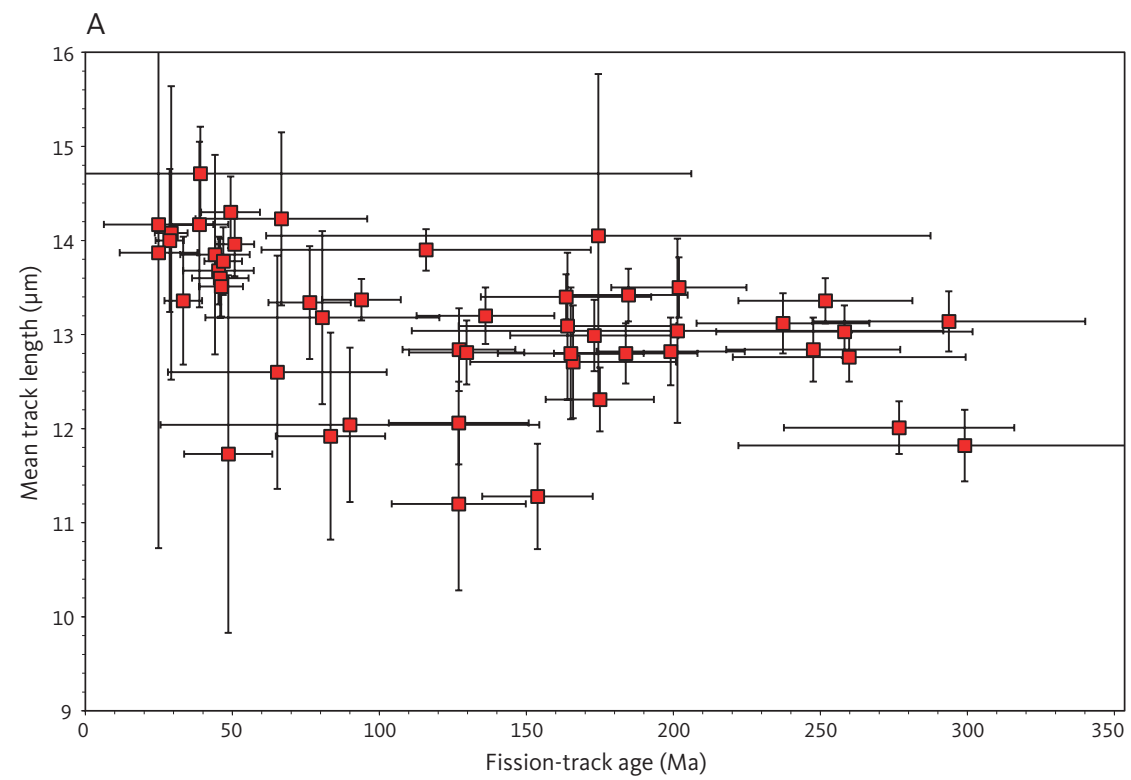

Fig. 8 Relationship between the mean track length and fission-track age. A: Outcrop samples from eastern North Greenland (this study). Error bars are shown as \pm 2 sigma. B: Results from this study compared with those from North-East Greenland (Japsen et al. in press). Ages span a similar range in both regions. However, data from this study are characterised by higher mean track lengths than those from NorthEast Greenland, which probably reflects the lower degree of Miocene cooling in samples from this study. Error bars are omitted for clarity.

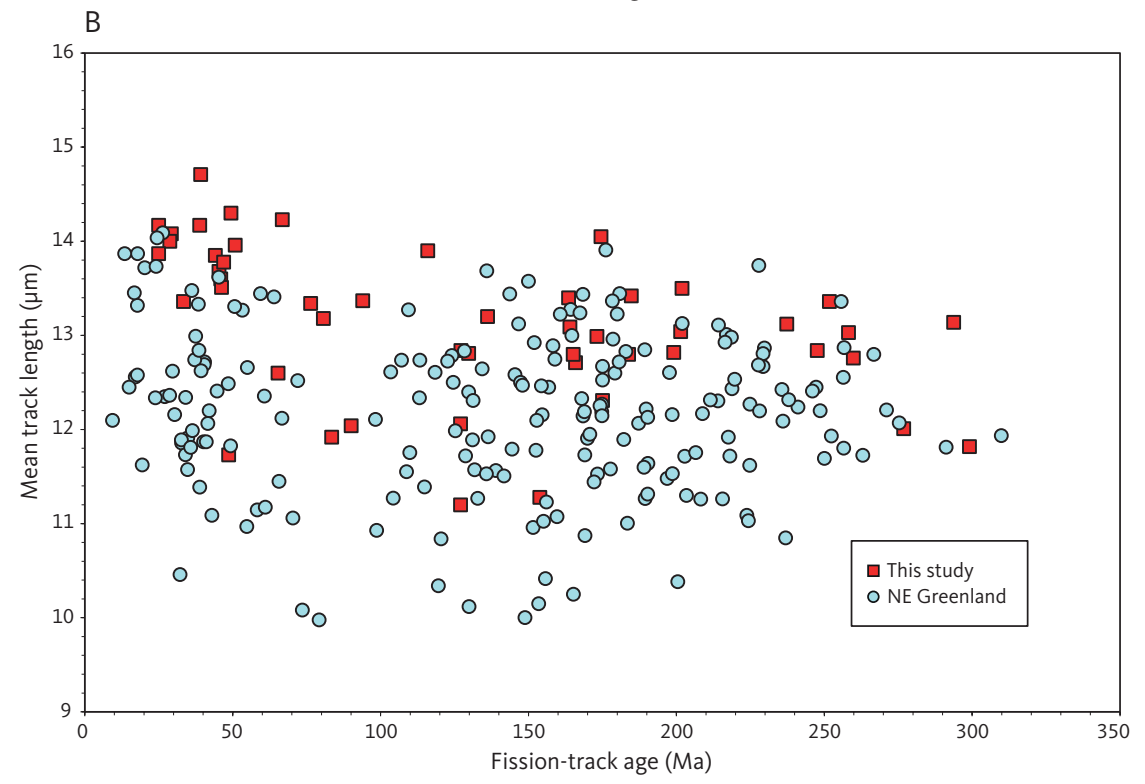

This probably reflects a reduced impact of Neogene cooling in the samples analysed. This is consistent with lower summit heights in the study region, and therefore, less pronounced Neogene uplift and incision.

\subsection{Thermal history interpretation based on AFTA data}

3.2.1 Principles of thermal history interpretation The techniques of extracting thermal history constraints from AFTA data are discussed in detail elsewhere (Green \& Duddy 2012; Green et al. 2013). In brief, fission tracks are formed continuously through time by spontaneous fission of ${ }^{238} \mathrm{U}$ atoms and accumulate at a rate determined by radioactive decay laws. Tracks form within a narrow range of lengths (between c.15 and $17 \mathrm{~mm}$ ). As an apatite grain is heated, tracks are shortened at a rate that depends on the prevailing temperature. The kinetics of annealing are such that temperature dominates over time. In a sample that has been heated to a maximum palaeotemperature and then cooled, almost all of the tracks formed during the heating phase are shortened to the same length. If the sample remains at lower temperatures, tracks formed after cooling will subsequently undergo less shortening compared with those formed prior to the onset of cooling, resulting in two distinct populations of tracks. The mean length of the shorter population is determined by the maximum palaeotemperature, while the proportion of short vs. long tracks will be determined by the ratio of the time before and after the onset of cooling. If the sample is re-heated to a peak palaeotemperature that is lower than the previous peak, and then cools again, tracks formed prior to the maximum are unaffected but tracks formed after cooling from the earlier maximum will be shortened to a degree determined by the peak palaeotemperature in 


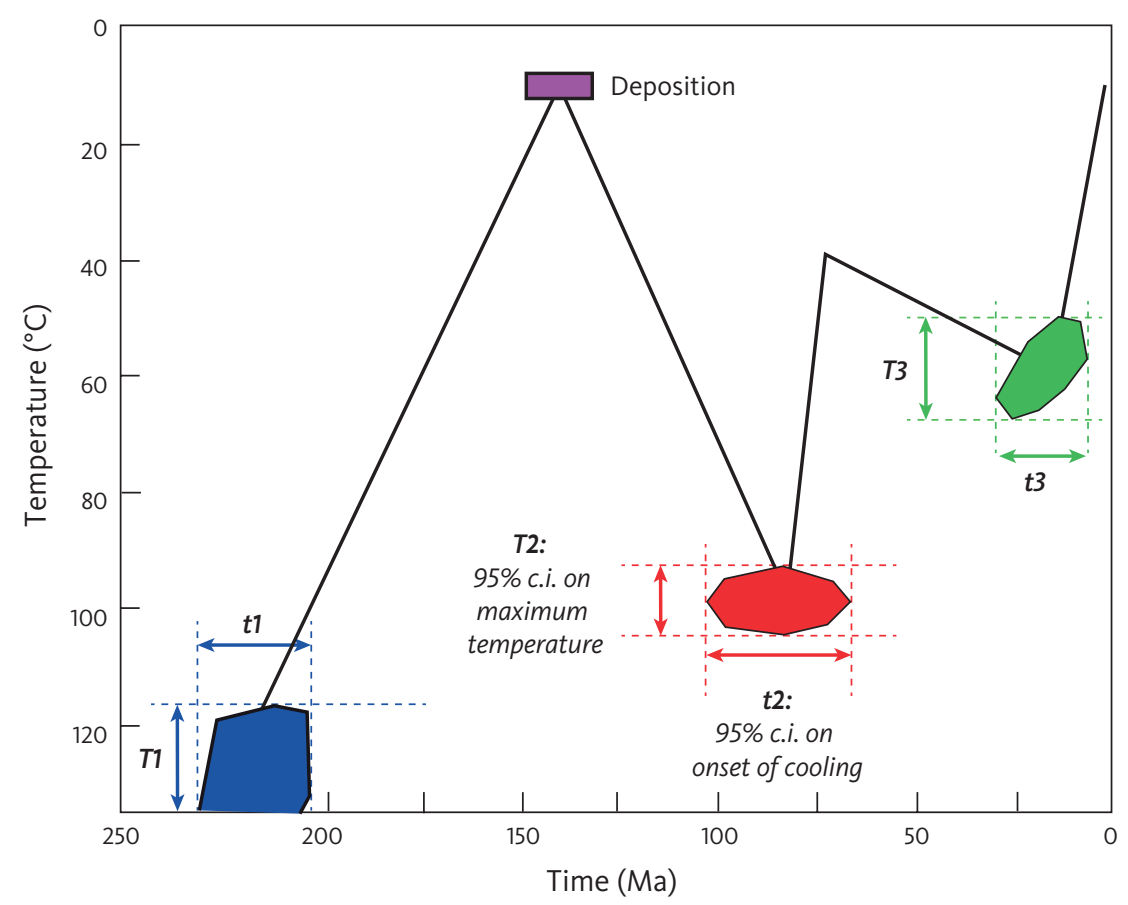

Fig. 9 Illustration of thermal history solutions extracted from AFTA data. Results are presented in terms of up to three palaeothermal episodes, that is, times when a rock sample was hotter than it is today. Note that the palaeotemperature constraint $\mathrm{T} 1$ is a minimum estimate because this is the event in which the apatites begin to retain tracks. In most situations, three events are the most that can be defined from AFTA due to various factors, including the natural spread in track lengths of a single population of tracks and the rapid decrease in the rate of annealing across the range from c. $110^{\circ} \mathrm{C}$ to below $60^{\circ} \mathrm{C}$. $\mathbf{t 1}, \mathbf{t} 2$ and $\mathbf{t 3}$ : time intervals during which cooling from the peak palaeotemperature began. T1, T2 and T3: palaeotemperature intervals. c.i.: confidence interval. Colours are used to illustrate attribution to regional episodes, although those used here are purely schematic. the second heating event. This results in two generations of tracks with different lengths, which allows definition of two episodes of heating and cooling, if the two events are sufficiently separated in temperature and time. In some cases, three episodes might be resolved in a similar fashion, while definition of four episodes of cooling may be possible under rare circumstances.

As AFTA data are dominated by the maximum palaeotemperature the data preserve no evidence of the history prior to the onset of cooling. For similar reasons, the history between successive cooling episodes cannot be resolved. Therefore, it is not possible to constrain the entire thermal history from the beginning of track retention. Instead, we define the maximum palaeotemperature and subsequent palaeothermal peaks within an overall framework of episodic heating and cooling (Fig. 9), assuming heating and cooling rates of $1{ }^{\circ} \mathrm{C} / \mathrm{Ma}$ and $10^{\circ} \mathrm{C} / \mathrm{Ma}$, respectively. An order of magnitude change in heating rate is equivalent to around a $10^{\circ} \mathrm{C}$ difference in palaeotemperature required to produce a given degree of annealing.

As explained in detail elsewhere, the combination of AFTA with geological evidence has provided abundant evidence that thermal histories involving episodic heating and cooling are more realistic than slow, monotonic cooling (Green \& Duddy 2012; Green et al. 2013, 2018). This conclusion is based on studies in which AFTA data provide evidence of cooling and exhumation, while times when underlying rocks were at the surface are identified from remnants of the former sedimentary cover. Such situations provide evidence of repeated burial and exhumation, and are generally applicable in a wide variety of settings (Green et al. 2013, 2017).
Thermal history solutions are represented by $95 \%$ confidence limits on the maximum (or peak) palaeotemperature and on the time at which cooling from that palaeotemperature began (Fig. 9). The parameters are extracted from data in each sample by comparing measured AFTA parameters (fission-track ages and track lengths) with those predicted from candidate thermal histories, involving up to three episodes of heating and cooling. By varying the magnitude of maximum palaeotemperature and the onset of cooling in each episode, the range of temperature-time combinations giving predictions consistent with the measured data and within 95\% confidence limits can be defined using the likelihood theory based on principles similar to those outlined by Gallagher (1995). Where three episodes are defined, the earliest episode is constrained primarily from the fission-track age data and represents the episode in which samples cool below c. $110^{\circ} \mathrm{C}$ and began to retain tracks, while the two more recent episodes are defined principally from the distribution of track lengths.

\subsubsection{Thermal history interpretation: results}

Detailed thermal history interpretation of the AFTA data in each sample is provided in Supplementary File S2. As explained therein, AFTA data in almost all samples show clear evidence of higher temperatures after deposition (or in Phanerozoic times for samples of Precambrian basement). Thermal history solutions derived from the AFTA data in each sample, in terms of the maximum palaeotemperature and the timing of cooling in a number of discrete episodes, are summarised in Table 3. 


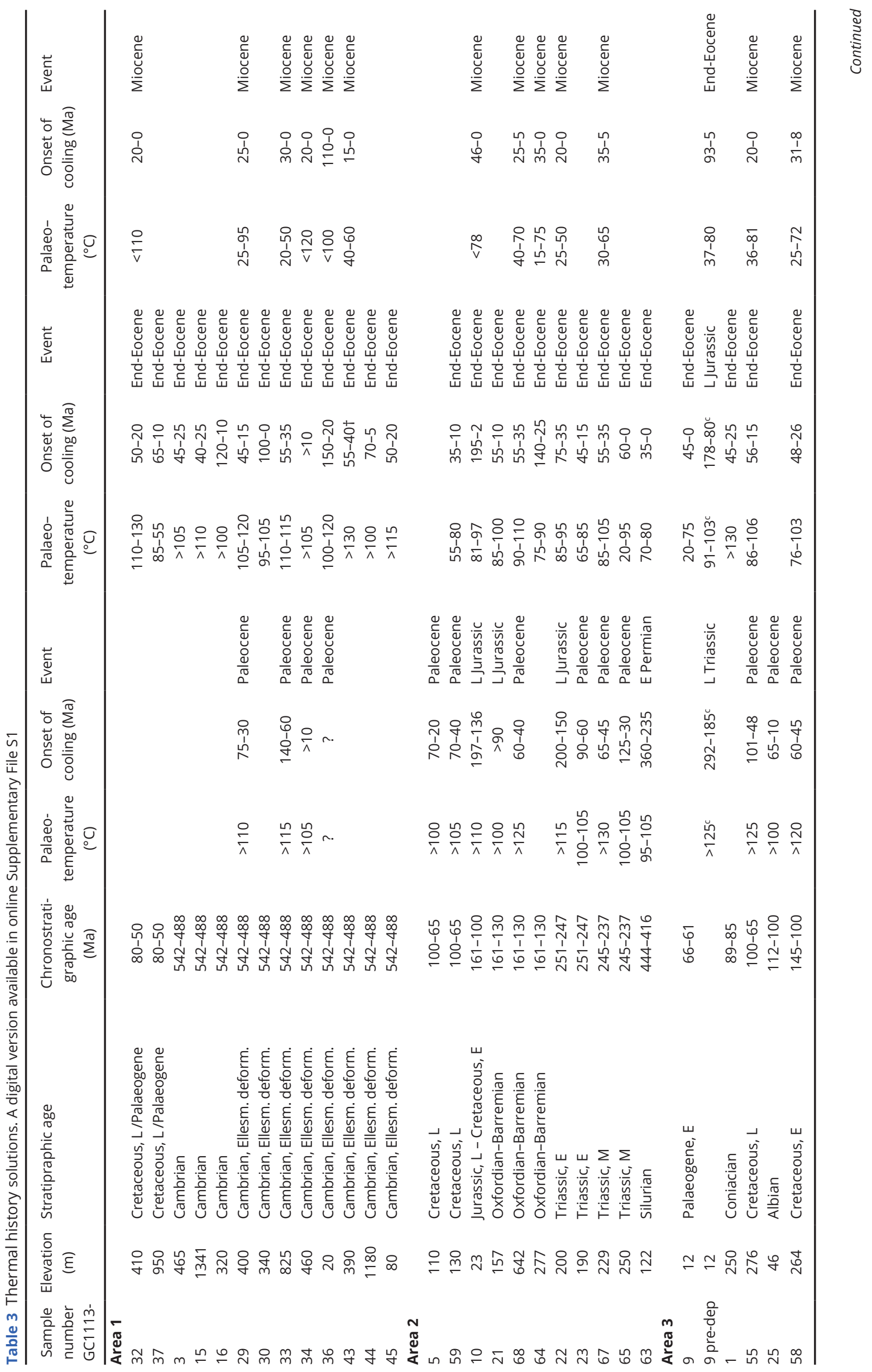




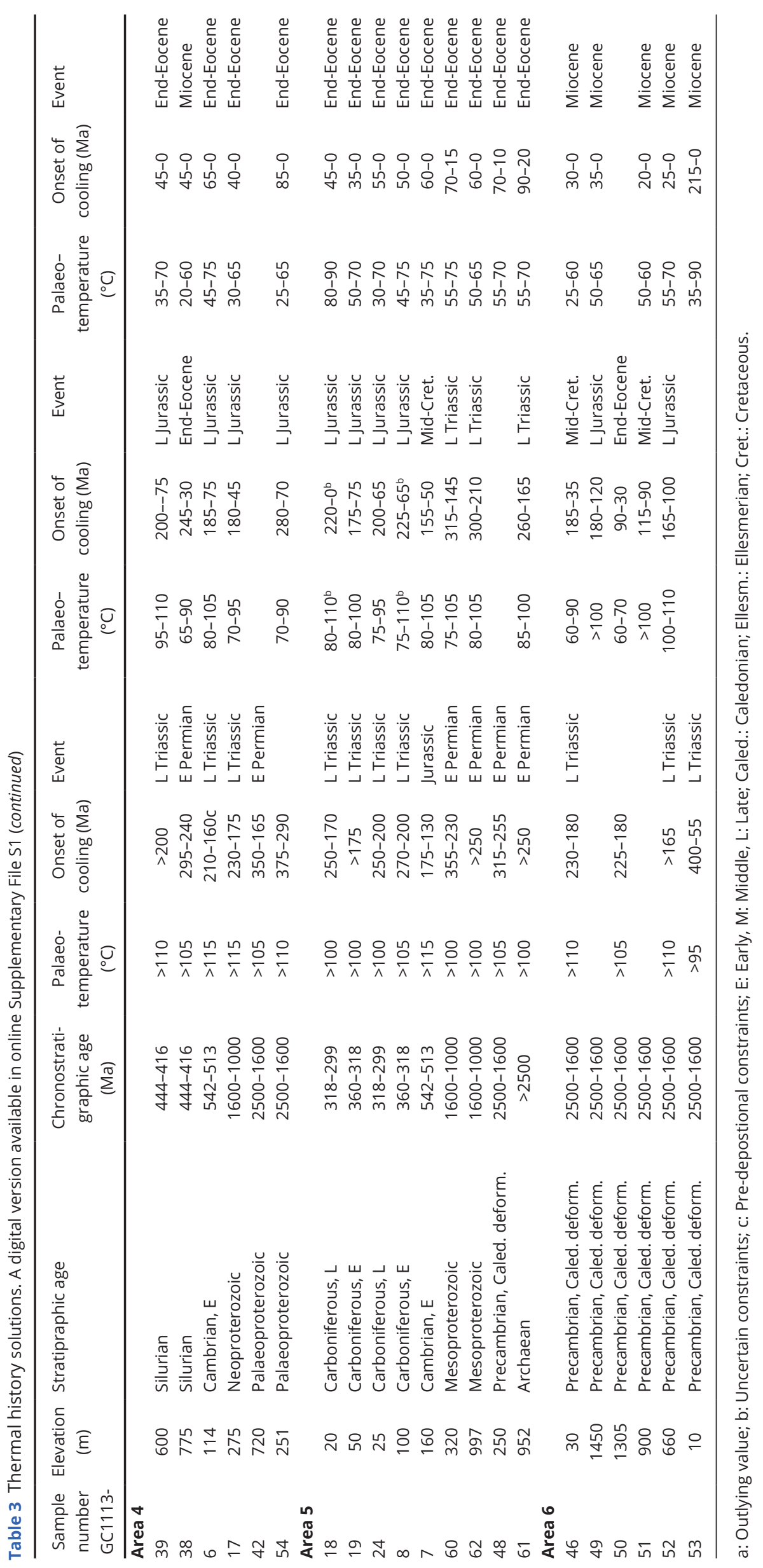


In most of the samples analysed, the AFTA data require at least three episodes of heating and cooling, while in a small number of samples only two episodes are required to explain the data. Definition of two palaeothermal episodes represents a typical level of resolution that can be achieved from AFTA. Generally, the earlier episode would be defined by the fission-track age data and possibly the shorter track lengths, while the more recent episode would be defined by the shortening of the main mode of the track length distribution. However, where the palaeotemperatures in each episode are sufficiently well separated, three episodes can be resolved. In samples GC1113-19 and -24, the earliest episode produces total annealing of all tracks, a later event leads to shortening of tracks formed after the initial cooling to lengths around 10-11 mm, and another later event then shortens tracks formed after the second episode to lengths around 13 $\mathrm{mm}$. The ability to resolve three episodes often depends on the quality of the data, with 100 track length measurements normally required to provide a confident conclusion. In most samples from this study, this criterion was met. Nevertheless, a random variation in measured parameters can lead to the failure of identifying three episodes in some samples, while nearby samples provide a clear resolution. Thus, in some cases, the quoted thermal history solutions may represent the combined effects of unresolved multiple cooling episodes. This is also particularly important at low temperatures $\left(<70^{\circ} \mathrm{C}\right)$, where differences in track length may be insufficient to allow multiple episodes to be resolved.

Synthesis of all data, as discussed in Section 3.3, suggests that at least seven discrete cooling episodes are required to explain the results from all samples. This emphasises the fact that AFTA data in individual samples, even in the most favourable circumstances, allow resolution of only three discrete episodes. The events that dominate the data in a given sample will be a function of the magnitude of each episode, the quality of the AFTA data and the spread of compositions present. Often, the highest $\mathrm{Cl}$ levels may reveal an earlier episode, for which the evidence has been overprinted by later events in the more sensitive, low-Cl apatites.

\subsection{Definition of major regional \\ palaeothermal episodes}

Figure 10 shows timing constraints (95\% confidence limits) on the onset of discrete cooling episodes in individual samples defined by AFTA (Fig. 9). Thermal history constraints for all samples are listed in Table 3. Samples are grouped into six geographic regions based on the general uniformity of the data within each of the regions (Areas 1-6; Fig. 6). Based on this uniformity of the data within each region and the evidence for regionally consistent thermal histories, we have sought to define the minimum number of regionally synchronous cooling episodes that can explain the results in all of these samples. Integration of results from all samples requires a total of seven discrete cooling episodes (vertical bars in Fig. 10; see also Table 4). The onset of cooling in each episode ranges from early Permian to middle to late Miocene. These intervals represent the times at which cooling began in each episode, and we do not suggest that cooling was restricted to these intervals. Note that in some cases, the estimated onset of cooling pre-dates the depositional age of the sample. This indicates cooling of the apatite in sediment provenance regions, prior to deposition in the host sample.

Pre-Cenozoic episodes are expressed almost exclusively at inland locations (Areas 4 and 5 together with locations to the south in Area 6). Three Cenozoic episodes are focussed particularly in northern coastal locations (Areas 1-3).

Two constraints shown in Fig. 10 do not conform to the regional synthesis outlined above: (1) AFTA data in sample GC1113-43 (Precambrian) define an initial phase of cooling from $>110^{\circ} \mathrm{C}$, which began between 55 and $40 \mathrm{Ma}$. This falls between the two regional events that began at c. $60 \mathrm{Ma}$ and c. $35 \mathrm{Ma}$. (2) The earliest cooling episode defined in sample GC1113-16 began between 210 and $160 \mathrm{Ma}$, which is just outside the 225-210 Ma timing derived from the majority of samples. These isolated examples most likely represent statistical outliers or may reflect the difficulty in resolving multiple cooling episodes within AFTA data in individual samples. Further sampling in the region may help to resolve these issues.

We have allocated the timing constraints for individual samples to specific regional events, such that adjacent samples that show cooling from similar palaeotemperatures with consistent timing constraints are interpreted as a common episode. We seek to minimise the total number of episodes required. In this way, samples with quite broad constraints can still be allocated to specific regional events. For example, samples GC1113-33 and -34 both cooled from palaeotemperatures $>110^{\circ} \mathrm{C}$, but while the timing constraint in sample -33 is quite well defined (140-60 Ma), the timing in sample -34 is only defined as $>10 \mathrm{Ma}$. This is probably due to a combination of the low apatite yield (nine ages) and the young age (c. $25 \mathrm{Ma}$ ), and as a result, only three track lengths were measured. Given the proximity of both these samples, it seems reasonable to assume that both samples cooled in a common event, in this case the $60 \mathrm{Ma}$ cooling episode. This illustrates how data with quite broad constraints can still provide useful conclusions.

The results of this study could be interpreted in many different ways, and attempting to explain the data in terms of the smallest number of regionally synchronous cooling episodes may mask a more complex regional variation in thermal history. However, the synthesis 


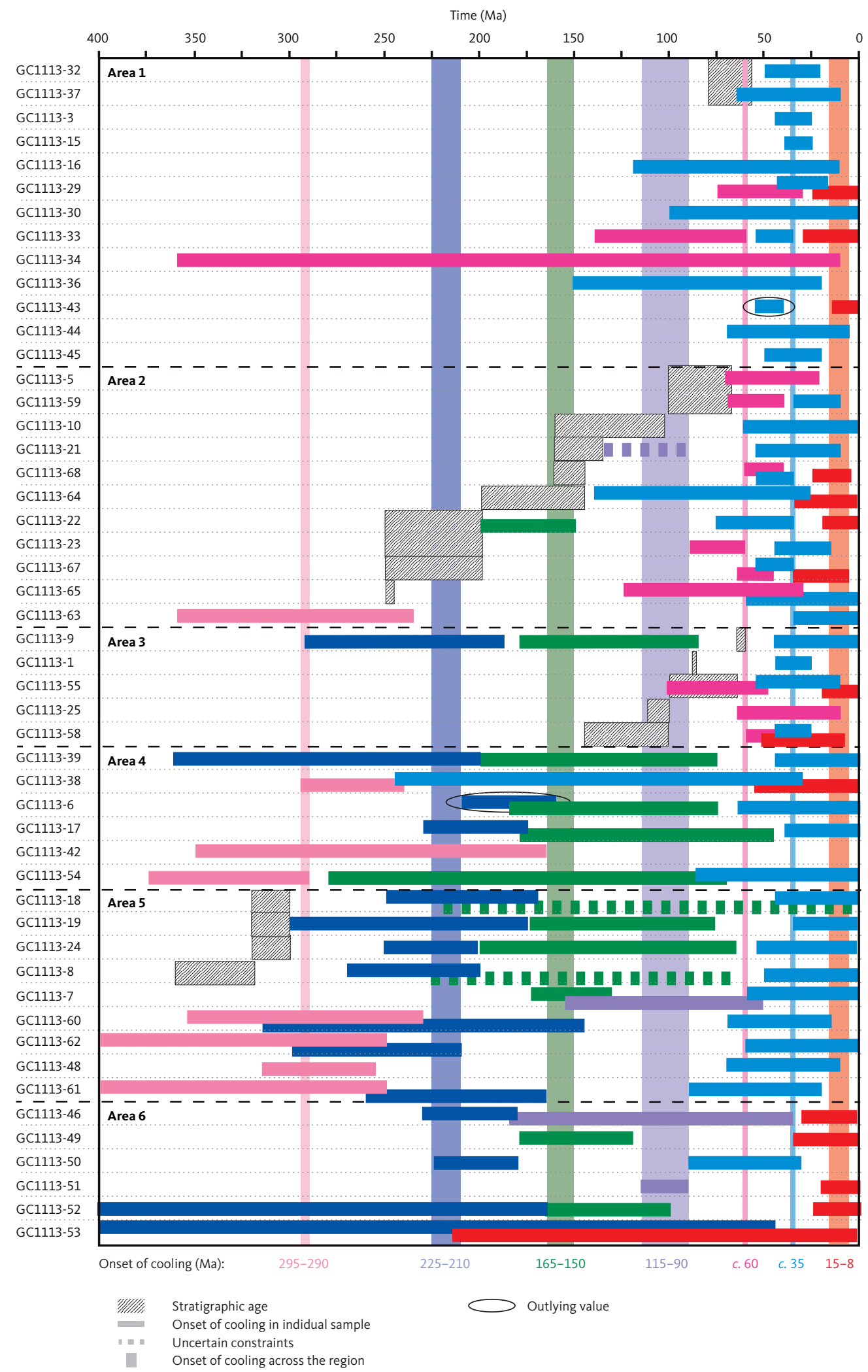

Fig. 10 Timing constraints on the onset of cooling for discrete cooling episodes derived from the AFTA in each outcrop sample. Thermal history solutions for each sample are listed in Table 3. Horizontal-shaded bars represent $95 \%$ confidence intervals on the time of cooling onset, as illustrated in Fig. 9. Samples are divided into six areas (Areas 1-6; Fig. 6). Assuming these results represent regionally synchronous cooling episodes, results across the entire region require seven separate episodes, as shown by vertical shaded columns. Constraints for the onset of each episode are listed at the bottom of the figure (see Table 4). Timing constraints for individual samples are assigned to a common regional event when adjacent samples cool from similar palaeotemperatures with consistent timings. In some cases, the estimated onset of cooling pre-dates the depositional age of the sample, indicating cooling of the apatites in sediment provenance regions prior to deposition in the host sample. 
Table 4 Intervals defining the onset of episodes of cooling based on AFTA data in all samples and the possible origin of the cooling during each episode

\begin{tabular}{lll}
\hline Onset of cooling (Ma) & Onset of cooling (chronostratigraphy) & Mechanism \\
\hline $295-290$ & Early Permian & Regional uplift and erosion \\
$225-210$ & Late Triassic & Regional uplift and erosion \\
$165-150$ & Late Jurassic & Regional uplift and erosion \\
$115-90$ & Mid-Cretaceous & Regional uplift and erosion \\
$\sim 60$ & Mid-Paleocene & Uplift and erosion related to compression in fault zones \\
$\sim 35$ & End-Eocene & Regional uplift and erosion, locally enhanced heating \\
$15-5$ & Middle to late Miocene & Regional uplift and erosion \\
\hline
\end{tabular}

Figure 10 displays the timing of onset of discrete cooling episodes in individual samples. Supplementary File S1 contains digital versions of Table 1 (sample details and additional information), Table 2 (AFTA data) and Table 3 (thermal history solutions). Supplementary File S2 contains Geotrack report with analytical details, basic AFTA data in individual samples and a discussion of thermal history solutions derived from AFTA data in each sample (Green 2014).

presented here provides a consistent framework for interpreting the underlying nature of each episode. As discussed earlier, it is important to remember that AFTA data in individual samples only reveal two or at best three dominant episodes, and in at least some of the samples described here, the results probably represent the unresolved effects of a larger number of episodes.

It is also important to realise that AFTA only constrains cooling from the palaeothermal peaks, and the thermal history in the interval between each cooling episode is not well constrained. A wide range of scenarios can, therefore, be invoked, involving cooling and reheating to a subsequent palaeothermal peak or prolonged stability between sequential cooling episodes. For all these reasons, definition of the thermal history in terms of a sequence of cooling episodes should be regarded as a general indication of the overall history, within the context of the cooling episodes defined from AFTA.

\subsection{Regional variation in palaeothermal episodes}

Palaeotemperatures for six of the seven palaeothermal episodes identified are mapped in Fig. 10, excluding samples from Area 6 in Fig. 6 (one episode is recognised only in a single sample from the region shown in Fig. 11). Here, we summarise the variation of palaeotemperatures in each episode and discuss the mechanisms responsible.

Early Permian palaeotemperatures around $100^{\circ} \mathrm{C}$ or above, from which cooling began between 295 and 290 $\mathrm{Ma}$, are identified in samples scattered across most of the study area, but predominantly in the interior away from the major fault zones (Fig. 11A). This is the earliest of the palaeothermal episodes recognised across the region, and as such, it is only recorded in areas where palaeotemperatures in subsequent episodes have remained sufficiently low as to not overprint it. Locations recording this episode, therefore, represent relatively stable areas, which have undergone less post-Permian heating and cooling than the surrounding regions. None of the samples in the region preserve evidence of remaining at temperatures below $100^{\circ} \mathrm{C}$ prior to the early Permian times, emphasising the magnitude of post-Palaeozoic palaeothermal effects across the entire region.

Late Triassic palaeotemperatures, from which cooling began between 225 and $210 \mathrm{Ma}$, occur predominantly in the centre of the study area and at south-eastern coastal locations (Fig. 11B). Maximum palaeotemperatures in this episode are in excess of $110^{\circ} \mathrm{C}$ for two samples in central locations and generally around $100^{\circ} \mathrm{C}$ or more on the south-eastern coast. As with the early Permian episode, Late Triassic cooling is only recorded in areas where palaeotemperatures in subsequent episodes have remained sufficiently low as to not overprint evidence of this episode.

Late Jurassic palaeotemperatures, from which cooling began between 165 and $150 \mathrm{Ma}$, are more variable than those in earlier events (Fig. 11C). Two samples cooled from $>110^{\circ} \mathrm{C}$ in this episode, which will have removed any evidence of earlier episodes. Other samples cooled from palaeotemperatures generally between 80 and $100^{\circ} \mathrm{C}$ in this episode. The extent of this episode is similar in broad terms to the early Permian and Late Triassic episodes but differs significantly from the three Cenozoic episodes. Only a single sample north of $79^{\circ} \mathrm{N}$ (Fig. 6) shows definite evidence of mid-Cretaceous cooling, which began between 115 and $90 \mathrm{Ma}$ (GC1113-17, not shown in Fig. 11). However, this episode is also defined in samples to the south (Area 6; Fig. 10). Evidence of cooling at this time is widespread in North-East Greenland (Japsen et al. in press).

Paleocene palaeotemperatures, from which cooling began at c. $60 \mathrm{Ma}$ (Fig. 11D), are focussed almost exclusively within the HFFZ and the TLFZ, as well as a single sample from Kilen.

End-Eocene palaeotemperatures, from which cooling began at c. $35 \mathrm{Ma}$, are recognised across almost the entire study area (Fig. 11E). Highest values (generally 
$>110^{\circ} \mathrm{C}$ ) are recognised not only in Peary Land, north of the HFFZ, but also at coastal locations south of the Wandel Sea Basin; lower values around $60-70^{\circ} \mathrm{C}$ are identified across the interior of the region. The dominance of this episode, and to some extent also the Paleocene episode, most likely masked the earlier episodes over much of the coastal region. The Permian and Triassic episodes are only recognised in regions where palaeotemperatures in Palaeogene events were sufficiently low. On this basis, we suggest it is likely that these earlier episodes were also felt across the Wandel Sea Basin, similar to events recognised in North-East Greenland (Japsen et al. in press).

Middle to late Miocene palaeotemperatures, from which cooling began between 15 and $5 \mathrm{Ma}$, are recognised mainly at coastal and near-coastal locations (Fig. 11F), and generally at locations where palaeotemperatures at $35 \mathrm{Ma}$ were around $100^{\circ} \mathrm{C}$ or more. In samples that cooled from lower palaeotemperatures at 35 $\mathrm{Ma}$, it is likely that by $10 \mathrm{Ma}$, these locations had cooled to temperatures too low to be resolved from AFTA data.

\section{Thermal history insights from maturity data}

A number of published studies provide further insights into the thermal history of the region. These are focussed mainly on thermal maturity studies, with some additional information provided by studies of diagenetic and mineralogical properties of rocks. Here, we review these published data in light of the regional thermal history framework derived from AFTA in the previous section. The various datasets combined provide a broadly consistent picture of the thermo-tectonic development of the region.

\subsection{Maturity of lower Palaeozoic strata}

Rasmussen \& Smith (2001) sampled conodonts within the lower Palaeozoic rocks across Kronprins Christian Land $\left(79-81^{\circ} \mathrm{N}\right)$ at the northernmost limit of the East Greenland Caledonides. They interpreted the conodont colour alteration index (CAI) to provide a measure of maximum burial temperature and, in turn, the thickness of overburden. The data showed a gradual and continuous increase across Kronprins Christian Land from CAI $3\left(110-200^{\circ} \mathrm{C}\right)$ in the west to $\mathrm{CAl} 5+\left(>300^{\circ} \mathrm{C}\right)$ in the east (Armstrong et al. 1994). They concluded that the predominant process defining the regional variation was loading by Caledonian thrust sheets. Their modelling of the thickness of the removed overburden, based on a palaeogeothermal gradient of $28^{\circ} \mathrm{C} / \mathrm{km}$, suggested that it increased from $3.9 \mathrm{~km}$ in the west to a maximum of $12.5 \mathrm{~km}$ beneath a thrust sheet in the easternmost part of the area. Rasmussen \& Håkansson (1996) reported a CAI value of 6 for one sample of Permian limestones from Prinsesse Ingeborg Halvø $\left(360-550^{\circ} \mathrm{C}\right)$. The sample may thus have reached these palaeotemperatures at any time since the Permian.

Paech \& Estrada (2018) reported VR levels of 6.1-8.5\% in rocks of probable Ordovician age in the Frigg Fjord and Kap Washington regions (Fig. 12), which indicate maximum palaeotemperatures $>300^{\circ} \mathrm{C}$. Our AFTA data provide no control on pre-Permian events, so no direct comparison with pre-Permian palaeothermal episodes is possible. However, early Permian cooling from $>110^{\circ} \mathrm{C}$ (Fig. 11A) would be consistent with palaeotemperatures in excess of $110^{\circ} \mathrm{C}$ in the early Palaeozoic.

\subsection{Maturity of Mesozoic-Palaeogene strata}

Published VR data for the Wandel Sea Basin region are summarised in Fig. 12. The data include (1) a comprehensive study of the thermal maturity of Mesozoic and Palaeogene sediments from the Wandel Sea Basin, which overlaps with our study area (Paech \& Estrada 2018); (2) a review of VR data (Håkansson et al. 1994) and (3) a recently published study of VR data from Kilen (Pedersen et al. 2018) that were not included in the review by Paech \& Estrada (2018). Maximum palaeotemperatures equivalent to the VR values in Fig. 12 are calculated based on the algorithm of Burnham \& Sweeney (1989).

Paech \& Estrada (2018) observed that Mesozoic sequences attain high-maturity levels (VR mostly $>2 \%$; equivalent to $>200^{\circ} \mathrm{C}$ ) within prominent fault zones, including the KCTZ, HFFZ and TLFZ (Fig. 12). These higher maturity levels are typically associated with an increase in deformation intensity evidenced by the occurrence of a weak cleavage. In many cases, sediments as young as Late Cretaceous show evidence of profound tectonism, including steep dips and faulting. Paech \& Estrada (2018) also noted that the high VR (up to $5.4 \%$ ) levels for the Kap Washington Group is associated with ductile deformation and magmatic activity. The maturity of Jurassic-Cretaceous sediments away from the major fault zones is relatively low, typically around $0.55 \%\left(\right.$ c. $\left.90^{\circ} \mathrm{C}\right)$, interpreted as reflecting heating due to regional burial.

Relatively flat-lying and undeformed Palaeogene units on, for example, Prinsesse Thyra $\varnothing$ and in Depotbugt (Croxton et al. 1980; Håkansson \& Pedersen 2015), contrast markedly with nearby, often intensely deformed Upper Cretaceous units that variously show steep dips, folding, faulting and, in some cases, thrusting. This contrast is supported by a major difference in maturity levels, with VR values around $0.55 \%$ in Palaeogene units and $2 \%$ or more in Cretaceous units within the major fault zones. Paech \& Estrada (2018), therefore, concluded that the major phase of tectonism that resulted in such high maturity levels occurred around the Cretaceous-Cenozoic boundary. However, the 


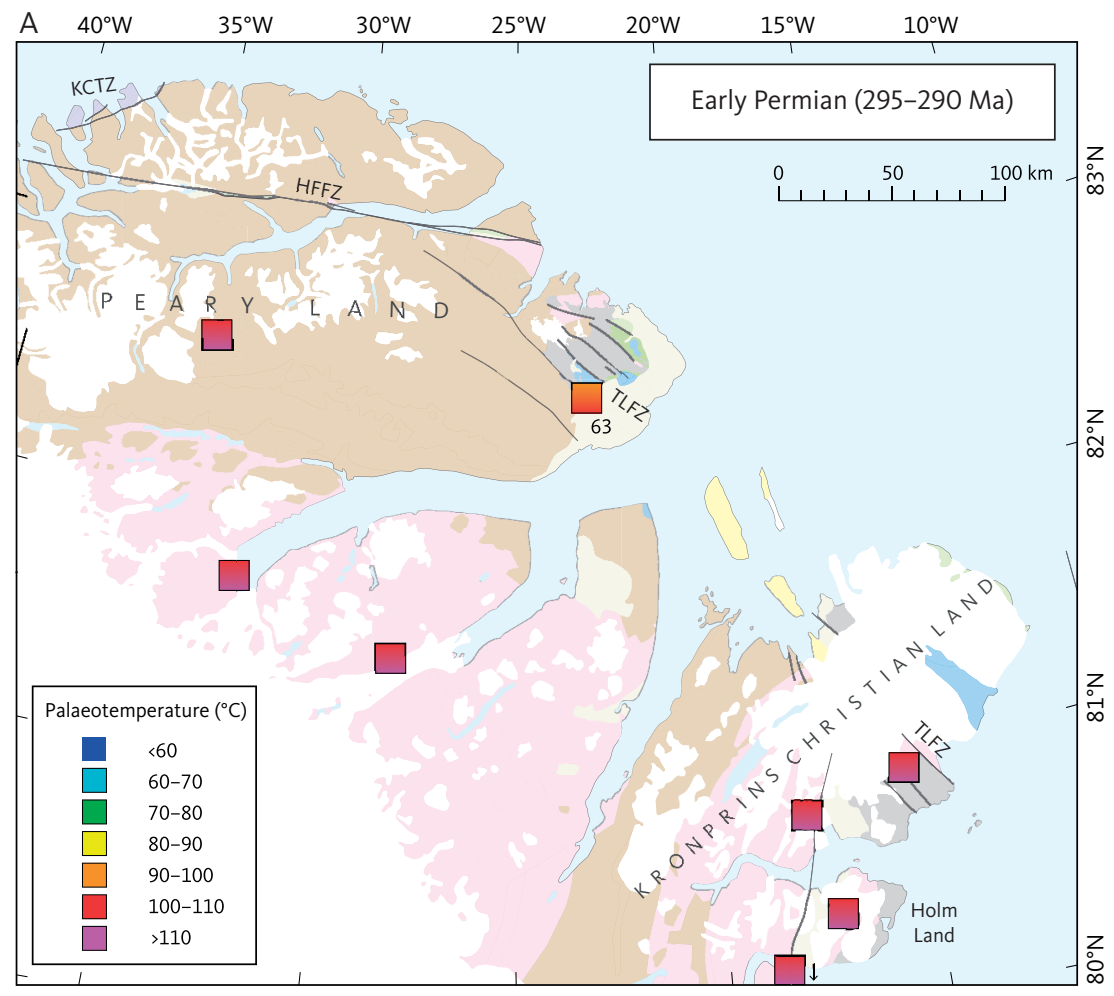

Fig. 11 Palaeotemperatures derived from AFTA. A: Early Permian (295-290 Ma). B: Late Triassic (225-210 Ma). C: Late Jurassic (165-150 Ma). D: Paleocene (c. $60 \mathrm{Ma}$ ). E: End-Eocene (c. $35 \mathrm{Ma}$ ). F: Middle to late Miocene (15-5 Ma). Palaeotemperature for the mid-Cretaceous episode (115-90 $\mathrm{Ma}$ ) is not shown as only one sample falls within the map frame. The small arrow in the lower right corner of $\mathrm{A}, \mathrm{E}$ and $\mathrm{F}$ indicates sample GC1113-48, which is located just south of the figure frame. Geology legend in Fig. 4. Numbers next to AFTA samples denote sample numbers. HFFZ: Harder Fjord Fault Zone. KCTZ: Kap Canon Thrust Zone. KR: Kap Rigsdagen. Pr.T.Ø: Prinsesse Thyra $\varnothing$. TLFZ: Trolle Land Fault Zone.

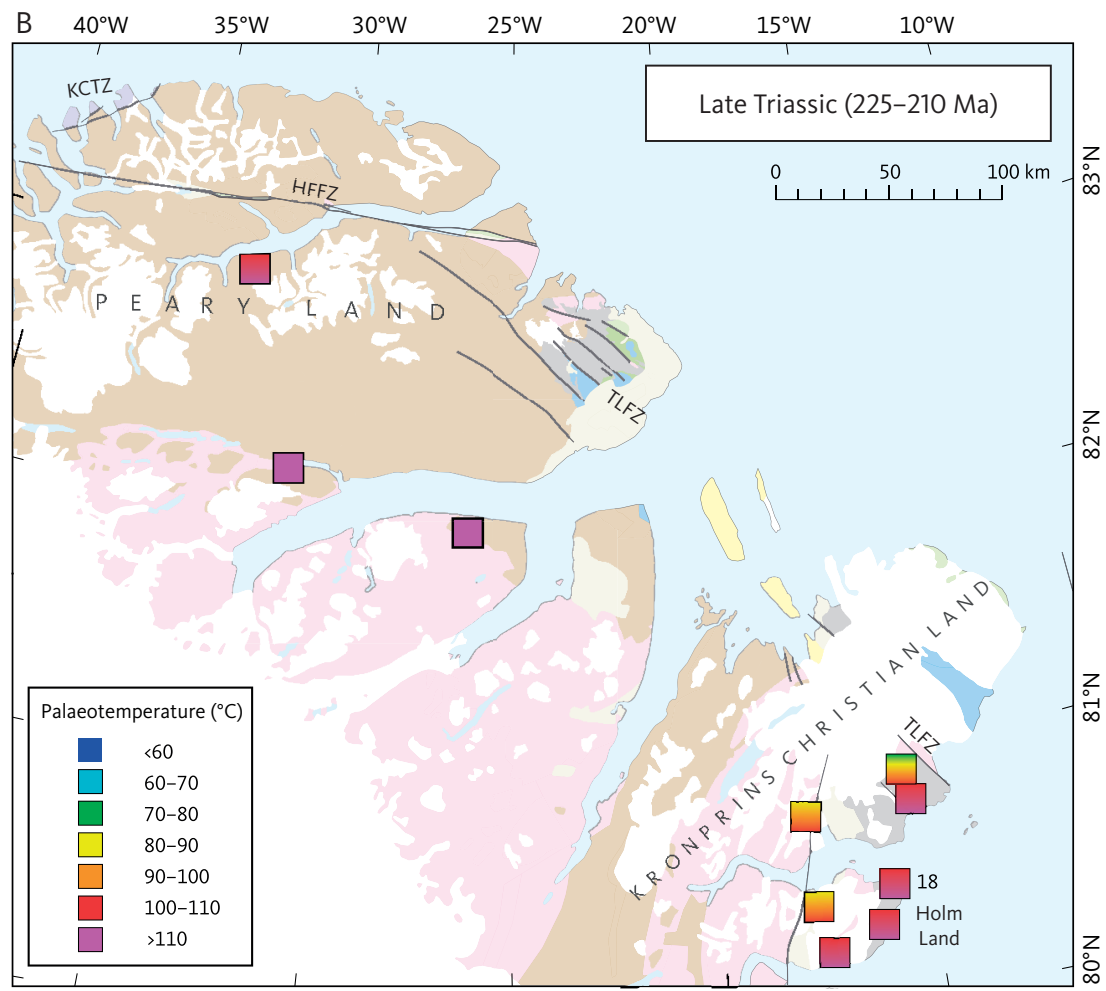

maturity of the Palaeogene units is very similar to those in Mesozoic units away from the fault zones, and Palaeogene units do not occur within the zones of intense tectonism. It is, therefore, possible that the regional base level of maturity reflects heating after deposition of the Thyra $\varnothing$ Formation.
Extremely high maturity levels (>7\%) were reported in the Upper Cretaceous Nakkehoved Formation exposed on the north coast of Kronprins Christian Land (Håkansson et al. 1994), corresponding to maximum palaeotemperatures well above $250^{\circ} \mathrm{C}$ (the limit at which palaeotemperatures can be calculated by VR). 


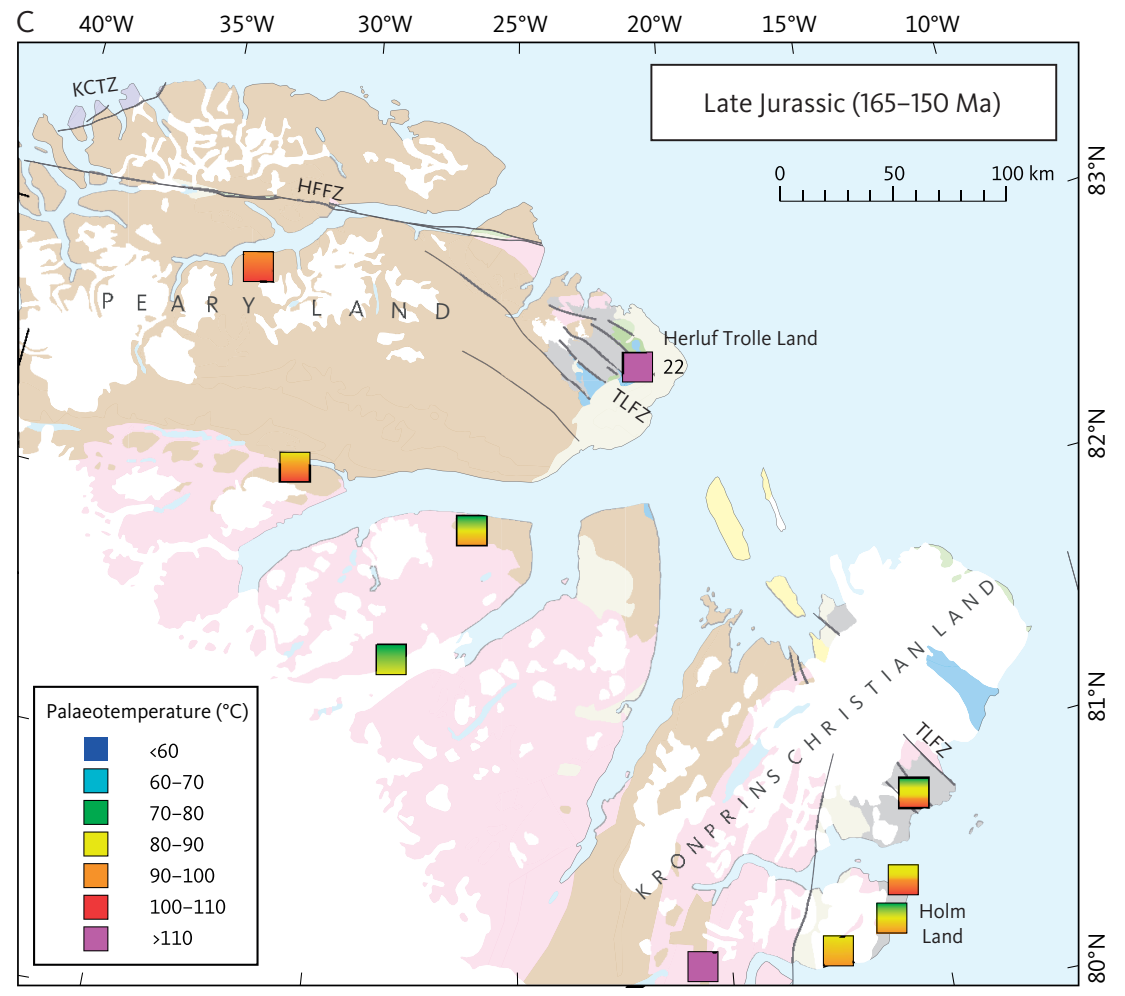

Fig. 11 (Continues) Palaeotemperatures derived from AFTA. A: Early Permian (295290 Ma). B: Late Triassic (225-210 Ma). C: Late Jurassic (165-150 Ma). D: Paleocene (c. $60 \mathrm{Ma}$ ). E: End-Eocene (c. $35 \mathrm{Ma}$ ). F: Middle to late Miocene (15-5 Ma). Palaeotemperature for the mid-Cretaceous episode (115-90 Ma) is not shown as only one sample falls within the map frame. The small arrow in the lower right corner of $A, E$ and $F$ indicates sample GC1113-48, which is located just south of the figure frame. Geology legend in Fig. 4. Numbers next to AFTA samples denote sample numbers. HFFZ: Harder Fjord Fault Zone. KCTZ: Kap Canon Thrust Zone. KR: Kap Rigsdagen. Pr.T.Ø: Prinsesse Thyra Ø. TLFZ: Trolle Land Fault Zone.

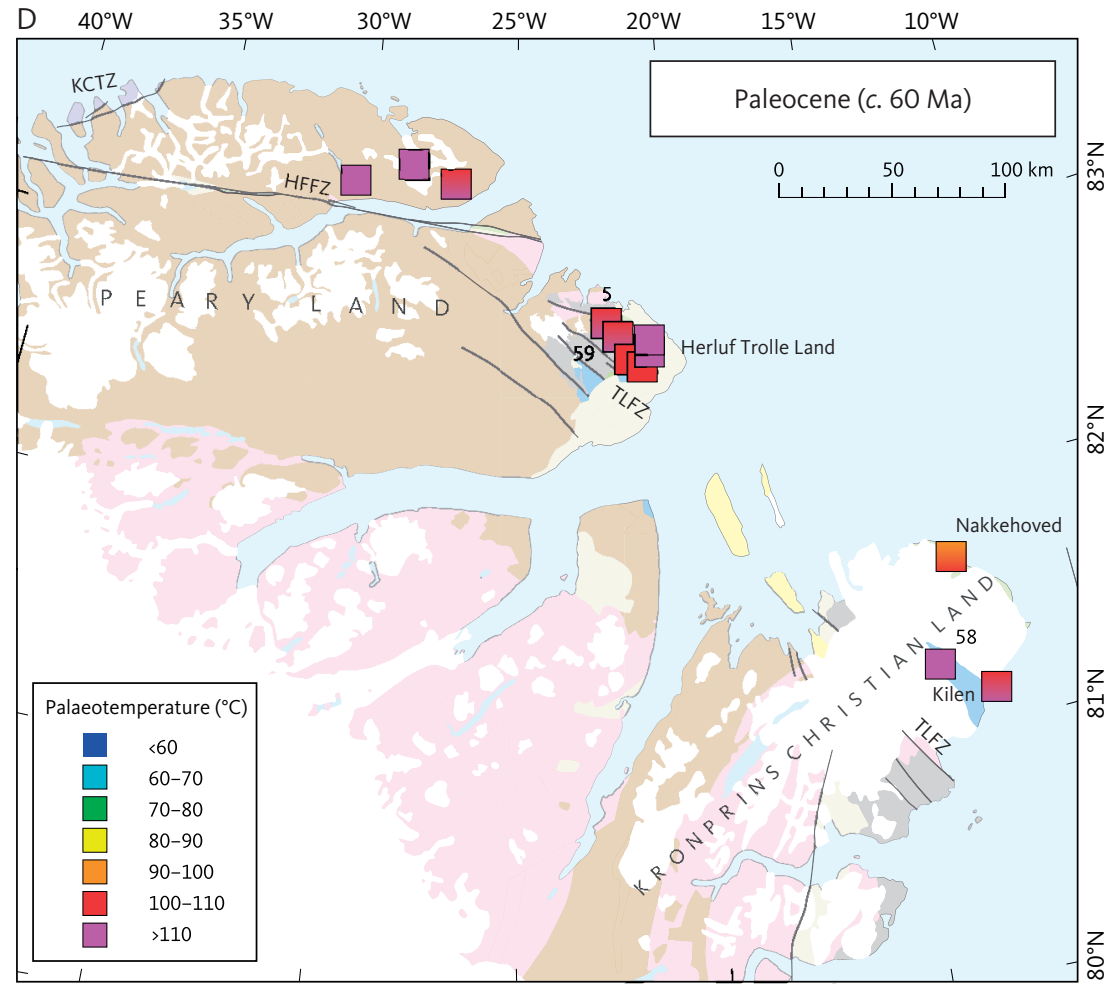

Quartz veins containing fluid inclusions with homogenisation temperatures of $197-236^{\circ} \mathrm{C}$ were formed during the thermal event, which was interpreted to have been short-lived and to have occurred at shallow burial depths (Håkansson et al. 1994). Samples of the Nakkehoved Formation showed diagenetic clay assemblages defining a low-grade greenschist metamorphic fabric, consistent with heating to palaeotemperatures of $200-300^{\circ} \mathrm{C}$ or above. Palynology studies also indicate a high degree of thermal alteration, consistent with such palaeotemperatures. Håkansson et al. (1994) found it unlikely that the thermal influence came from magmatic activity, in part due to the total absence of accessory minerals in the quartz veins. Paech \& Estrada 

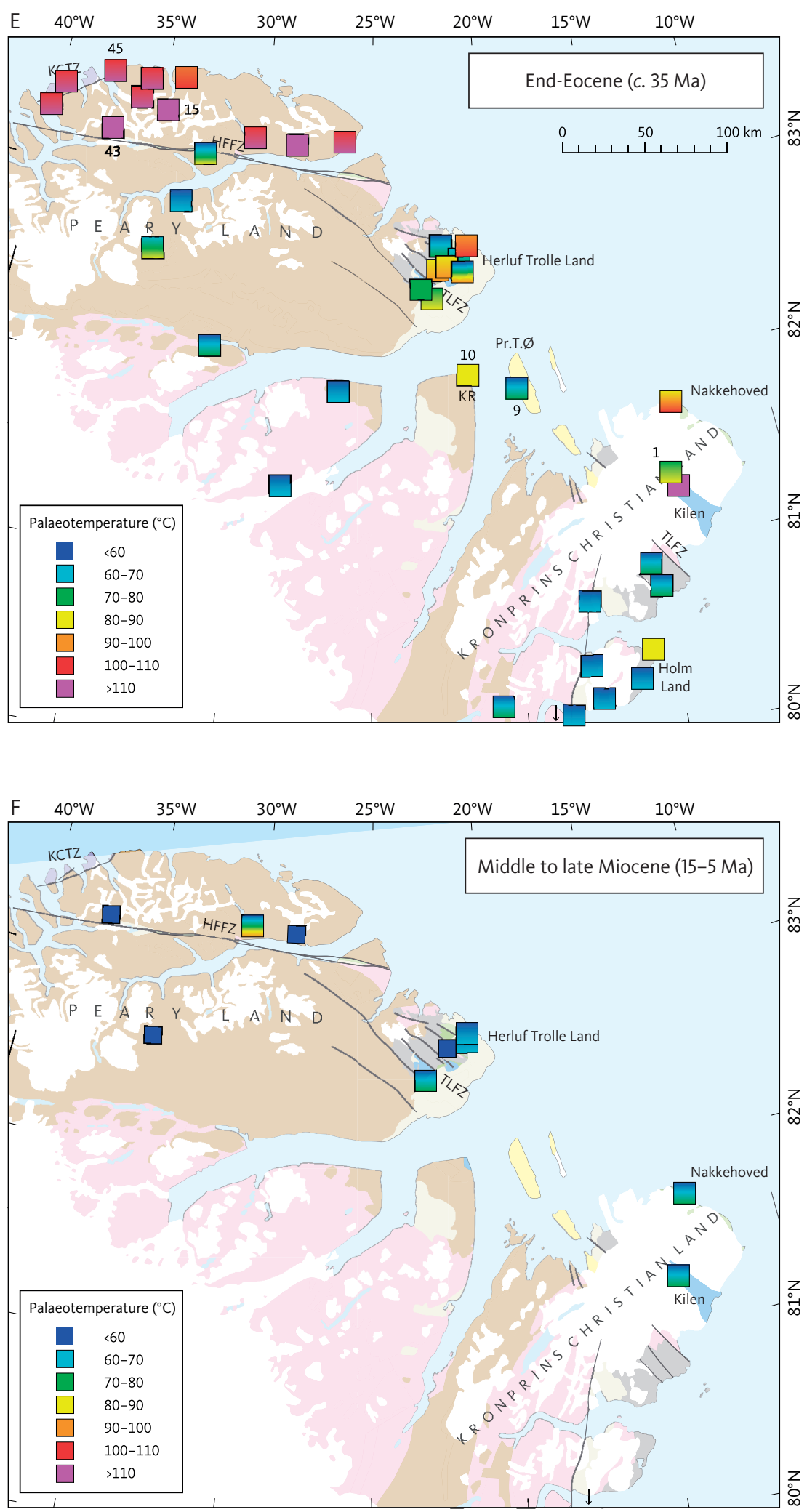

Fig. 11 (Continues) Palaeotemperatures derived from AFTA. A: Early Permian (295$290 \mathrm{Ma})$. B: Late Triassic (225-210 Ma). C: Late Jurassic (165-150 Ma). D: Paleocene (c. $60 \mathrm{Ma}$ ). E: End-Eocene (c. $35 \mathrm{Ma}$ ). F: Middle to late Miocene (15-5 Ma). Palaeotemperature for the mid-Cretaceous episode (115-90 Ma) is not shown as only one sample falls within the map frame. The small arrow in the lower right corner of $A, E$ and $\mathrm{F}$ indicates sample GC1113-48, which is located just south of the figure frame. Geology legend in Fig. 4. Numbers next to AFTA samples denote sample numbers. HFFZ: Harder Fjord Fault Zone. KCTZ: Kap Canon Thrust Zone. KR: Kap Rigsdagen. Pr.T.Ø: Prinsesse Thyra $\varnothing$. TLFZ: Trolle Land Fault Zone.
(2018) attributed the intense heat to the development of a plate boundary between north-eastern Greenland and Svalbard since the Oligocene. However, why that event should be localised to Nakkehoved is unclear. The profound changes in temperature over a short distance around Nakkehoved are unlikely to be due to differences in heat flow but are more likely to reflect localised heating or differential exhumation (for further discussion, see Section 4.3.1).

Håkansson et al. (1994) reported a VR value of c. $2 \%$ in a sample of the Thyra $\varnothing$ Formation from Prinsesse Margrethe $\varnothing$, which indicates intense heating of this sample after deposition, specifically in post-Paleocene times (Håkansson et al. 1994). This observation, together with 


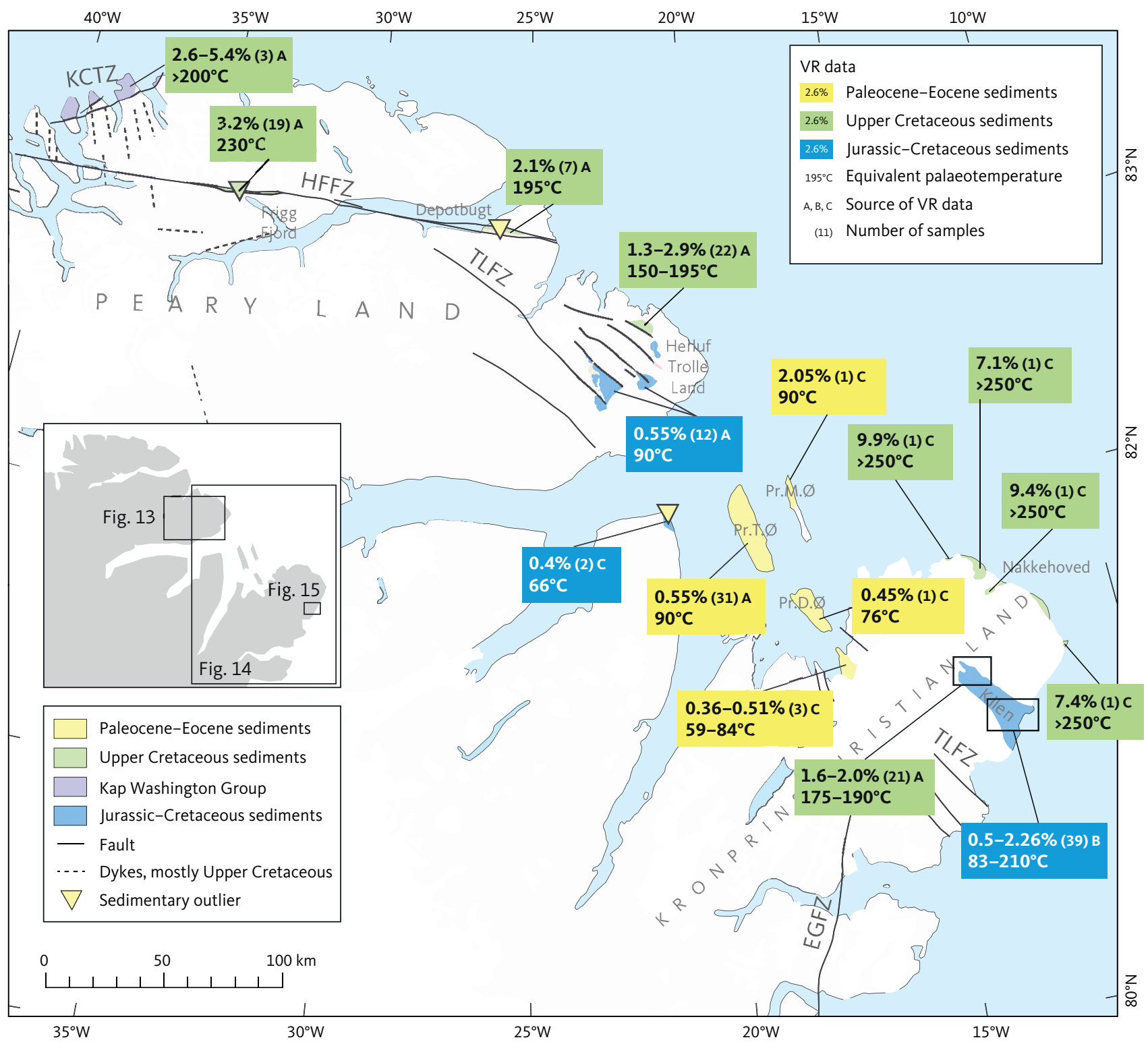

Fig. 12 Published vitrinite reflectance (VR) values from Mesozoic and Palaeogene units of the Wandel Sea Basin. Coloured boxes: VR values and corresponding maximum palaeotemperatures (Burnham \& Sweeny 1989). Source of VR data indicated by letters A: Paech \& Estrada (2018), B: Pedersen et al. (2018), C: Håkansson et al. (1994). When values are available from multiple sources, those from Paech \& Estrada (2018) are shown. Pr.D.Ø: Prinsesse Dagmar Ø. Pr.M.Ø: Prinsesse Margrethe $\emptyset$. Pr.T.Ø: Prinsesse Thyra $\emptyset$. Detail of Kilen in Fig. 15.

the extreme VR values of Upper Cretaceous sediments around Nakkehoved, led Håkansson \& Pedersen (1982, 2001) to argue for a short-lived 'post-Paleocene thermal event'. However, this VR value was based on only a small number of measurements and was considered to be unreliable (Paech \& Estrada 2018).

VR values between 0.5 and $1.19 \%$ reported by Pedersen et al. (2018), mainly from the southern part of Kilen, indicate maximum palaeotemperatures of $83-155^{\circ} \mathrm{C}$. Just one value lies outside this range $\left(2.57 \% ; 210^{\circ} \mathrm{C}\right)$ for Cretaceous formations that have been thrusted and folded in large open folds. These maturity data were interpreted in terms of large-scale folds with higher palaeotemperatures in anticlines, lower palaeotemperatures in synclines and an overall warming-northwards trend from the coastal zone of Kilen to inland areas (Pedersen et al. 2018). This suggests that the Mesozoic parts of the Wandel Sea Basin and Kilen represent Late Cretaceous rift basins that subsequently underwent north-south compression (Svennevig et al. 2016). Pedersen et al. (2018) modelled the pre-folding position of the strata and maturity data along a $9 \mathrm{~km}$ long river section, which cuts large-scale folds and thrusts in the southern part of Kilen. This was possible due to the moderate maturity along the section (VR between 0.5 and $1.2 \%$ ) and the consequent limited thermal alteration of, for example, dinocysts, which ensured a good biostratigraphic control. Structural restoration along the section revealed 
a deeper pre-deformation burial of the northern area, which Pedersen et al. (2018) interpreted as rift-related maximum burial after the Santonian, which is the age of the youngest sediments on Kilen (Hovikoski et al. 2018). The subsequent folding and thrusting that occurred during basin inversion were assumed by Pedersen et al. (2018) to be of the Paleocene-Eocene age.

\subsection{Comparison of AFTA and VR data}

In this study, we compare thermal history interpretations from AFTA and VR data in Mesozoic and Palaeogene units in the region from Herluf Trolle Land to Kronprins Christian Land (Figs. 12-15). This area is chosen because variation in VR levels across the region, combined with the thermal history solutions from AFTA, provides key insights into the mechanisms responsible for the observed maturity levels. Thermal history constraints for Cenozoic palaeothermal episodes derived from AFTA and VR data are shown in Figs. 13-15. These figures do not show the Mesozoic cooling events identified from AFTA, as the VR data are measured in units which post-date these events, and because the AFTA results show that three Cenozoic events dominate the thermal history of this region (Fig. 10).

\subsubsection{Northern Peary Land}

In northern Peary Land, a small number of samples close to the HFFZ cooled below c. $110^{\circ} \mathrm{C}$ in the Paleocene event (Fig. 12). However, most samples in this region cooled below $c .110^{\circ} \mathrm{C}$ in the end-Eocene event. Given that some samples appear to have cooled in both episodes, it seems likely that samples that cooled below $c$. $110^{\circ} \mathrm{C}$ at c. $35 \mathrm{Ma}$ also cooled at $60 \mathrm{Ma}$, but remained at, or were reheated to palaeotemperatures $>110^{\circ} \mathrm{C}$ until cooling that began at the end of the Eocene. It is possible that cooling from palaeotemperatures of c. $200^{\circ} \mathrm{C}$, represented by the higher VR values in the region between the KCFZ and HFFZ, may have begun prior to $60 \mathrm{Ma}$ in a separate event, which cannot be resolved from the AFTA data. However, the simplest interpretation is that cooling from C. $200^{\circ} \mathrm{C}$ in northern Peary Land began in the regional Paleocene episode at c. $60 \mathrm{Ma}$.

\subsubsection{Herluf Trolle Land}

The mean VR value of $0.55 \%$ from Paech \& Estrada (2018) in 12 Lower Cretaceous samples from southern Herluf Trolle Land indicates a maximum palaeotemperature of C. $90^{\circ} \mathrm{C}$ (Fig. 13). Paech \& Estrada (2018) considered this level of maturity to be the regional 'background' level away from major fault systems and interpreted it to reflect the earlier presence of a considerable overburden across the region. AFTA data in samples GC1113-63 and -64 , from this area (south-west of fault F in Fig. 13), reveal end-Eocene palaeotemperatures of $75-90^{\circ} \mathrm{C}$ and $70-80^{\circ} \mathrm{C}$, respectively, from which cooling began at c. $35 \mathrm{Ma}$. Samples GC1113-21 and -22, also south of fault $F$, define similar end-Eocene palaeotemperatures. These end-Eocene palaeotemperatures from AFTA are broadly consistent with the maximum palaeotemperatures around $90^{\circ} \mathrm{C}$, indicated by the VR data in nearby Upper Jurassic - Lower Cretaceous units (Paech \& Estrada 2018). This consistency suggests that VR values reflect maximum paleotemperatures in the end-Eocene episode. We, therefore, interpret maximum palaeotemperatures of $75-90^{\circ} \mathrm{C}$, as defined from AFTA and VR in this region, to primarily reflect deeper burial prior to exhumation, which began at the end of the Eocene. These values are relatively uniform over a wide area.

In contrast, VR values up to $3 \%$ in the Upper Cretaceous Herlufsholm Strand Formation from northern Herluf Trolle Land indicate maximum palaeotemperatures at around $150-200^{\circ} \mathrm{C}$ within the prominent fault zone (Fig. 13). AFTA data from this region provide consistent evidence of palaeotemperatures $>100^{\circ} \mathrm{C}$ from which cooling began in the Paleocene at c. $60 \mathrm{Ma}$ (GC1113-15, $-59,-67$ and -68). As all tracks were totally annealed prior to cooling that began at c. $60 \mathrm{Ma}$, AFTA data in these samples define only lower limits to the maximum palaeotemperature, and direct comparison with the VR data is not possible. The most straightforward interpretation is that cooling from a palaeotemperature of c. $200^{\circ} \mathrm{C}$, as indicated by the VR data, began at c. 60 Ma. Furthermore, mid-Paleocene palaeotemperatures are strongly controlled by the faults of the TLFZ (Fig. 13; Paech \& Estrada 2018). Samples to the north-east of fault $F$ cooled at $c$. 60 Ma (GC1113-15, -23, -59, -67,-68), whereas samples to the south-west of that fault do not show any evidence of this event (GC1113-21, -22, -63, -64). AFTA data from the five samples north-east of fault $F$ also show evidence of cooling beginning at $35 \mathrm{Ma}$ from palaeotemperatures of c. $80-90^{\circ} \mathrm{C}$, similar to those defined from AFTA in the four southern samples, and thus, providing further evidence that this episode represents relatively uniform regional exhumation.

\subsubsection{East of Herluf Trolle Land}

The mean VR value of $0.55 \%$ in 31 Palaeogene samples from Prinsesse Thyra $\varnothing$ corresponds to a palaeotemperature of C. $90^{\circ} \mathrm{C}$ (Fig. 14). VR data in three samples of Palaeogene age from Prinsesse Ingeborg Halvø on Kronprins Christian Land, as well as a Lower Cretaceous sample from Kap Rigsdagen, define maximum palaeotemperatures of $66-90^{\circ} \mathrm{C}$. These are consistent with maximum post-depositional palaeotemperatures of $20-75^{\circ} \mathrm{C}$ and $80-90^{\circ} \mathrm{C}$ derived from AFTA data in samples GC1113-9 and -10, respectively. These palaeotemperatures are again attributed to the end-Eocene palaeothermal episode and are consistent with the 
values from Herluf Trolle Land that are also attributed to deeper burial prior to regional exhumation, which began at c. $35 \mathrm{Ma}$.

Along the north coast of Kronprins Christian Land and in parts of Kilen, VR reaches very high values in samples of Cretaceous age:

1. Around Nakkehoved, VR values for Upper Cretaceous units of $7-10 \%$ indicate maximum palaeotemperatures in excess of $250^{\circ} \mathrm{C}$ (Fig. 14). AFTA data in sample GC1113-55, also from Nakkehoved, indicate that cooling from $>125^{\circ} \mathrm{C}$ began between 101 and $48 \mathrm{Ma}$. The simplest interpretation is that these values represent the Paleocene (c. $60 \mathrm{Ma}$ ) palaeothermal episode.

2. In 21 samples from inland Kilen, VR values are in the range of $1.6-2 \%$ (equivalent to $C .174^{\circ} \mathrm{C}$ and $200^{\circ} \mathrm{C}$, respectively; Fig. 15). AFTA data in sample GC1113-58 from this area also define cooling from $>120^{\circ} \mathrm{C}$, which began between 60 and 45 $\mathrm{Ma}$, supporting that these elevated maturity levels reflect the palaeothermal episode at $60 \mathrm{Ma}$. However, AFTA data in nearby sample GC1113-1 define cooling from $>130^{\circ} \mathrm{C}$ between 45 and 25 $\mathrm{Ma}$, which we attribute to the cooling episode that began at the end of the Eocene. It could be that this sample initially underwent Paleocene cooling from a higher palaeothermal maximum, and then remained at $>130^{\circ} \mathrm{C}$ until further cooling in the end- Eocene episode. In any event, the more recent episode was clearly more pronounced in sample GC1113-1 compared with sample GC111358. The higher end-Eocene palaeotemperature

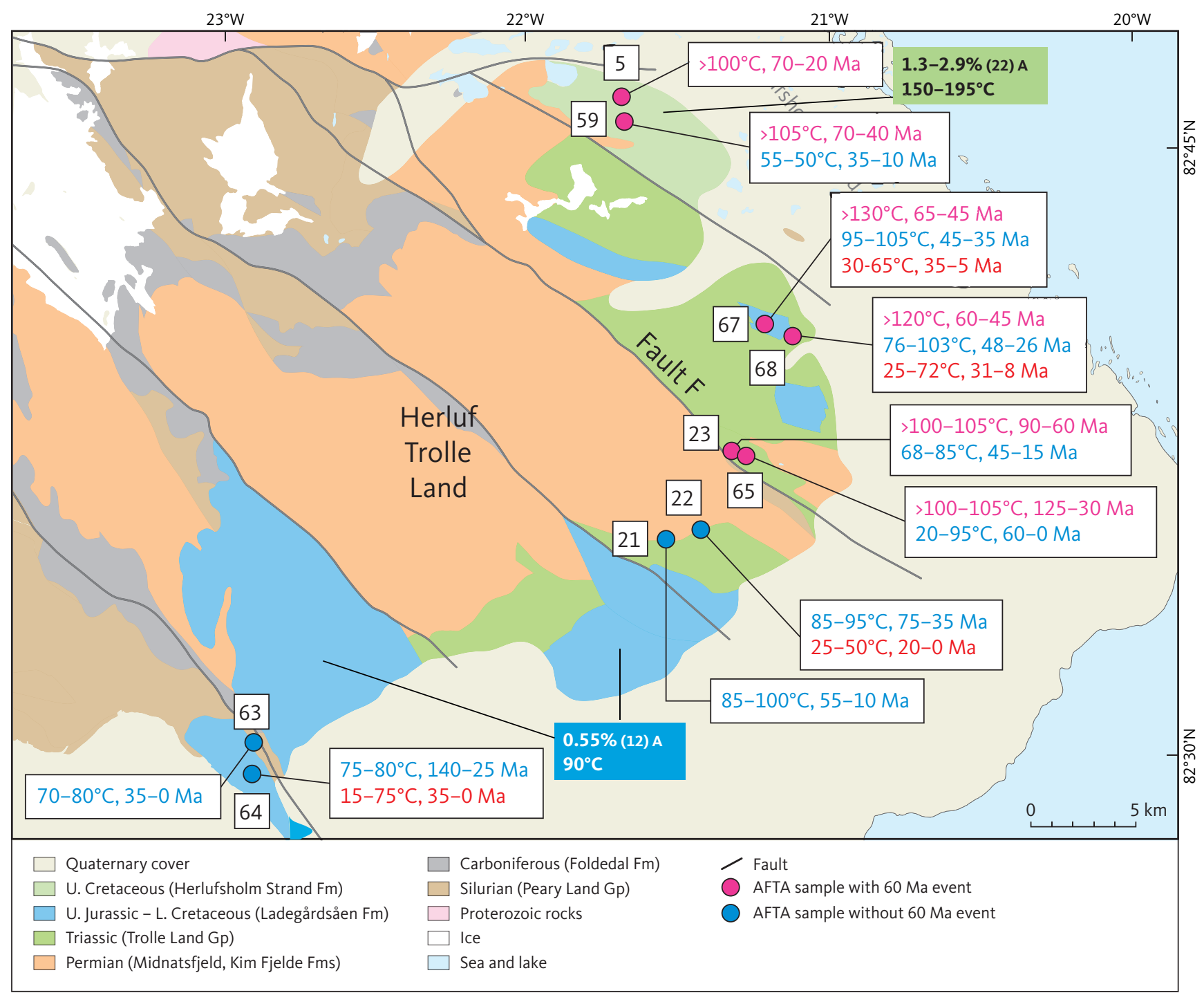

Fig. 13 Cenozoic palaeothermal constraints for Herluf Trolle Land. Heating during the Paleocene event (c. $60 \mathrm{Ma}$ ) is controlled by the numerous faults belonging to the Trolle Land Fault Zone, as suggested by Paech \& Estrada (2018). Only samples north-east of 'Fault

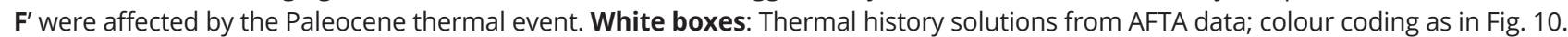
Coloured boxes: VR values and corresponding maximum palaeotemperatures from adjacent samples; see Fig. 12. Source of VR data indicated by letter A: Paech \& Estrada (2018). Map location indicated in Fig. 12. Basemap modified from Bjerager et al. (2019). 


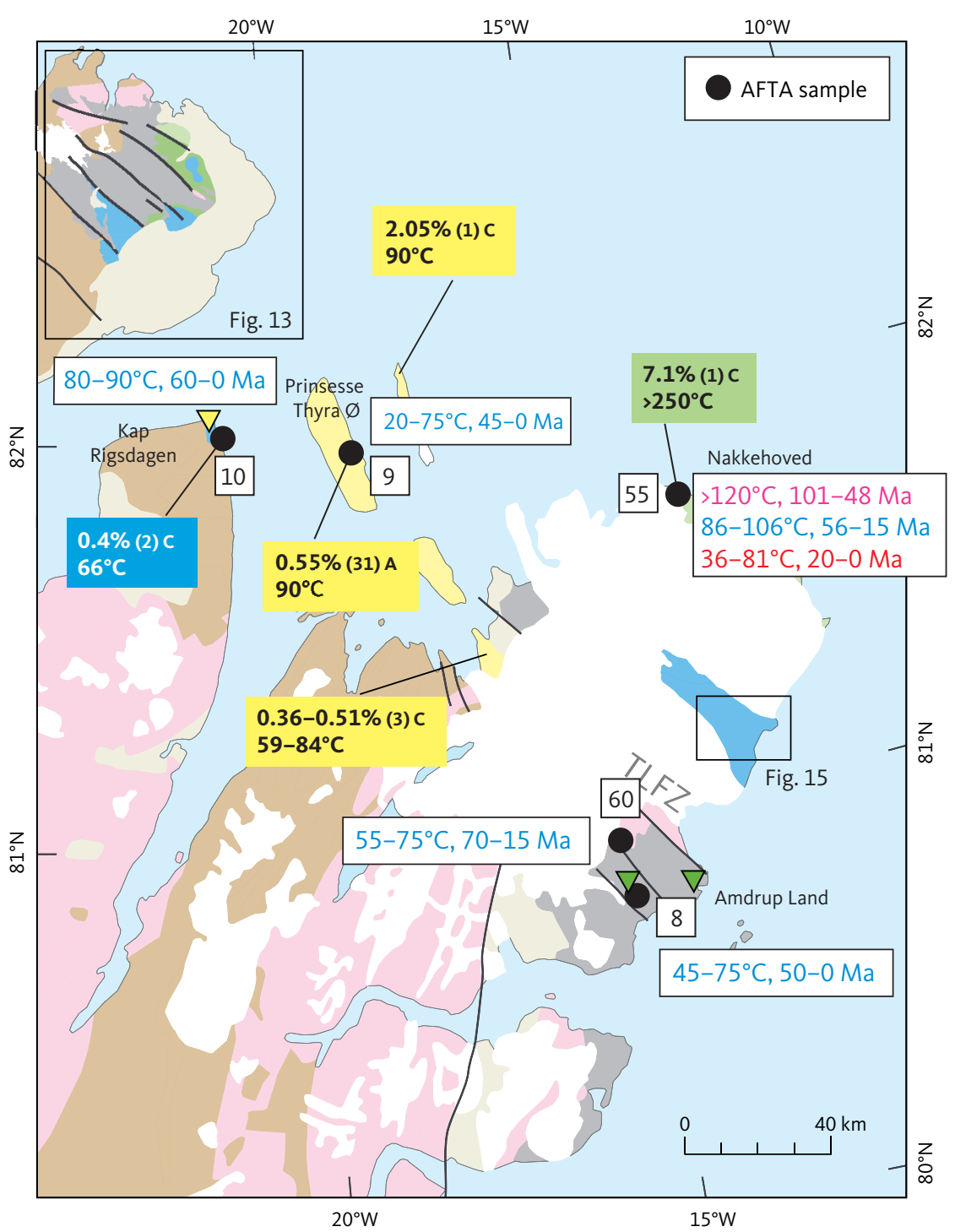

Fig. 14 Cenozoic palaeothermal constraints east of Herluf Trolle Land. White boxes: thermal history solutions from AFTA, colour coding as in Fig. 10. Coloured boxes: VR values and corresponding maximum palaeotemperatures from adjacent samples, colour coding as in Fig. 12. Source of VR data indicated by letters $\mathbf{A}$ : Paech \& Estrada (2018), C: Håkansson et al. (1994). Solid black lines: faults. Map location indicated in Fig. 12. Detail of Kilen in Fig. 15. Key to bedrock geology and other abbreviations in Fig. 4. in sample GC11113-1 emphasises the complex nature of the underlying thermal history and highlights the need for further studies in this region.

3. In more coastal areas of Kilen, VR values for the Cretaceous sediments are high and quite variable across the region (most values between 0.5 and $1.19 \%$, equivalent to $83-155^{\circ} \mathrm{C}$; Fig. 15). The variation in VR values was attributed to differing amounts of burial prior to exhumation due to basin inversion of 'presumed Paleocene-Eocene age' (Pedersen et al. 2018). The only direct comparison between AFTA and VR data in this region is sample GC1113-25, which cooled from $>100^{\circ} \mathrm{C}$ between 65 and $10 \mathrm{Ma}$. We attribute this to the Paleocene palaeothermal episode from which cooling began at c. $60 \mathrm{Ma}$. This is again consistent with the timing of cooling from extreme palaeotemperatures, which is indicated by the elevated VR levels further north in Nakkehoved. Given the considerable variation in VR values along the western margin of Kilen and the lack of AFTA data from this region, it is not possible to draw any conclusions regarding the timing of cooling there.

AFTA data in samples GC1113-8 and -60, from Amdrup Land, south of Kilen, define maximum post-Jurassic palaeotemperatures of $c .55-75^{\circ} \mathrm{C}$ (Fig. 14), which is attributed to the end-Eocene (c. $35 \mathrm{Ma}$ ) episode. These palaeotemperatures are similar to those derived from AFTA and VR data obtained from areas to the north away from areas of significant deformation - and provide further evidence of relatively uniform deeper burial across the region prior to the onset of exhumation at the Eocene-Oligocene boundary.

\subsection{Synthesis}

Elevated VR values (1.5-3\%; equivalent to $150-225^{\circ} \mathrm{C}$ ) in Mesozoic units within the major fault zones from northern Peary Land to Kronprins Christian Land represent a mid-Paleocene palaeothermal maximum from which 


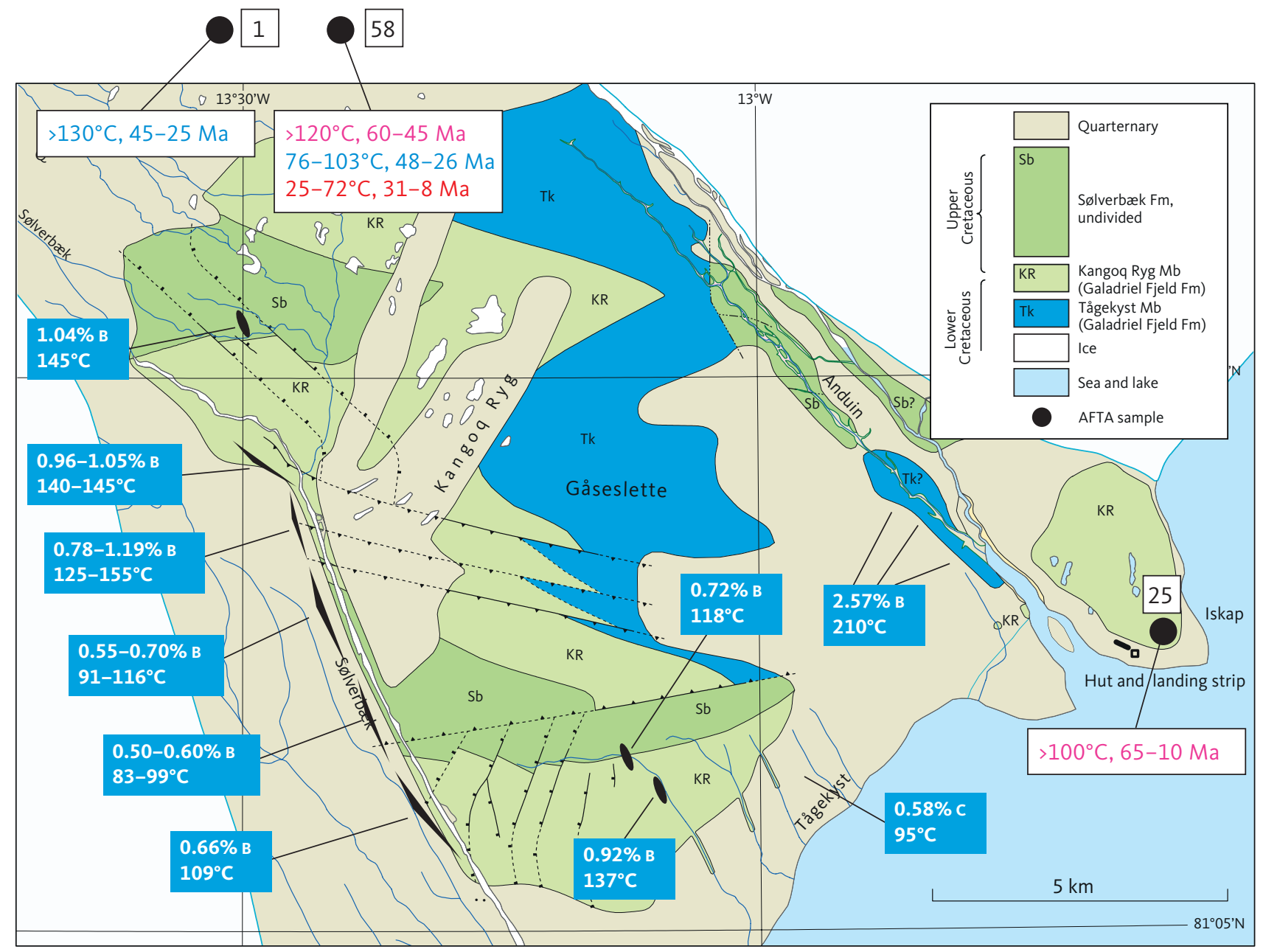

Fig. 15 Palaeothermal constraints for south-east Kilen. The palaeotemperature constraints from VR are consistent with those from AFTA, but the timing constraints on the onset of cooling vary. White boxes: thermal history solutions from AFTA, colour coding as in Fig. 10. Numbers next to AFTA samples denote sample numbers. Blue boxes: VR values and associated maximum palaeotemperatures for Cretaceous sediments. Source of VR data indicated by letters B: Pedersen et al. (2018) and C: Håkansson et al. (1994). Map location in Fig. 14. Base map modified from Hovikoski et al. (2018, Fig. 4) where further details of the map are explained.

cooling began at c. $60 \mathrm{Ma}$. In contrast, lower VR values (c. $0.55 \%$, equivalent to c. $90^{\circ} \mathrm{C}$ ), in Mesozoic and Palaeogene units located away from zones of major deformation, represent the end-Eocene palaeothermal episode from which cooling began at c. 35 Ma. AFTA data from the zones of deformation also show evidence of cooling, which began at this time from palaeotemperatures of c. $80-90^{\circ} \mathrm{C}$, thus, emphasising the regional nature of this episode, although end-Eocene palaeotemperatures were higher in Peary Land north of the HFFZ (see Section 5.2.2).

A major exception to this regional pattern occurs on the north coast of Kronprins Christian Land around Nakkehoved. Extremely high VR values between 7 and $10 \%$ in samples of Upper Cretaceous sediments indicate maximum palaeotemperatures greater than $250^{\circ} \mathrm{C}$. AFTA data in the only sample from this region indicate that cooling from $>125^{\circ} \mathrm{C}$ began in the Paleocene or possibly earlier, since results provide only minimum palaeotemperature estimates. This event may, therefore, have been synchronous with Paleocene cooling in the fault zones, or may have been earlier and, as the event affected Upper Cretaceous sediments, it must have happened in Late Cretaceous or Paleocene times.

AFTA data in sample GC1113-1 from Kilen define cooling from $>130^{\circ} \mathrm{C}$ during the end-Eocene cooling episode, suggesting some variation in the magnitude of this episode. The VR value of $c .2 \%$ in a sample of Palaeogene age on Prinsesse Margrethe $\varnothing$ may also reflect the higher end-Eocene palaeotemperature in sample GC1113-1 (note the earlier comments regarding the uncertainty associated with this VR value).

We suggest that exhumation that began in the mid-Paleocene represents the inversion of the fault zones, while exhumation that began at the end of the Eocene was regional and primarily represents burial followed by uplift and erosion However, there is also evidence of end-Eocene palaeotemperatures that were 
higher than the regional, uniform magnitude, for example, sample GC1113-1 from Kilen and the possibly highly mature Thyra $\varnothing$ Formation on Prinsesse Margrethe $\varnothing$. The extreme palaeotemperatures focussed along the north coast of Kronprins Christian Land were likely reached during the Late Cretaceous or Paleocene times.

\section{Geological controls on the cooling episodes identified from AFTA}

In this section, we compare AFTA and VR results with evidence from the stratigraphic record to investigate the geological processes responsible for the cooling episodes identified in the Wandel Sea Basin (Fig. 16). We also compare these cooling episodes with studies from central West Greenland and North-East Greenland (Fig. 17; Japsen et al. 2006, in press) and illustrate the heating and cooling (burial and exhumation) history, with examples based on samples that provide stratigraphic constraints on the age of removed sections (Fig. 18).

\subsection{Palaeozoic-Mesozoic cooling events 5.1.1 Early Permian episode}

The early Permian cooling episode (beginning between 295 and $290 \mathrm{Ma}$ ) recognised from AFTA data in samples across the study area corresponds to the base-Permian hiatus identified across the basin between the middleupper Permian Kim Fjelde Formation and the upper Carboniferous Foldedal Formation (Fig. 16; Stemmerik et al. 1998). We, therefore, interpret early Permian cooling as reflecting a major phase of exhumation, following deeper burial. For example, sample GC1113-63, a Silurian sandstone from Herluf Trolle Land, cooled from an early Permian palaeotemperature of c. $100^{\circ} \mathrm{C}$, corresponding to burial below a cover of Silurian to Carboniferous rocks with a thickness of $2.7 \mathrm{~km}\left(30^{\circ} \mathrm{C} / \mathrm{km}, 20^{\circ} \mathrm{C}\right.$ at the surface). The timing of this cooling episode is close to that of the late Carboniferous episode identified in North-East Greenland (beginning between 320 and 300 $\mathrm{Ma})$, which also correlates with a regional latest Carboniferous to mid-Permian unconformity (Surlyk 1990). It is, therefore, possible that these episodes reflect the same tectonic event (Fig. 17). It is not possible to define any pre-Permian cooling from the AFTA data, and therefore, it is not possible to use AFTA data to discriminate the thermal histories for upper and lower Carboniferous strata on Holm Land based on maturity data, as in Stemmerik et al. (1998).

\subsubsection{Late Triassic episode}

The Late Triassic cooling episode (beginning between 225 and $210 \mathrm{Ma}$ ) is identified from AFTA data away from the northern coastal regions. The onset of cooling in this episode could correspond to the older hiatus between the Upper Triassic Sortekløft Formation and the Middle Triassic Dunken Formation, identified on Herluf Trolle Land by Bjerager et al. (2019; Fig. 16). In Kilen, the episode corresponds to the inferred hiatus between the Middle Jurassic Mågensfjeld Formation and the Middle Triassic Isrand Formation (Alsen et al. 2017; Hovikoski et al. 2018; Svennevig et al. 2018). Sample GC111318 of upper Carboniferous Kap Jungersen Formation exposed on Holm Land reached a palaeotemperature above $100^{\circ} \mathrm{C}$ prior to Late Triassic cooling (Fig. 18A). This palaeotemperature corresponds to burial below a cover of Carboniferous to Triassic sediments, with a thickness exceeding $2.7 \mathrm{~km}\left(30^{\circ} \mathrm{C} / \mathrm{km}, 20^{\circ} \mathrm{C}\right.$ at the surface). The Late Triassic episode in the Wandel Sea Basin coincides with the Late Triassic episode in West Greenland, but slightly post-dates a Middle Triassic episode of cooling and exhumation in North-East Greenland (Fig. 17), suggesting a possible lag between events in the two areas.

\subsubsection{Late Jurassic episode}

The Late Jurassic cooling episode (beginning between 165 and $150 \mathrm{Ma}$ ) is recognised in samples away from the northern coasts and in one sample from Herluf Trolle Land. The onset of cooling in this episode corresponds to the hiatus between the Upper Jurassic - Lower Cretaceous Ladegårdsåen Formation and the Upper Triassic Sortekløft Formation on Herluf Trolle Land (Håkansson \& Pedersen 2015; Bjerager et al. 2019; Fig. 16). We interpret this cooling episode as exhumation following deeper burial. According to Håkansson \& Pedersen (2015), the base of Ladegårdsåen Formation is middle Oxfordian in age (c. $160 \mathrm{Ma}$ ), which constrains the onset of Late Jurassic cooling to between 165 and 160 $\mathrm{Ma}$, at the Middle-Late Jurassic transition (CallovianOxfordian). This agrees well with the Callovian-Oxfordian hiatus between the Birkelund Fjeld and Mågensfjeld Formations observed in Kilen (Hovikoski et al. 2018).

The temporal overlap between the Late Jurassic episode and the Callovian-Oxfordian hiatus across most of the basin indicates that the cooling episodes involved exhumation. For example, sample GC1113-22 from Herluf Trolle Land of Lower Triassic sandstone reached a palaeotemperature above $115^{\circ} \mathrm{C}$ prior to Late Jurassic cooling (Fig. 18B). This corresponds to burial below a cover of Triassic to Middle Jurassic sediments, with a thickness exceeding $3 \mathrm{~km}\left(30^{\circ} \mathrm{C} / \mathrm{km}, 20^{\circ} \mathrm{C}\right.$ at the surface). The Late Jurassic episode that affected the Wandel Sea Basin coincides with the Late Jurassic episode that affected West Greenland, but it began after the Early Jurassic episode of cooling and exhumation in North-East Greenland (Fig. 17). As this delay of about 20 Myr is consistent with the delay of the Triassic episode in North-East Greenland compared with western and northern Greenland, it seems likely to represent 


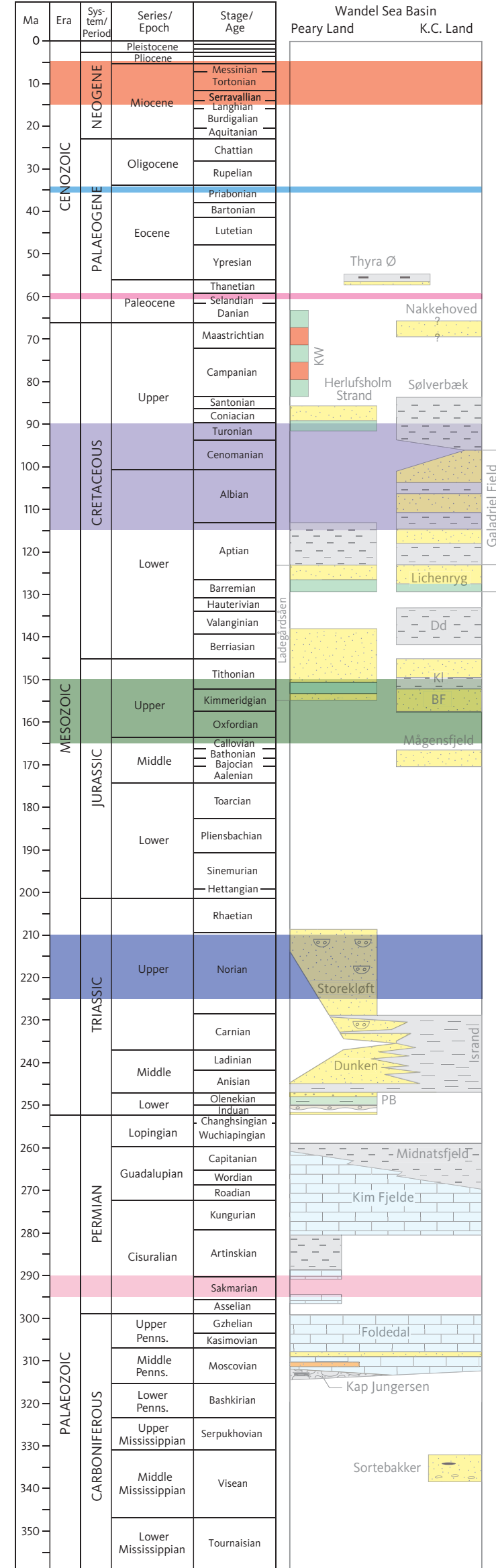

Legend

Sedimentary environments

$\square$ Fluvial, lacustrine

Marine sandstone

Marine carbonate

Marine mudstone

Evaporites

Extrusive igneous rocks

Volcanics, volcanoclastics

Lithological symbols

Bod conglomerate

$\because \therefore$ Sandstone

$\underline{\overline{-} \div \bar{*}}$ Siltstone

$\left[\begin{array}{ll}- & - \\ - & -\end{array}\right.$ Mudstone/shale

$\rightarrow \begin{aligned} & \text { Organic rich } \\ & \text { mudstone/shale }\end{aligned}$

Limestone

- $\quad$ Coal layers

$\nabla$ Channel fills

Horizontal shading

Time interval during which cooling began
Fig. 16 Comparison between the regional cooling episodes identified from AFTA (Table 4) and the stratigraphic scheme for the Wandel Sea Basin (Fig. 5). The thickness of the horizontal, coloured bars indicates the interval during which the cooling began in each episode.

a protracted tectonic development between the two areas.

\subsubsection{Mid-Cretaceous episode}

The mid-Cretaceous cooling episode (beginning between 115 and $90 \mathrm{Ma}$ ) is identified in only one sample within the Wandel Sea Basin. The episode corresponds to an Aptian to Turonian hiatus on Herluf Trolle Land between the Upper Cretaceous (Turonian-Coniacian) Herlufsholm Strand Formation and the Upper Jurassic - Lower Cretaceous (Oxfordian-Barremian) Ladegårdsåen Formation (Fig. 16) (Håkansson \& Pedersen 2015; Piasecki et al. 2018). In Kilen, Hovikoski et al. (2018) marked a possible late Albian to Cenomanian hiatus between the Galadriel Fjeld and Sølverbæk formations in the Kilen Fjelde area. The temporal overlap between this hiatus and the mid-Cretaceous cooling episode suggests that cooling involved exhumation following deeper burial.

The mid-Cretaceous episode of uplift and erosion postdates the Barremian unconformity (c. $135 \mathrm{Ma}$ ), which resulted from HALIP-related regional uplift and is recorded by stratigraphic and palaeo-environmental changes on Peary Land and on Kilen (Ineson et al. 2020). It is possible that the effects of the Barremian episode overlaps with those of the mid-Cretaceous event as the 

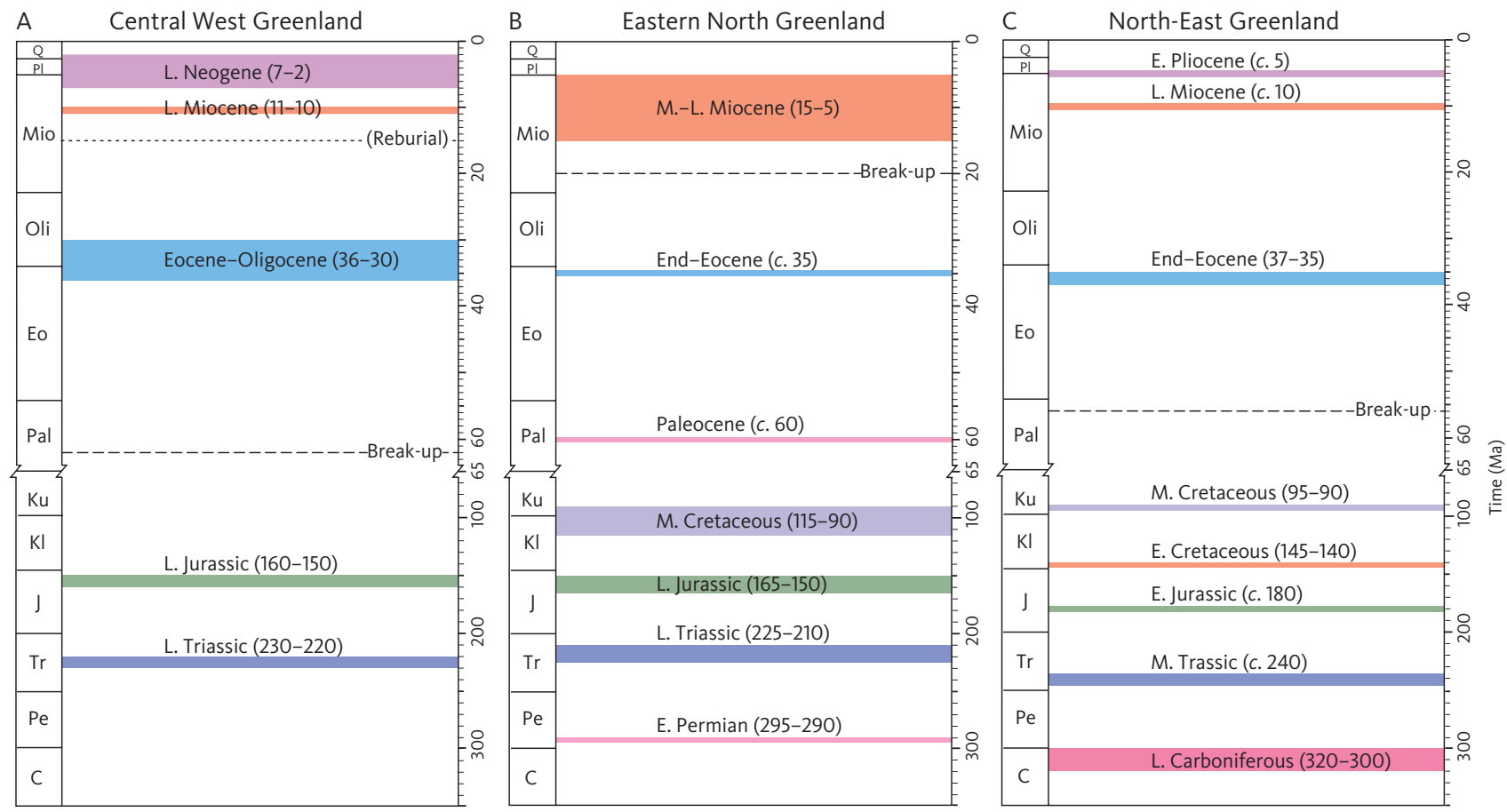

- Time interval during which cooling began

(7-2) Onset of cooling (Ma) from AFTA

Fig. 17 Timing of regional, post-Devonian episodes of uplift and erosion in three regions of Greenland estimated from AFTA. A: Central West Greenland (Japsen et al. 2006, 2009). B: Eastern North Greenland (Table 4; this study). C: North-East Greenland (Japsen et al. in press). Break-up west of Greenland took place in mid-Paleocene (c. $62 \mathrm{Ma})$, but sea-floor spreading ceased there by the end of the Eocene. In contrast, the opening of the North-East Atlantic, east of Greenland, began at the Paleocene-Eocene transition (c. $56 \mathrm{Ma}$ ) and is still ongoing (Chalmers \& Pulvertaft 2001; Oakey \& Chalmers 2012; Gaina et al. 2017). The Fram Strait between Greenland and Svalbard opened in early Miocene (c. 20 Ma; Jokat et al. 2016). L: Late. E: Early. M: Middle. C: Carboniferous. Pe: Permian. Tr: Triassic. J: Jurassic. KI: Lower Cretaceous. Ku: Upper Cretaceous. Pal: Paleocene. Eo: Eocene. Oli: Oligocene. Mio: Miocene. PI: Pliocene. Q: Quaternary.

one sample within the Wandel Sea Basin, which has been assigned to the latter event cooled between 155 and $50 \mathrm{Ma}$.

The onset of cooling in this episode coincides with a mid-Cretaceous episode in North-East Greenland (Fig. 17), which represents an episode of regional exhumation (Japsen et al. in press). We, therefore, suggest that both areas were affected by exhumation at 95-90 Ma.

\subsection{Cenozoic cooling episodes \\ 5.2.1 Mid-Paleocene episode}

The mid-Paleocene cooling episode (beginning c. 60 $\mathrm{Ma}$ ) recorded in samples from coastal and near-coastal locations corresponds to the hiatus between the upper Paleocene - lower Eocene Thyra $\varnothing$ Formation and Upper Cretaceous strata (e.g. Santonian Sølverbæk Formation in Kilen; Fig. 16). The study results from the HFFZ and the TLFZ reveal Paleocene cooling from $>110^{\circ} \mathrm{C}$, which began at c. $60 \mathrm{Ma}$. We interpret this cooling in terms of exhumation following deeper burial (Fig. 11D). This event is also inferred to have affected northern Peary Land in the region between the KCTZ and HFFZ where high end-Eocene palaeotemperatures dominate.

As discussed in Section 4.3.3, AFTA and VR data from Kilen and northern Herluf Trolle Land indicate that cooling from a maximum post-depositional palaeotemperature of up to $200^{\circ} \mathrm{C}$ within major fault zones also began during the Paleocene (c. $60 \mathrm{Ma}$ ) palaeothermal episode. The results of this study support the interpretation of Pedersen et al. (2018), according to which the high maturity of sediments in the southern part of Kilen was reached during the maximum burial prior to post-Coniacian basin inversion in response to a strong compressional event. For example, sample GC1113-58 of Lower Cretaceous Lichenryg Formation exposed in Kilen reached a palaeotemperature of $>120^{\circ} \mathrm{C}$ prior to Paleocene cooling (Fig. 18C). This corresponds to burial beneath more than $3.3 \mathrm{~km}$ of Cretaceous to Paleocene sediments. Deep burial of the Cretaceous sediments in Kilen is in good agreement with the occurrence of well-developed stylolites in the lower part of Lichenryg Formation in the northern part of Kilen (around Dromledomen; C. Heinberg \& H. Dypvik, personal communication 2019). Similar considerations apply to 
samples GC1113-5 and -59 of the Upper Cretaceous Herlufsholm Strand Formation (Herluf Trolle Land) that reached palaeotemperatures $>100^{\circ} \mathrm{C}$ prior to Paleocene cooling.

In summary, we observe a spatial and temporal overlap between the inversion of the major fault zones of the Wandel Sea Basin and the onset of cooling and exhumation that began at c. $60 \mathrm{Ma}$. We infer that the compression that resulted in inversion of the fault zones began in the mid-Paleocene (i.e. the Kronprins Christian Land Orogeny; Håkansson \& Pedersen 1982; Svennevig et al. 2016). This timing is consistent with the late Paleocene age of the lower part of the Thyra $\varnothing$ Formation, which may represent erosional products derived from the inversion of the fault zones. This interpretation is supported by the abundant of reworked Cretaceous dinoflagellate cysts and palynomorphs in these deposits (Lyck \& Stemmerik 2000; Piasecki et al. 2018).

A corresponding episode is not revealed by AFTA data from North-East Greenland or West Greenland (Fig. 17). However, the timing of this episode overlaps with that of a Late Cretaceous - early Cenozoic episode (beginning between 70 and $50 \mathrm{Ma}$ ), which affected the southernmost tip of East Greenland $\left(63^{\circ}-61^{\circ} \mathrm{N}\right.$; Green et al. 2014). Dam et al. (1998) reported geological evidence for rapid uplift and fluvial erosion in the mid-Paleocene followed by subsidence contemporaneous with the first volcanic extrusions in both West and East Greenland, and argued that the arrival of the Iceland plume controlled these transient, vertical movements.

\subsubsection{End-Eocene episode}

The cooling episode that began at the end of the Eocene (c. $35 \mathrm{Ma}$ ) is recognised in AFTA data in samples across almost the entire study area. The cooling episode affected the Wandel Sea Basin after the deposition of the Thyra $\varnothing$ Formation and coincides with periods of exhumation in North-East Greenland, as well as West Greenland (Fig. 17).

AFTA and VR data define fairly uniform palaeotemperatures of around $80-90^{\circ} \mathrm{C}$ away from major fault zones, corresponding to the regional (or background) level of maturity across the region. This is interpreted to represent primarily deeper burial prior to regional, relatively uniform exhumation that began at the end of the Eocene. The Palaeogene sediments on Prinsesse Thyra $\varnothing$ (e.g. GC1113-9) also reached such palaeotemperatures prior to the end-Eocene episode, implying that the heating there reflects burial below a late Paleocene to Eocene cover.

Piasecki et al. (2018) showed that the top $5 \mathrm{~m}$ of the section exposed at Kap Rigsdagen are of early-mid Eocene age and are part of the Thyra $\varnothing$ Formation. The
end-Eocene palaeotemperatures $\left(80-90^{\circ} \mathrm{C}\right)$ for sample GC1113-10 from Lower Cretaceous sediments overlain by Palaeogene sediments at Kap Rigsdagen must, therefore, reflect burial below a cover of Eocene sediments of similar thickness to that across Prinsesse Thyra $\varnothing$ (Fig. 18D). Assuming a palaeogeothermal gradient of $30^{\circ} \mathrm{C} / \mathrm{km}$ and a palaeosurface temperature of $10^{\circ} \mathrm{C}$, this range of palaeotemperatures corresponds to burial below 2.3-2.7 km of Eocene sediments. The choice of palaeosurface temperature used here reflects the warm temperate climate that Boyd (1990) estimated based on the Palaeogene flora preserved in the deposits on Prinsesse Thyra $\varnothing$. It is thus likely that about $2.5 \mathrm{~km}$ of upper Paleocene to Eocene sediments (including the Thyra Ø Formation) covered wide areas across the Wandel Sea Basin prior to the exhumation that began at the end of the Eocene. This suggests that large parts of the basin subsided during the Eocene.

Some samples from north of the HFFZ (e.g. GC1113-15, $-43,-45)$ cooled from much higher palaeotemperatures $\left(>110^{\circ} \mathrm{C}\right)$ compared with the majority of samples across the region (see Section 6.3). AFTA data for sample GC1113-1 from the northern part of Kilen also indicate cooling from $>130^{\circ} \mathrm{C}$ between 45 and 25 Ma during the end-Eocene episode.

\subsubsection{Mid-late Miocene episode}

The mid-late Miocene cooling episode (beginning between 15 and $5 \mathrm{Ma}$ ) is identified in the AFTA data from samples in coastal and near-coastal locations, and does not correlate with any known strata within the Wandel Sea Basin. It does, however, correlate with the late Miocene and early Pliocene events of uplift and incision that led to the formation of the present-day landscape in both West and North-East Greenland (Fig. 17; Japsen et al. 2006, in press). As the palaeotemperatures defined for this episode are moderate $\left(\right.$ c. $50-60^{\circ} \mathrm{C}$ at sea level), they are unlikely to be related to the early Pliocene cooling observed in North-East Greenland (Japsen et al. in press). We thus suggest that the mid-late Miocene episode identified in this study shares a common origin with the late Miocene episode (c. $10 \mathrm{Ma}$ ) in North-East Greenland, reflecting cooling due to uplift and erosion of the continental margin and development of the modern-day topography.

AFTA data from Herluf Trolle Land consistently define Miocene palaeotemperatures around $50^{\circ} \mathrm{C}$ at sea level, corresponding to burial below a $1.5 \mathrm{~km}$ thick rock column $\left(30^{\circ} \mathrm{C} / \mathrm{km}, 5^{\circ} \mathrm{C}\right.$ at the surface). Miocene palaeotemperatures in samples from northern Peary Land and from Kronprins Christian Land are less well constrained but are nonetheless consistent with a similar value. The failure to resolve the Miocene event at locations away from the northern coasts may indicate that Miocene 
A Deposition of

Carboniferous sediments

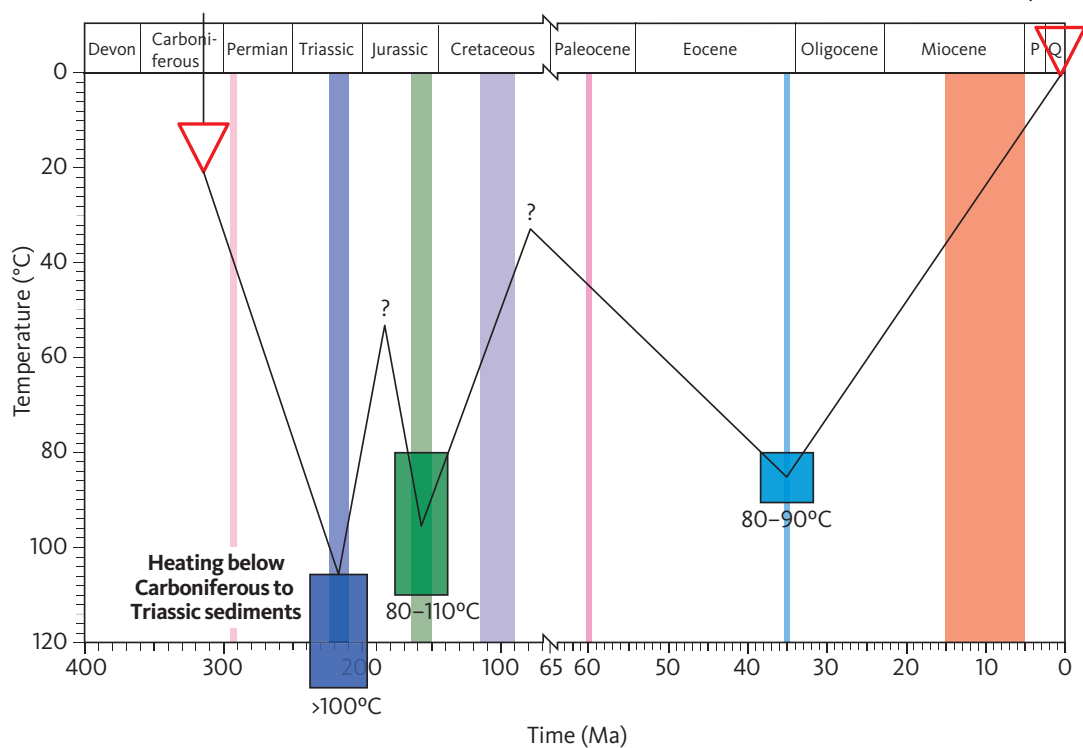

B Deposition of Lower Triassic sediments

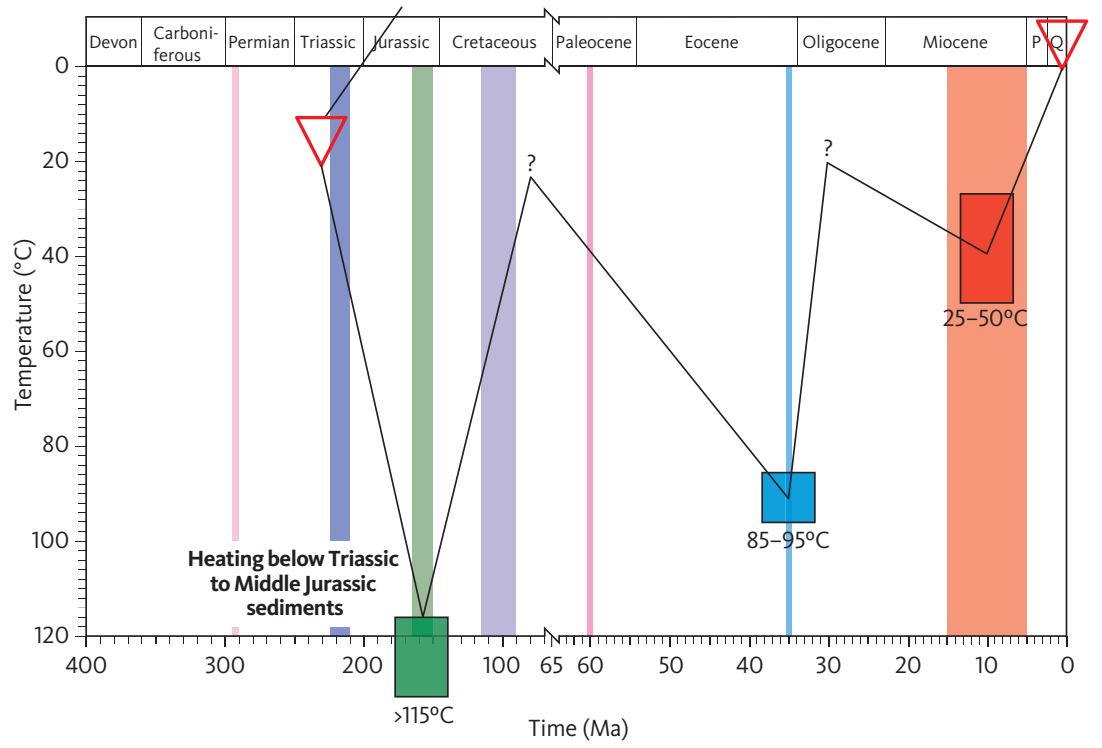

Fig. 18 Thermal history diagrams illustrating the heating and cooling (burial and exhumation) of four samples that provide stratigraphic constraints on the age of removed sections. A: GC1113-18 (20 m a.s.I.) of upper Carboniferous Kap Jungersen $\mathrm{Fm}$ exposed on Holm Land. The sample reached a palaeotemperature above $100^{\circ} \mathrm{C}$ prior to Late Triassic cooling. This palaeotemperature corresponds to burial below a cover of Carboniferous to Triassic sediments, with a thickness exceeding $2.7 \mathrm{~km}$. B: GC1113-22 $(200 \mathrm{~m}$ a.s.l.) of Lower Triassic Parish Bjerg Fm exposed on Herluf Trolle Land. The sample reached a palaeotemperature above $115^{\circ} \mathrm{C}$ prior to Late Jurassic cooling, corresponding to burial below a cover of Triassic to Middle Jurassic sediments with a thickness exceeding $3.1 \mathrm{~km}$. The conversion of palaeotecmperatures to burial depths is based on an assumed palaeogeothermal gradient of $30^{\circ} \mathrm{C} / \mathrm{km}$ and palaeosurface temperatures of $10^{\circ} \mathrm{C}$ for the end-Eocene episode and $20^{\circ} \mathrm{C}$ for earlier episodes. Red triangles: constraints for conditions at the surface during deposition of sediments or at the present day. Coloured boxes: constraints from AFTA on palaeotemperature prior to cooling (the width of the boxes is fixed for better overview). Boxes extend below the $x$-axis of the diagram where only a lower limit of the palaeotemperature is known (e.g. $>110^{\circ} \mathrm{C}$ ). Sample locations in Fig. 6. palaeotemperatures were lower than, for example, on Herluf Trolle Land. Figure 19 shows a three-dimensional elevation model of the region around Independence Fjord and illustrates that Independence Fjord is incised below a low-relief surface at just above $1 \mathrm{~km}$ a.s.l., in contrast to the more elevated and dissected alpine relief further north on Peary Land. Incision below that low-relief surface would result in cooling of rocks now near the sea level by $<50^{\circ} \mathrm{C}$, suggesting that the Miocene palaeotemperatures may reflect cooling due to the incision of the present-day relief following Miocene uplift. This contradicts the suggestion that Neogene uplift and erosion of the Wandel Sea Basin were very limited (Stemmerik et al. 1998).

\section{Discussion}

The climax of the Eurekan Orogeny is agreed to have occurred in the Eocene (Steel et al. 1985; Piepjohn et al. 2016), but both the onset and the end of the Orogeny have been a matter of debate. Here, we apply AFTA data to place tighter constraints on the timing of these events. We also address the origin of the extreme heat recorded at Nakkehoved on the northern coast of Kronprins Christian Land and comment on the likely former extent of the Wandel Sea Basin.

\subsection{Mid-Paleocene onset of the Eurekan Orogeny} We have demonstrated that cooling and exhumation along the HFFZ and the TLFZ (including Kilen) began 

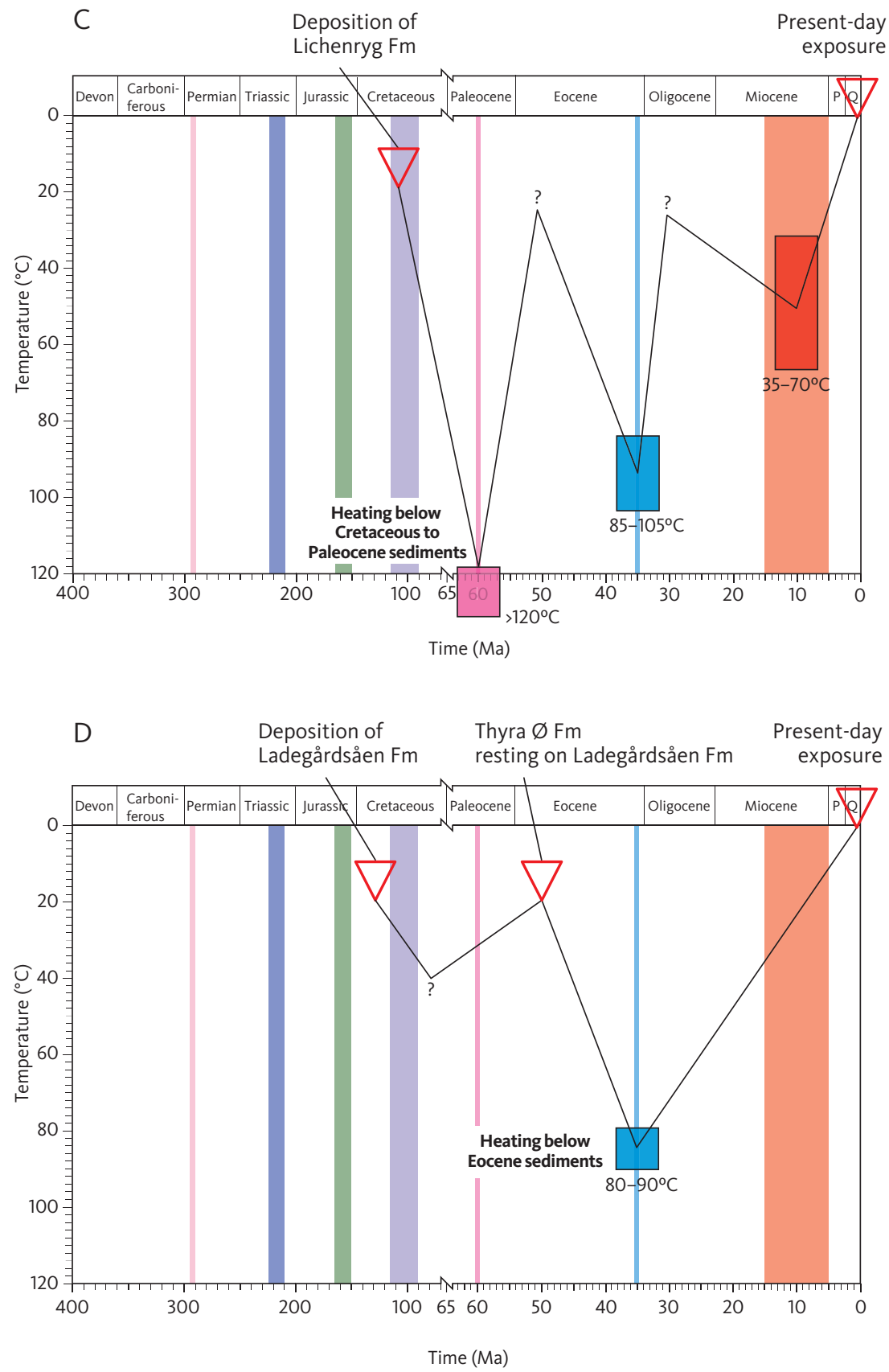

Fig. 18 (Continued) C: GC1113-58 (264 m a.s.I.) of Lower Cretaceous Lichenryg Fm exposed in Kilen. The sample reached a palaeotemperature above $120^{\circ} \mathrm{C}$ prior to Paleocene cooling, corresponding to burial below a cover exceeding a thickness of $3.3 \mathrm{~km}$ of Cretaceous to Paleocene sediments. D: GC1113-10 (23 m a.s.l.) of Lower Cretaceous sediments of the Ladegårdsåen $\mathrm{Fm}$ exposed at Kap Rigsdagen below a thin cover of the Prinsesse Thyra $\varnothing$ Formation of early to middle Eocene age (Piasecki et al. 2018). The palaeotemperature of $80-90^{\circ} \mathrm{C}$ for the Lower Cretaceous sediments prior to end-Eocene exhumation reflects heating below a thick cover of Eocene sediments at this location. This range of palaeotemperatures corresponds to burial below 2.3-2.7 km of Eocene sediments. The conversion of palaeotecmperatures to burial depths is based on an assumed palaeogeothermal gradient of $30^{\circ} \mathrm{C} / \mathrm{km}$ and palaeosurface temperatures of $10^{\circ} \mathrm{C}$ for the end-Eocene episode and $20^{\circ} \mathrm{C}$ for earlier episodes. Red triangles: constraints for conditions at the surface during deposition of sediments or at the present day. Coloured boxes: constraints from AFTA on palaeotemperature prior to cooling (the width of the boxes is fixed for better overview). Boxes extend below the $x$-axis of the diagram where only a lower limit of the palaeotemperature is known (e.g. $>110^{\circ} \mathrm{C}$ ). Sample locations in Fig. 6 . during the mid-Paleocene episode (c. $60 \mathrm{Ma}$ ), and a similar timing is likely for the region between the KCFZ and HFFZ, northern Peary Land. This episode, therefore, likely defines the onset of compression along these fault zones. We follow the interpretation of Pedersen et al. (2018) that the high palaeotemperatures in the southern part of Kilen were reached during maximum burial, prior to basin inversion, during a strong compressional event that we thus date as mid-Paleocene in age. The Paleocene timing of the compressional event is consistent with the assertion of Håkansson \& Pedersen (2015 and earlier studies) that the compressional tectonics in the Wandel Sea Basin, the Kronprins Christian Land Orogeny, occurred around the Cretaceous-Palaeogene boundary. The onset of compression in the Wandel Sea Basin coincides with the mid-Paleocene onset of sea-floor spreading in the Labrador Sea and thus with the start of movement of Greenland towards the east-northeast (Oakey \& Chalmers 2012). This implies that the mid-Paleocene compression of the Wandel Sea Basin took place during the first stage of the Eurekan Orogeny.

The relationship between the undeformed Palaeogene strata and the heavily deformed Upper Cretaceous strata in the fault zones in the Wandel Sea Basin is not known from outcrops. It is thus possible that the deformation continued in the fault zones during the deposition of the Palaeogene sediments. It has been suggested 
that deformation at Kap Washington in the western part of the Wandel Sea Basin continued into the Eocene, as the Ar-Ar system of the Kap Washington Group was partially reset in the early Eocene (c. $47 \mathrm{Ma}$; Tegner et al. 2011). However, the Ar-Ar age spectra do not show well-defined plateaus, and the resulting ages should perhaps be treated with caution.

Jones et al. (2017) used U-Pb zircon dates from tephra layers close to the base-Paleocene unconformity of the CTB on the island of Spitsbergen (in the Svalbard archipelago) to define the onset of basin formation there as mid-Paleocene, c. 61.8 Ma. Jones et al. (2017) also linked the formation of the CTB to the initiation of compression between eastern North Greenland and Svalbard, and they argued that the cessation of the Kap Washington volcanism around that time was corroborating evidence. Had there been extension between these regions, then the activity would likely have increased (Jones et al. 2017; Fig. 5). Thus, the formation of the CTB on Spitsbergen began at about the same time as the compression in the Wandel Sea Basin, slightly prior to $60 \mathrm{Ma}$ and prior to the deposition of the late Paleocene to earliest Eocene Thyra $\varnothing$ Formation. Interestingly, the CTB only received sediments from only eastern source areas during the Paleocene, and the basin received sediments only from the west after the earliest Eocene emergence of the West Spitsbergen Fold Belt (Dallmann et al. 2015; Petersen et al. 2016).

The mid-Paleocene timing for the onset of the compressional event is comparable with the late Paleocene early Eocene timing suggested by Døssing et al. (2010) and Svennevig et al. (2016) but differs from the Eocene timing suggested by von Gosen \& Piepjohn (2003). However, according to von Gosen \& Piepjohn (2003) and Svennevig et al. (2016), a late Paleocene or even Eocene north-south compression of the Wandel Sea Basin would agree with a unified timing of Eurekan deformation extending from the Canadian Arctic Archipelago to North Greenland and Svalbard. However, the Eurekan deformation occurred in two stages, as discussed in Section 2.2. During the first (Paleocene) Eurekan stage, the south-south-west to north-north-east movement of Greenland relative to Svalbard gave rise to compression that caused exhumation in the Wandel Sea Basin and subsidence of the CTB during its formation as a foreland basin. During the second (Eocene) Eurekan stage, compression continued, but the Greenland Plate changed trajectory resulting in sinistral strike-slip transpression between Greenland and Svalbard. Much of what can be seen today in the field is the final result of north-south transpression during the second Eurekan stage.

Independent lines of evidence support a mid-Paleocene onset of the Eurekan Orogeny. The Sverdrup Basin in the north-eastern Canadian Arctic Archipelago underwent a drastic change in the earliest Paleocene when the basin began to deform, coincident with the onset of sea-floor spreading west of Greenland (Embry \& Beauchamp 2019). Using apatite fission-track data, Arne et al. (2002) reported significant Paleocene cooling in the Sverdrup Basin, and Green \& Duddy (2010) reported the onset of extensive cooling in the Paleocene between 60 and $55 \mathrm{Ma}$ in Alaska, Arctic Canada, the northern Barents Sea and Svalbard based on AFTA data. The plate reconstructions published by Müller et al. (2016) showed that transpression with $18^{\circ}$ convergence between the Barents margin and North Greenland was initiated in the late Paleocene (60 Ma) and culminated in the early Eocene (54-50 Ma; Svennevig et al. 2016).

We conclude that the mid-Paleocene episode of cooling and exhumation (c. $60 \mathrm{Ma}$ ) along the major fault zones in the Wandel Sea Basin reflects the onset of the Eurekan Orogeny due to the convergence between Greenland and the Barents margin.

\subsection{Recent results from Arctic Canada}

Recent apatite fission-track and apatite (U-Th-Sm)/He data from a suite of samples from the Pearya terrane in northern Ellesmere Island (analogous to Area 1 of this study; Fig. 6) yielded fission-track ages of c. 40-50 Ma over an elevation range of c. 1600 m (Vamvaka et al. 2019). He-ages in individual grains showed a much wider range, from which the authors selected certain values to derive thermal history constraints. The logic behind this selection is not clear, as the ages show no relationship with either equivalent $U$ content or grain size, as required by the models used to interpret these data (see Green \& Duddy [2012] for discussion). From the combination of AFTA and He data, they presented a preferred scenario with three periods of cooling, showing a close correspondence with the three episodes defined on independent grounds by Piepjohn et al. (2016). This differs significantly from the preferred thermal history synthesis for Wandel Sea Basin presented here, in which major cooling occurred at c. 60 and 35 Ma. However, we noted from the supplementary information presented by Vamvaka et al. (2019) that their solutions were constrained to begin cooling from temperatures of 140$160^{\circ} \mathrm{C}$ between 60 and $50 \mathrm{Ma}$, which is consistent with the Paleocene cooling episode defined from AFTA in this study.

It, therefore, seems likely that Paleocene cooling in the two areas has a common, tectonic origin, although Vamvaka et al. (2019) considered it to have a non-tectonic origin. On comparing our data with those of Vamvaka, it seems unlikely that their data could independently define three cooling episodes between 55 and 35 Ma. Instead, we believe that a more reasonable interpretation would be two major cooling episodes, which began 
about 60 and $35 \mathrm{Ma}$, as in North Greenland, suggesting a similar tectonic evolution in both North Greenland and Ellesmere Island.

\subsection{End-Eocene tectonics in relation to the Eurekan Orogeny}

There is a clear offset in end-Eocene palaeotemperatures across the HFFZ (Fig. 11E). Typical palaeotemperatures correspond to burial below a cover of c. $3.5 \mathrm{~km}$ and c. $2.5 \mathrm{~km}$ a.s.l. on the northern and the southern side of the fault, respectively (c. $110^{\circ} \mathrm{C}$ and $85^{\circ} \mathrm{C}$ at sea level; $30^{\circ} \mathrm{C} / \mathrm{km}, 10^{\circ} \mathrm{C}$ at the surface). This implies that the rocks on the northern side of the fault were more deeply buried by about $1 \mathrm{~km}$, compared with those south of the fault, prior to end-Eocene exhumation.

The present-day summit level on both sides of the HFFZ is about $1.8 \mathrm{~km}$ a.s.I., corresponding broadly to the thickness of the cover needed to explain Miocene palaeotemperatures of $c .60^{\circ} \mathrm{C}$ at sea level on both sides of the fault, as defined by AFTA from the high mountains north of the fault zone and from Herluf Trolle Land (Section 5.2.3). Based on the landscape development in North-East Greenland, we suggest that the summit level in this study area of up to $2 \mathrm{~km}$ a.s.l. represents a peneplain that was graded to near sea level after end-Eocene exhumation and uplifted to the level of the present-day summits after c. 10 Ma (Bonow \& Japsen 2021; Japsen et al. in press). The present-day relief was, therefore, likely shaped by differential uplift and subsequent incision below this peneplain since the late Miocene. The digital elevation model shown in Fig. 19 illustrates the variation of the relief across south-eastern Peary Land to the south of the HFFZ. The constant summit level across the HFFZ implies that there was no significant vertical movement along the fault during the mid-late Miocene tectonic episode, and thus, that the offset of end-Eocene palaeotemperatures is due to differential vertical movements across the HFFZ that had taken place by the end of the Eocene.

North-south compression affected northern Peary Land in post-Santonian times, with reverse faulting at the HFFZ and thrusting along the KCTZ, which Piepjohn \& von Gosen (2001) attributed to the Eurekan Orogeny. However, they also argued that compression along the HFFZ was terminated by the change in plate-tectonic configuration at C13 time (c. $35 \mathrm{Ma}$ ), when Greenland became part of the North American Plate.

Our AFTA data document kilometre-scale, reverse movements along the HFFZ, which is consistent with the north-south reverse and thrust faults observed by Piepjohn \& von Gosen (2001). However, the results of this study also show that the inversion of the HFFZ took place in two episodes that began (1) during the mid-Paleocene (c. $60 \mathrm{Ma}$ ) and (2) at the end of the Eocene (c. $35 \mathrm{Ma}$ ). The first episode represents the onset of the Eurekan Orogeny, while the second episode represents post-Eurekan tectonics as the Greenland Plate had become part of the North American Plate. Consequently, the Eurekan Orogeny had terminated by the end of the Eocene (as supported by Piepjohn \& von Gosen 2001), and the reverse faulting along the HFFZ that occurred at that time is, therefore, unrelated to the Eurekan Orogeny.

While the end-Eocene cooling and exhumation began after the termination of spreading in the Labrador Sea, and hence after the Eurekan Orogeny, it also coincides with an important phase of plate reorganisation in North-East Atlantic (Gaina et al. 2009, 2017). The episode of uplift and erosion in North Greenland that began at the end of the Eocene is synchronous with episodes of exhumation in East and West Greenland, far from the Eurekan Orogen (Section 5.2.2). Many other observations show that significant tectonic changes affected Greenland and adjacent Arctic regions around the Eocene-Oligocene transition. For example, late Eocene magmatic activity affected the East Greenland margin (Larsen et al. 2014). Uplift of the inner margin of South-East Greenland resulted in a strong flux of coarse clastic turbidites during the late Oligocene on the shelf, above a middle Eocene - upper Oligocene hiatus (Larsen et al. 1994). End-Eocene tectonic uplift led to the formation of regional peneplains on both sides of Greenland during the Oligocene and Miocene time (Japsen et al. in press). End-Eocene exhumation affected Arctic regions beyond Greenland, including the Sverdrup Basin, Canada, as well as the Barents Sea, Svalbard and the north slope of Alaska (Green \& Duddy 2010; Embry \& Beauchamp 2019).

All these observations reveal that a deep-rooted, tectonic process began in the North-East Atlantic at the end of the Eocene after the Eurekan Orogeny. Further studies, including geodynamic modelling, are needed to investigate the origin of these post-Eurekan, tectonic changes.

\subsection{The extreme heating recorded at Nakkehoved}

VR data from around Nakkehoved, on the north coast of Kronprins Christian Land, document an extreme degree of heating of Upper Cretaceous sediments to palaeotemperatures $>250^{\circ} \mathrm{C}$ within a very limited area (Fig. 12). This extreme heating stands in stark contrast to much lower values $\left(80-90^{\circ} \mathrm{C}\right)$ in surrounding areas, and to date, no convincing explanation has been offered for these high temperatures. Nonetheless, they are thought to have occurred post-Paleocene (Håkansson \& Pedersen 2001, 


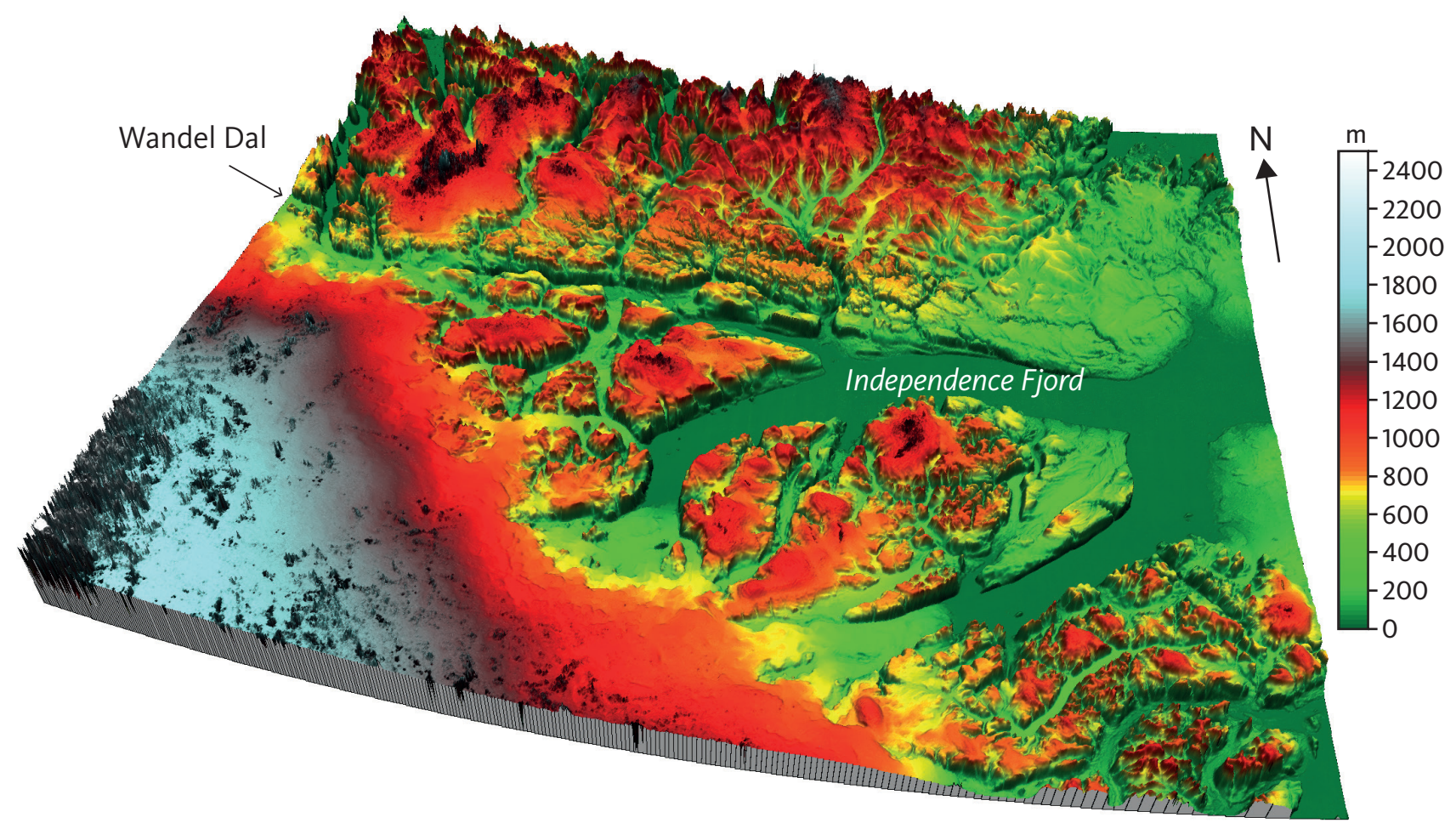

Fig. 19 3D-elevation model of the region around Independence Fjord (GLOBE 1999; map location in Fig. 3). Note that Independence Fjord and Wandel Dal (valley in Danish) are incised below a low-relief surface at about $1 \mathrm{~km}$ a.s.l. This is in contrast to more elevated and dissected, alpine relief north-west of Independence Fjord. The width of the diagram is about $250 \mathrm{~km}$. Illustration: Johan M. Bonow.

2015; Paech \& Estrada 2018). For example, Håkansson \& Pedersen (2001) differentiated between (1) the compressional tectonics of the Kronprins Christian Land Orogeny that culminated at the Cretaceous-Palaeogene boundary (corresponding to the mid-Paleocene episode of exhumation defined here) and (2) a post-Paleocene thermal event. These authors argued that the latter event was responsible for the elevated VR value of the tectonically undeformed sediments of the Thyra $\varnothing$ Formation on Prinsesse Margrethe $\varnothing$, as well as for the extreme VR values around Nakkehoved.

AFTA data from most samples analysed from around Nakkehoved and Kilen show evidence of Paleocene cooling from elevated temperatures. However, whether the palaeotemperatures on Kilen were as high as those responsible for the VR levels of up to $7 \%$ or more around Nakkehoved is not certain. The extreme palaeotemperatures may have been reached before $60 \mathrm{Ma}$, as AFTA data from Nakkehoved and Kilen provide only minimum palaeotemperature estimates for this time. However, as the event affected Upper Cretaceous sediments, it may thus have happened in Late Cretaceous or Paleocene times.

Given the complexity of the region around Nakkehoved, additional sampling for AFTA and VR, combined with detailed stratigraphic and sedimentological studies is required before the cause of the extreme thermal imprint there can be understood.

\subsection{Previous extent of the Wandel Sea Basin}

Substantial thicknesses of sediments of Carboniferous to Palaeogene age have been present within the present-day outline of the Wandel Sea Basin and outside the relatively narrow Late Cretaceous rift zones (Fig. 20). The kilometre-scale thickness of these now removed sedimentary covers implies that they must have extended substantial distances beyond the present-day outline of the Wandel Sea Basin. When we consider the reconstructed geographical positions of Carboniferous-Palaeogene basins in North-East Greenland, Svalbard and the Barents Shelf prior to Cenozoic sea-floor spreading (Gion et al. 2017), it is likely that the Wandel Sea Basin was at times coherent with them.

Several authors have highlighted the marked similarities among the sedimentary sequences in these three regions (Håkansson \& Stemmerik 1989; Mørk et al. 1989; von Gosen \& Piepjohn 2003). Håkansson \& Stemmerik (1984) presented evidence for a parallel development of the Wandel Sea Basin with Svalbard and the Barents Shelf. They found that the depositional environments of the Wandel Sea Basin in the Carboniferous to Triassic and in the Paleocene compared well with known stratigraphy in Svalbard, whereas the late Mesozoic history of the two areas showed major differences. In particular, the presence of thick Upper Cretaceous sequences in North Greenland constitutes the most conspicuous 
difference from Svalbard, where sediments of that age are absent (Dallmann et al. 2015). A study of the late Palaeozoic in the North Atlantic found evidence for a change in the overall depositional environment of the North Greenland - Barents Sea area from extensive, humid flood plains in the early Carboniferous, to shallow warm seas in the mid-Carboniferous to mid-Permian, and cooler, possibly deeper marine environments in the late Permian (Stemmerik 2000). In East Greenland, non-marine conditions prevailed during the entire Carboniferous and, following a prolonged, early Permian hiatus, warm-water carbonates were deposited during the late Permian. Stemmerik (2000) concluded that the changes reflect large-scale shifts in palaeoclimatic and subsidence patterns related to the northward drift of the area and ongoing rifting in the region. Stemmerik \& Worsley (2005) correlated the late Palaeozoic stratigraphy across North Greenland, Svalbard and the Barents Shelf, and found evidence for regional, mid-late Carboniferous uplift and erosion and local, Permian uplift and erosion.

For a long time, it was difficult to correlate the Mesozoic succession both within the Wandel Sea Basin and with basins in surrounding areas (Dypvik et al. 2002; Håkansson \& Pedersen 2015). However, a new JurassicCretaceous lithostratigraphy for Kilen by Hovikoski et al. (2018) showed correlations between Kilen and NorthEast Greenland, Svalbard and the Barents shelf. A Triassic lithostratigraphy for the Wandel Sea Basin presented evidence of a shallow shelf to deep shelf or basin floor transect that forms an outcrop analogue to contemporaneous intervals in the western Barents Sea basins and the offshore Danmarkshavn Basin (Bjerager et al. 2019). These observations support the suggestion that the now isolated components of the Wandel Sea Basin were once parts of a more extensive depositional system.

\section{Conclusions}

The results of this study reveal a long history of episodic burial and exhumation across the Wandel Sea Basin.

The earliest episode recognised is a phase of early Permian uplift and erosion that led to the formation of the basin-wide hiatus between the upper Permian and upper Carboniferous strata. The exhumation removed $2-3 \mathrm{~km}$ of rocks across the basin, including a cover of Silurian to Carboniferous sediments on Herluf Trolle Land.

Late Triassic uplift and erosion, which is likely to have affected the entire basin, led to formation of a hiatus between the Upper and Middle Triassic formations on Herluf Trolle Land when kilometre-scale thick covers of sediments were removed, including a cover of more than $2.7 \mathrm{~km}$ of upper Carboniferous to Triassic sediments on Holm Land.

Late Jurassic uplift and erosion probably affected the entire basin and led to formation of a hiatus between the Upper Jurassic and Upper Triassic strata involving removal of kilometre-thick sedimentary covers, for

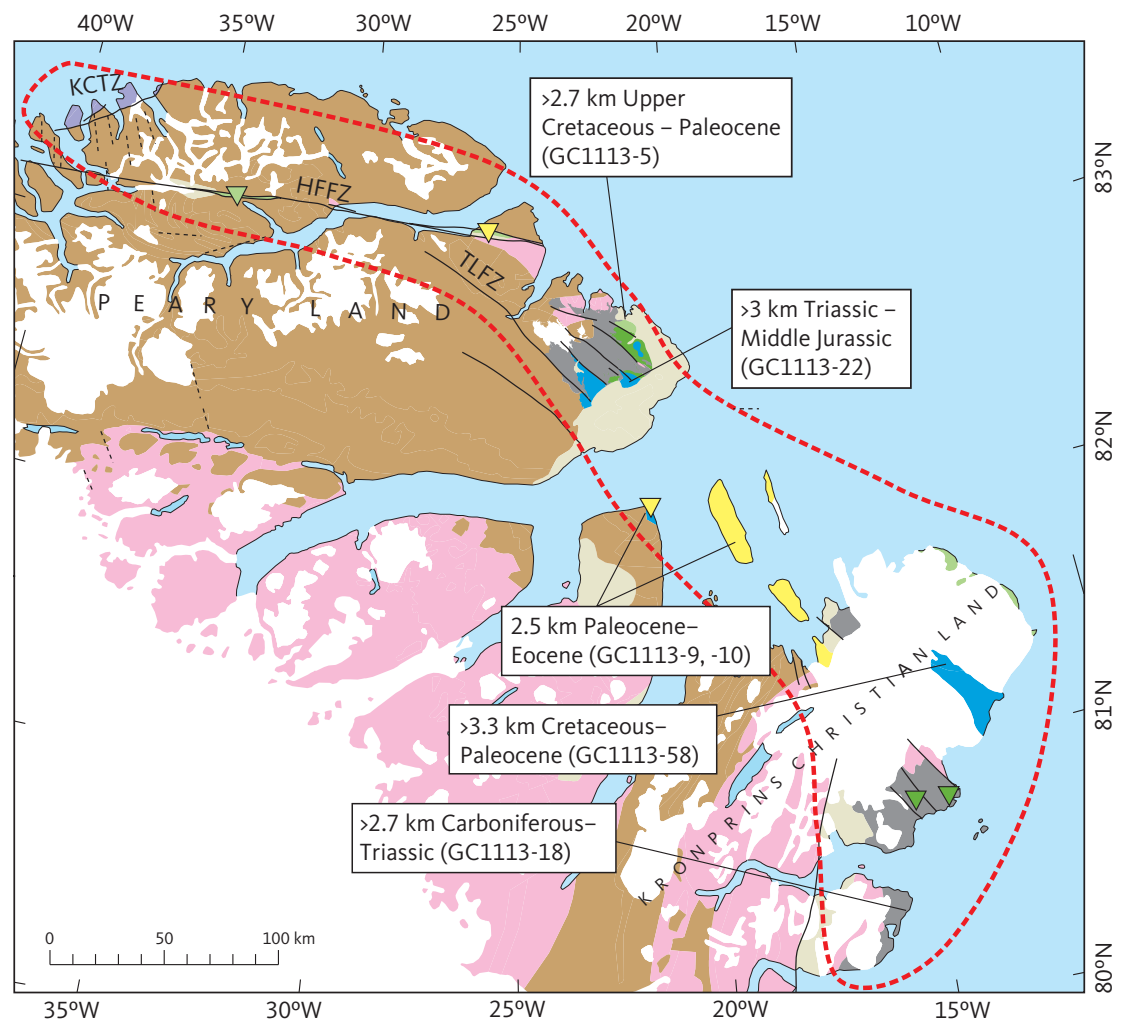

--- Present extent of the Carboniferous-Palaeogene deposits of the Wandel Sea Basin
Fig. 20 Present-day outline of the Carboniferous-Palaeogene Wandel Sea Basin compared with estimated thicknesses of removed covers (Fig. 18) Substantial thicknesses of sediments of Mesozoic and Palaeogene age have been present within the present outline of the basin, implying that they extended beyond the present-day outline of the Wandel Sea Basin. The conversion of palaeotemperatures to burial depths is based on an assumed palaeogeothermal gradient of $30^{\circ} \mathrm{C} / \mathrm{km}$ and palaeosurface temperatures of $10^{\circ} \mathrm{C}$ for the end-Eocene episode and $20^{\circ} \mathrm{C}$ for earlier episodes. HFFZ: Harder Fjord Fault Zone. KCTZ: Kap Canon Thrust Zone. TLFZ: Trolle Land Fault Zone. Geology legend and symbols defined in Fig. 4. 
example, more than $3 \mathrm{~km}$ of Triassic to Middle Jurassic sediments on Herluf Trolle Land.

Mid-Cretaceous cooling is identified in only one sample within the Wandel Sea Basin, but this episode is contemporaneous with regional exhumation in North-East Greenland. We, therefore, suggest that both areas were affected by exhumation at this time, corresponding to the Aptian to Turonian hiatus on Herluf Trolle Land.

Mid-Paleocene cooling and exhumation define the timing of compression along the major fault zones (e.g. the Kronprins Christians Lands Orogeny). A cover of more than $3 \mathrm{~km}$ of Upper Cretaceous to Paleocene sediments was present on the north coast of Kronprins Christian Land prior to the Paleocene exhumation. We thus agree with previous interpretations that the high thermal maturities in the southern part of Kilen reflect maximum burial prior to basin inversion. We conclude that the mid-Paleocene inversion of the major fault zones in the Wandel Sea Basin took place during the first stage of the Eurekan Orogeny after the onset of sea-floor spreading west of Greenland.

AFTA data from most samples analysed from the northern part of Kronprins Christian Land show evidence of Paleocene cooling, including samples from around Nakkehoved where Upper Cretaceous rocks show extreme maturities. Cooling from the extreme heating must have occurred in Late Cretaceous or Paleocene times, as AFTA data define only minimum estimates of the maximum paleotemperature. Given the complexity of the region around Nakkehoved, additional sampling for AFTA and VR combined with stratigraphic and sedimentological studies is required before the cause of the extreme thermal imprint there can be understood.

Regional exhumation of the Wandel Sea Basin began at the end of the Eocene and led to removal of most of the kilometre-thick sedimentary cover that had been deposited during Eocene subsidence. Peary Land, north of the HFFZ, was uplifted about $1 \mathrm{~km}$ more than the area south of the fault during this episode, suggesting a tectonic offset. The regional denudation and reverse faulting that began at the end of the Eocene took place after sea-floor spreading west of Greenland had ended and thus post-date the Eurekan Orogeny.

The results of this study thus define two distinct episodes of Palaeogene cooling and exhumation across the Wandel Sea Basin: (1) mid-Paleocene cooling identified mainly in inverted fault zones and (2) cooling that began at the end of the Eocene, which affected a wide area and reflects regional exhumation following deeper burial.

Mid-late Miocene cooling is identified from AFTA data in near-coastal locations. This episode coincides with a phase of late Miocene uplift and incision that initiated the formation of the present-day landscape in West and North-East Greenland. Miocene palaeotemperatures in the present study area are thus likely to reflect a similar development.

The preserved sedimentary sequences of the Wandel Sea Basin represent remnants of once much thicker strata removed in separate exhumation episodes. The thicknesses of these sedimentary covers imply that they must have extended substantially beyond the present-day boundary of the basin. The Wandel Sea Basin may, thus, at times have been coherent with the Carboniferous-Palaeogene basins in North-East Greenland, Svalbard and the Barents Sea.

\section{Acknowledgements}

Many colleagues from the Geological Survey of Denmark and Greenland (GEUS) and from the University of Copenhagen contributed with samples to this study, more than we can list here. Niels Henriksen (Oscar) provided invaluable help in retrieving samples collected in the past few decades from GEUS' core store. John R. Hopper, Kristian Svennevig and Morten Bjerager kindly provided with comments on the manuscript. Reviewers Andrew Carter and Eckart Håkansson provided constructive comments in the manuscript.

\section{Additional information}

Funding

This research work was funded by a consortium of oil companies and GEUS.

\section{Competing interests}

The authors declare no competing interests.

Author contributions

PJ: Conceptualisation, Funding acquisition, Data curation, Investigation, Writing - review \& editing.

PFG: Formal analysis, Methodology, Investigation, Writing - review \& editing

JAC: Investigation, Writing - review \& editing.

Additional files

Two supplementary files are available at $h$ ttps://doi.org/10.22008/FK2/ VLO6NQ

\section{References}

Alsen, P. McRoberts, C., Svennevig, K., Bojesen-Koefoed, J., Hovikoski, J. \& Piasecki, S. 2017: The Isrand Formation: a Middle Triassic Daonella-bearing, black shale unit in Kilen, North Greenland (with a note on the Triassic in Amdrup Land). Newsletters on Stratigraphy 50, 31-46. https://doi.org/10.1127/nos/2016/0341

Armstrong, H., Smith, M., Aldridge, R. \& Tull, S. 1994: Thermal maturation of the Lower Palaeozoic strata of northern Greenland from conodont colour alteration index (CAI) data: implications for burial history and hydrocarbon exploration. Geological Magazine 131, 219-230. https:// doi.org/10.1017/S0016756800010748

Arne, D., Grist, A., Zentilli, M., Collins, M., Embry, A. \& Gentzis, T. 2002: Cooling of the Sverdrup Basin during Tertiary basin inversion: implications for hydrocarbon exploration. Basin Research 14, 183-205. https://doi.org/10.1046/j.1365-2117.2002.00163.x

Bjerager, M., Alsen, P., Hovikoski, J., Lindström, S., Stemmerik, L. \& Therkelsen, J. 2019: Triassic lithostratigraphy of the Wandel Sea Basin, North Greenland. Bulletin of the Geological Society of Denmark 67, 83-105. https://doi.org/10.37570/bgsd-2019-67-06 
Bonow, J.M. \& Japsen, P. 2021: Peneplains and tectonics in North-East Greenland after opening of the North-East Atlantic. GEUS Bulletin 45(1), 5297. https://doi.org/10.34194/geusb.v45.5297

Boyd, A. 1990: The Thyra $\varnothing$ flora: toward an understanding of the climate and vegetation during the early tertiary in the high arctic. Review of Palaeobotany and Palynology 62, 189-203. https://doi. org/10.1016/0034-6667(90)90089-2

Boyd, A., Håkansson, E. \& Stemmerik, L. 1994: Preliminary age considerations and descriptions of the Early Tertiary Thyra $\varnothing$ flora from eastern North Greenland. in: Håkansson, E. (ed): Wandel Sea Basin: Basin Analysis 15. Geological Institute, University of Copenhagen.

Brozena, J., Childers, V., Lawver, L., Gahagan, L., Forsberg, R., Faleide, J. \& Eldholm, O. 2003: New aerogeophysical study of the Eurasia Basin and Lomonosov Ridge: implications for basin development. Geology 31, 825-828. https://doi.org/10.1130/G19528.1

Burnham, A.K. \& Sweeney, J.J. 1989: A chemical kinetic model of vitrinite maturation and reflectance. Geochimica et Cosmochimica Acta $\mathbf{5 3}$ 2649-2657. https://doi.org/10.1016/0016-7037(89)90136-1

Chalmers, J.A. \& Pulvertaft, T.C.R. 2001: Development of the continental margins of the Labrador Sea: a review. In: Wilson, R.C.L., Withmarsh, R.B., Taylor, B. \& Froitzheim, N. (eds): Non-volcanic rifting of continental margins: a comparison of evidence from land and sea. Geological Society London, Special Publications 187, 77-105. https://doi. org/10.1144/gsl.sp.2001.187.01.05

Croxton, C.A., Dawes, P.R., Soper, N.J. \& Thomsen, E. 1980: An occurrence of Tertiary shales from the Harder Fjord Fault, North Greenland fold belt, Peary Land. Rapport Grønlands Geologiske Undersøgelse 101, 61-64.

Dallmann, W. 2015: Geoscience Atlas of Svalbard: Norsk Polarinstitutt. 292 pp.

Dallmann, W.K., Andresen, A., Bergh, S.G., Maher jr., H.D. \& Ohta, Y. 1993: Tertiary fold-and-thrust belt of Spitsbergen, Svalbard. Norsk Polarinstitutt Meddelelser 128, 48 pp., 3 maps.

Dam, G., Larsen, M. \& Sørensen, J.C. 1998: Sedimentary response to mantle plumes: implications from Paleocene onshore successions, West and East Greenland. Geology 26, 207-210. https://doi.org/10.113 0/0091-7613(1998)026\%3C0207:SRTMPI\%3E2.3.CO;2

Dawes, P.R. 1976: Precambrian to Tertiary of northern Greenland. In: Escher, A. \& Watt, W.S. (eds): Geology of Greenland, 248-303. Copenhagen: The Geological Survey of Greenland.

Dawes, P.R. \& Soper, N. 1973: Pre-quaternary history of North Greenland: Regional Arctic geology of the Nordic countries. In: Pitcher, M.G. (ed): Arctic Geology: AAPG Memoir 19, 117-134.

De Paor, D.G., Bradley, D.C., Eisenstadt, G. \& Phillips, S.M. 1989: The Arctic Eurekan orogen: A most unusual fold-and-thrust belt. Geological Society of America Bulletin 101, 952-967. https://doi. org/10.1130/0016-7606(1989)101<0952:taeoam>2.3.co;2

Døssing, A., Jackson, H.R., Matzka, J., Einarsson, I., Rasmussen, T.M., Olesen, A.V. \& Brozena, J. 2013: On the origin of the Amerasia Basin and the High Arctic Large Igneous Province-results of new aeromagnetic data. Earth and Planetary Science Letters 363, 219-230. https:// doi.org/10.1016/j.epsl.2012.12.013

Døssing, A., Stemmerik, L., Dahl-Jensen, T. \& Schlindwein, V. 2010: Segmentation of the eastern North Greenland oblique-shear margin regional plate tectonic implications. Earth and Planetary Science Letters 292, 239-253. https://doi.org/10.1016/j.eps/.2009.12.036

Dypvik, H., Håkansson, E. \& Heinberg, C. 2002: Jurassic and Cretaceous palaeogeography and stratigraphic comparisons in the North Greenland-Svalbard region. Polar Research 21, 91-108. https://doi. org/10.1111/j.1751-8369.2002.tb00069.x

Embry, A. \& Beauchamp, B. 2019: Sverdrup Basin. In: Miall, A.D. (ed): The Sedimentary Basins of the United States and Canada, p. 559-592. Calgary, AB: Elsevier. https://doi.org/10.1016/B978-0-444-63895-3.00014-0

Escher, J.C. \& Pulvertaft, T.C.R. 1995: Geological map of Greenland, 1:2 500 000. Copenhagen: Geological Survey of Denmark.

Faleide, J.I., Tsikalas, F., Breivik, A.J., Mjelde, R., Ritzmann, O., Engen, O., Wilson, J. \& Eldholm, O. 2008: Structure and evolution of the continental margin off Norway and the Barents Sea. Episodes 31, 82-91. https://doi.org/10.18814/epiiugs/2008/v31i1/012

Gaina, C., Gernigon, L. \& Ball, P. 2009: Paleocene-recent plate boundaries in the NE Atlantic and the formation of the Jan Mayen microcontinent.
Journal of the Geological Society of London 166, 601-616. https://doi. org/10.1144/0016-76492008-112

Gaina, C., Nasuti, A., Kimbell, G.S. \& Blischke, A. 2017: Break-up and seafloor spreading domains in the NE Atlantic. In: Péron-Pinvidic, G. et al. (eds): The NE Atlantic region: a reappraisal of crustal structure, tectonostratigraphy and magmatic evolution. Geological Society, London, Special Publications 447, 12 pp. https://doi.org/10.1144/SP447.12

Galbraith, R.F. 2005: Statistics for fission track analysis, 192 pp. Boca Raton, FL: Chapman \& Hall/CRC Interdisciplinary Statistics Series.

Gallagher, K., Hawkesworth, C.J. \& Mantovani, M.S.M. 1995: Denudation, fission track analysis and the long-term evolution of passive margin topography: application to the southeast Brazilian margin. Journal of South American Earth Sciences 8, 65-77. https:// doi.org/10.1016/0895-9811(94)00042-z

Gautier, D.L. et al. 2011: Assessment of NE Greenland: prototype for development of Circum-Arctic resource appraisal methodology. In: Spencer, A.M. et al. (eds): Arctic petroleum geology. Geological Society, London, Memoirs 35, 663-672. https://doi.org/10.1144/m35.43

Gion, A.M., Williams, S.E. \& Mueller, R.D. 2017: A reconstruction of the Eurekan Orogeny incorporating deformation constraints. Tectonics 36, 304-320. https://doi.org/10.1002/2015tc004094

GLOBE Task Team et al. 1999: The global land one-kilometer base elevation (GLOBE) digital elevation model, version 1.0. National Oceanic and Atmospheric Administration. http://www.ngdc.noaa.gov/mgg/topo/ globe.html (Accessed: April 2012)

Gradstein, F.M., Ogg, J.G. \& Hilgen, F.J. 2012: On the geologic time scale. Newsletters on Stratigraphy 45, 171-188. https://doi. org/10.1127/0078-0421/2012/0020

Green, P.F. 1986. On the thermo-tectonic evolution of Northern England: evidence from fission track analysis. Geological Magazine 123, 493506. https://doi.org/10.1017/s0016756800035081

Green, P.F. 2014: Thermal history of outcrop samples from central and eastern North Greenland based on AFTA and VR. Geotrack Report GC1113, 217 pp. Victoria: Geotrack International. Available in Supplementary File S2.

Green, P.F. \& Duddy, I.R. 2010: Synchronous exhumation events around the Arctic including examples from Barents Sea and Alaska North Slope. In: Vining, B.A. \& Pickering, S.C. (eds): Petroleum geology: from mature basins to new frontiers. Geological Society, London, Petroleum Geology Conference Series 7, 633-644. https://doi.org/10.1144/0070633

Green, P.F. \& Duddy, I.R. 2012: Thermal history reconstruction in sedimentary basins using apatite fission-track analysis and related techniques. In: Analyzing the thermal history of sedimentary basins: methods and case studies. The Society of Economic Paleontologists and Mineralogists (SEPM). Special Publication 103, 65-104. https://doi. org/10.2110/sepmsp.103.065

Green, P.F., Lidmar-Bergström, K., Japsen, P., Bonow, J.M. \& Chalmers, J.A. 2013: Stratigraphic landscape analysis, thermochronology and the episodic development of elevated passive continental margins. Geological Survey of Denmark and Greenland Bulletin 30, 150 pp. https://doi.org/10.34194/geusb.v30.4673

Green, P.F., Japsen, P., Guarnieri, P. \& Nielsen, T.F.D. 2014: Thermal history of outcrop samples from South-East Greenland based on apatite fission-track analysis. In: Stensgaard, B.M. (ed): South-East Greenland Mineral Endowment Task (SEGMENT), South-East Greenland Workshop, Copenhagen, 27-28 March 2014. Abstract Volume 21-25.

Green, P.F., Duddy, I.R., Japsen, P., Bonow, J.M. \& Malan, J. 2017: Postbreakup burial and exhumation of the southern margin of Africa. Basin Research, 1-32. https://doi.org/10.1111/bre.12167

Green, P.F., Japsen, P., Chalmers, J.A., Bonow, J.M. \& Duddy, I.R. 2018: Post-breakup burial and exhumation of passive continental margins: seven propositions to inform geodynamic models. Gondwana Research 53, 58-81. https://doi.org/10.1016/j.gr.2017.03.007

Guarnieri, P. 2015: Pre-break-up palaeostress state along the East Greenland margin. Journal of the Geological Society, London 172, 727-739. https://doi.org/10.1144/jgs2015-053

Håkansson, E. \& Pedersen, S.A.S. 1982: Late Paleozoic to Tertiary tectonic evolution of the continental margin in North Greenland. Proceedings of the Third International Symposium on Arctic Geology, Canadian Society of Petroleum Geologists, Memoir 8, 331-348. 
Håkansson, E. \& Pedersen, S.A.S. 2001: The Wandel Hav Strike-Slip Mobile Belt - a Mesozoic plate boundary in North Greenland. Bulletin of the Geological Society of Denmark 48, 149-158.

Håkansson, E. \& Pedersen, S.A.S. 2015: A healed strike-slip plate boundary in North Greenland indicated through associated pull-apart basins. Geological Society, London, Special Publications 413, 143-169. https://doi.org/10.1144/sp413.10

Håkansson, E. \& Stemmerik, L. 1984: Wandel sea basin - the North Greenland equivalent to Svalbard and the Barents Shelf. In: Spencer, A.M. et al. (eds): Petroleum Geology of the North European Margin, 97-107. Dordrecht: Springer. https://doi.org/10.1007/978-94-009-5626-1_8

Håkansson, E. \& Stemmerik, L. 1989: Wandel Sea basin - a new synthesis of the late Paleozoic to Tertiary accumulation in North Greenland. Geology 17, 683-686. https://doi.org/10.1130/0091-7613(1989)017<068 3:wsbans $>2.3 . c 0 ; 2$

Håkansson, E., Heinberg, C. \& Stemmerik, L. 1991: Mesozoic and Cenozoic history of the Wandel Sea Basin area. North Greenland. Bulletin Grønlands Geologiske Undersøgelse 160, 153-164.

Håkansson, E., Piasecki, S., Konnerup-Madsen, J. \& Thomsen, E. 1994: A late, thermal event in the Wandel Sea Basin; eastern North Greenland. In: Håkansson, E. (ed): Wandel Sea Basin: Basin Analysis 22, 9 pp. Copenhagen: University of Copenhagen.

Harrison, J. 2008: Regional variation in structural style, deformation kinematics, and summary of tectonic history, northeast Ellesmere Island. Geological Survey of Canada Bulletin 592, 245-284. https://doi. org/10.4095/226147

Harrison, J.C., Mayr, U., McNeil, D.H., Sweet, A.R., Mclntyre, D.J., Eberle, J.J., Harington, C.R., Chalmers, J.A., Dam, G. \& Nohr-Hansen, H. 1999: Correlation of Cenozoic sequences of the Canadian Arctic region and Greenland; implications for the tectonic history of northern North America. Bulletin of Canadian Petroleum Geology 47, 223-254.

Henriksen, N., Higgins, A.K., Kalsbeek, F. \& Pulvertaft, T.C.R. 2009: Greenland from Archean to Quaternary. Descriptive text to the 1995 Geological map of Greenland. Geological Survey of Denmark and Greenland Bulletin 18, 126 pp. https://doi.org/10.34194/ggub.v185.5197

Higgins, A.K., Soper, N.J. \& Leslie, A.G. 2000: The Ellesmerian and Caledonian orogenic belts of Greenland. Polarforschung 68, 141-151.

Hopper, J.R. et al. (eds). 2014: Tectonostratigraphic Atlas of the NorthEast Atlantic Region, 338 pp. Copenhagen: Geological Survey of Denmark and Greenland.

Hurford, A.J. \& Green, P.F. 1983: The zeta age calibration of fission-track dating. Chemical Geology 41, 285-317. https://doi.org/10.1016/ s0009-2541(83)80026-6

Hovikoski, J., Pedersen, G.K., Alsen, P., Lauridsen, B.W., Svennevig, K., Nøhr-Hansen, H., Sheldon, E., Dybkjær, K., Bojesen-Koefoed, J. \& Piasecki, S. 2018: The Jurassic-Cretaceous lithostratigraphy of Kilen, Kronprins Christian Land, eastern North Greenland. Bulletin of the Geological Society of Denmark 66, 61-112. https://doi.org/10.37570/ bgsd-2018-66-04

Ineson, J.R., Hovikoski, J., Sheldon, E., Piasecki, S., Alsen, P., Fyhn, M.B., Bjerager, M., Dybkjær, K., Guarnieri, P. \& Lauridsen, B.W. 2020: Regional impact of Early Cretaceous tectono-magmatic uplift in the Arctic: implications of new data from eastern North Greenland. Terra Nova 00, 1-9. https://doi.org/10.1111/ter.12514

Japsen, P., Bonow, J.M., Green, P.F., Chalmers, J.A. \& Lidmar-Bergström, K. 2006: Elevated, passive continental margins: long-term highs or Neogene uplifts? New evidence from West Greenland. Earth and Planetary Science Letters 248, 330-339. https://doi.org/10.1016/j.epsl.2006.05.036

Japsen, P., Bonow, J.M., Green, P.F., Chalmers, J.A. \& Lidmar-Bergström, K. 2009: Formation, uplift and dissection of planation surfaces at passive continental margins - a new approach. Earth Surface Processes and Landforms 34, 683-699. https://doi.org/10.1002/esp.1766

Japsen, P., Green, P.F., Bonow, J.M., Bjerager, M. \& Hopper, J.R. in press: Episodic burial and exhumation in North-East Greenland before and after opening of the North-East Atlantic. GEUS Bulletin 45(2).

Jokat, W., Lehmann, P., Damaske, D. \& Nelson, J.B. 2016: Magnetic signature of North-East Greenland, the Morris Jesup Rise, the Yermak Plateau, the central Fram Strait: constraints for the rift/drift history between Greenland and Svalbard since the Eocene. Tectonophysics 691, 98-109. https://doi.org/10.1016/j.tecto.2015.12.002
Jones, M.T. et al. 2017: Constraining shifts in North Atlantic plate motions during the Palaeocene by U-Pb dating of Svalbard tephra layers. Scientific reports 7, 9 pp. https://doi.org/10.1038/s41598-017-06170-7

Larsen, H.C. et al. 1994: 13. Summary and principal results. In: Proceedings of the Ocean Drilling Program, Initial Reports 152, 279-292. College Station, TX: Ocean Drilling Program. https://doi.org/10.2973/odp. proc.ir.152.113.1994

Larsen, L.M., Pedersen, A.K., Tegner, C. \& Duncan, R.A. 2014: Eocene to Miocene igneous activity in NE Greenland: northward younging of magmatism along the East Greenland margin. Journal of the Geological Society 171, 539-553. https://doi.org/10.1144/jgs2013-118

Lyck, J.M. \& Stemmerik, L. 2000: Palynology and depositional history of the Paleocene? Thyra $\varnothing$ Formation, Wandel Sea Basin, eastern North Greenland. Geology of Greenland Survey Bulletin 187, 21-49. https:// doi.org/10.34194/ggub.v187.5193

Maher, H.D., Braathen, A., Bergh, S., Dallmann, W. \& Harland, W.B. 1995: Tertiary or Cretaceous age for Spitsbergen's fold-thrust belt on the Barents Shelf. Tectonics 14, 1321-1326. https://doi.org/10.1029/95tc01257

Mørk, A., Embry, A.F. \& Weitschat, W. 1989: 11 Triassic transgressive regressive cycles in the Sverdrup Basin. In: Collinson J.D. (ed): Correlation in Hydrocarbon Exploration, p. 113-130. Dordrecht: Springer.

Müller, R.D., et al. 2016: Ocean basin evolution and global-scale plate reorganization events since Pangea breakup. Annual Review of Earth and Planetary Sciences 44, 107-138. https://doi.org/10.1146/ annurev-earth-060115-012211

Oakey, G.N. \& Chalmers, J.A. 2012: A new model for the Paleogene motion of Greenland relative to North America: plate reconstructions of the Davis Strait and Nares Strait regions between Canada and Greenland. Journal of Geophysical Research: Solid Earth 117, 1-28. https://doi.org/10.1029/2011jb008942

Okulitch, A. \& Trettin, H. 1991: Late Cretaceous-early Tertiary deformation, Arctic Islands. Geology of the Innuitian Orogen and Arctic Platform of Canada and Greenland. Geological Survey of Canada, Geology of Canada Series 3, 469-490. https://doi. org/10.4095/133999

Paech, H.-J. \& Estrada, S. 2018: Coal rank data and tectonic structure of Mesozoic and Paleogene sediments in North Greenland. In: Piepjohn, K. et al. (eds): Tectonic Evolution of the Arctic Margins and Trans-Arctic Links with Adjacent Orogens. Geological Society of America Special Papers 541. https://doi.org/10.1130/2018.2541(10)

Pedersen, G.K., Lauridsen, B.W., Svennevig, K., Bojesen-Koefoed, J.A., Nøhr-Hansen, H. \& Alsen, P. 2018: Burial history of a folded cretaceous succession - a case study from the southern part of Kilen, eastern north Greenland. Cretaceous Research 89, 22-35. https://doi. org/10.1016/j.cretres.2018.03.007

Pedersen, S.A.S. \& Håkansson, E. 2001: Kronprins Christian Land Orogeny deformational styles of the end Cretaceous transpressional mobile belt in eastern North Greenland. Polarforschung 69, 117-130.

Petersen, T.G., Thomsen, T., Olaussen, S. \& Stemmerik, L. 2016: Provenance shifts in an evolving Eurekan foreland basin: the Tertiary Central Basin, Spitsbergen. Journal of the Geological Society London 173, 634-648. https://doi.org/10.1144/jgs2015-076

Piasecki, S., Nøhr-Hansen, H. \& Dalhoff, F. 2018: Revised stratigraphy of Kap Rigsdagen beds, Wandel Sea Basin, North Greenland. Newsletters on Stratigraphy 51, 411-425. https://doi.org/10.1127/nos/2018/0444

Piepjohn, K. \& von Gosen, W. 2001: Polyphase deformation at the Harder Fjord Fault Zone (North Greenland). Geological Magazine 138, 407434. https://doi.org/10.1017/s0016756801005660

Piepjohn, K., von Gosen, W. \& Tessensohn, F. 2016: The Eurekan deformation in the Arctic: an outline. Journal of the Geological Society, London 173, 1007-1024. https://doi.org/10.1144/jgs2016-081

Rasmussen,J.A. \& Smith, M.P. 2001: Conodont geothermometry and tectonic overburden in the northernmost East Greenland Caledonides. Geological Magazine 138, 687-698. https://doi.org/10.1017/s0016756801005908

Rasmussen, J.A.H. \& Håkansson, E. 1996: First Permo-Carboniferous conodonts from North Greenland. Geological Magazine 133, 553-564. https://doi.org/10.1017/s0016756800007834

Ricketts, B.D. 1994: Basin analysis, Eureka Sound Group, Axel Heiberg and Ellesmere Islands, Canadian Arctic archipelago. Geological Survey of Canada Memoir 439, 119 pp. https://doi.org/10.4095/194814 
Steel, R., Gjelberg, J., Helland-Hansen, W., Kleinspehn, K., Nøttvedt, A. \& Rye-Larsen, M. 1985: The Tertiary strike-slip basins and orogenic belt of Spitsbergen. In: Biddle, K.T. \& Christle-Blick, K. (eds): Strike-slip deformation, basin formation, and sedimentation. The Society of Economic Paleontologists and Mineralogists (SEPM) Special Publication 37, 339-359. https://doi.org/10.2110/pec.85.37.0339

Stemmerik, L. 2000: Late Palaeozoic evolution of the North Atlantic margin of Pangea. Palaeogeography, Palaeoclimatology, Palaeoecology 161, 95-126. https://doi.org/10.1016/s0031-0182(00)00119-x

Stemmerik, L. \& Worsley, D. 2005: 30 years on — Arctic Upper Palaeozoic stratigraphy, depositional evolution and hydrocarbon prospectivity. Norwegian Journal of Geology 85, 151-168.

Stemmerik, L., Dalhoff, F., Larsen, B.D., Lyck, J.M., Mathiesen, A. \& Nilsson, I. 1998: Wandel Sea Basin, eastern North Greenland. Geology of Greenland Survey Bulletin 180, 55-62. https://doi.org/10.34194/ggub.v180.5086

Surlyk, F. 1990: Timing, style and sedimentary evolution of Late Palaeozoic - Mesozoic extensional basins in East Greenland. In: Hardman, R.F.P. \& Brooks, J. (eds) Tectonic events responsible for Britain's oil and gas reserves. Geological Society Special Publications (London) 55, 107-125. https://doi.org/10.1144/GSL.SP.1990.055.01.05

Surlyk, F. 1991: Tectonostratigraphy of north Greenland. Bulletin Grønlands Geologiske Undersøgelse 160, 27-47.

Svennevig, K., Guarnieri, P. \& Stemmerik, L. 2016: Tectonic inversion in the Wandel Sea Basin: A new structural model of Kilen (eastern North Greenland). Tectonics 35, 2896-2917. https://doi.org/10.1002/2016TC004152
Svennevig, K., Guarnieri, P. \& Stemmerik, L. 2017: 3D restoration of a Cretaceous rift basin in Kilen, eastern North Greenland. Norwegian Journal of Geology 97, 21-32. https://doi.org/10.17850/ njg97-1-02

Svennevig, K., Alsen, P., Guarnieri, P., Hovikoski, J., Wesenberg Lauridsen, B., Krarup Pedersen, G., Nøhr-Hansen, H. \& Sheldon, E. 2018: Descriptive text to the Geological map of Greenland, 1:100 000, Kilen $81 \varnothing .1$ Syd. Geological Survey of Denmark and Greenland Map Series 8, 1-29. https://doi.org/10.34194/geusm.v8.4526

Tegner, C., Storey, M., Holm, P.M., Thorarinsson, S.B., Zhao, X., Lo, C.H. \& Knudsen, M.F. 2011: Magmatism and Eurekan deformation in the High Arctic Large Igneous Province: 40Ar-39Ar age of Kap Washington Group volcanics, North Greenland. Earth and Planetary Science Letters 303, 203-214. https://doi.org/10.1016/j.epsl.2010.12.047

Tessensohn, F. \& Piepjohn, K. 2000: Eocene compressive deformation in Arctic Canada, North Greenland and Svalbard and its plate tectonic causes. Polarforschung 68, 121-124.

Vamvaka, A., Pross, J., Monien, P., Piepjohn, K., Estrada, S., Lisker, F. \& Spiegel, C. 2019: Exhuming the top end of North America: episodic evolution of the Eurekan belt and its potential relationships to North Atlantic plate tectonics and Arctic climate change. Tectonics 38, 4207-4228. https://doi.org/10.1029/2019tc005621

von Gosen, W. \& Piepjohn, K. 2003: Eurekan transpressive deformation in the Wandel Hav Mobile Belt (northeast Greenland). Tectonics 22, 28. https://doi.org/10.1029/2001TC901040 